\title{
The Beni Bousera marbles, record of a Triassic-Early Jurassic hyperextended margin in the Alpujarrides-Sebtides units (Rif belt, Morocco)
}

\author{
Aboubaker Farah ${ }^{1}$, André Michard ${ }^{2, *}$, Omar Saddiqi ${ }^{1}$, Ahmed Chalouan $^{3}$, Christian Chopin ${ }^{4}$, \\ Pilar Montero ${ }^{5}$, Michel Corsini ${ }^{6}$ and Fernando Bea ${ }^{5}$ \\ ${ }^{1}$ Geosciences Laboratory, Faculty of Sciences Aïn Chock, Hassan II University, BP 5366, Maârif, Casablanca, Morocco \\ 2 Em. Pr. Université Paris-Sud (Orsay), 10, rue des Jeûneurs, 75002 Paris, France \\ 3 Earth Sci. Dept, Faculty of Sciences, Mohamed V University, BP 1014, Rabat-Agdal, Morocco \\ ${ }^{4}$ Laboratoire de Géologie, UMR8538, Département de géosciences, École normale supérieure - CNRS, Université PSL, 75005 Paris, \\ France \\ 5 Department of Mineralogy and Petrology, University of Granada, Campus Fuentenueva, 18002 Granada, Spain \\ ${ }^{6}$ Géoazur, Université Côte d'Azur, CNRS, IRD, Observatoire de la Côte d'Azur, UMR 7329, 250, rue Albert-Einstein, 06560 Sophia \\ Antipolis, France
}

Received: 6 May 2020 / Accepted: 18 February 2021 / Publishing online: 28 April 2021

\begin{abstract}
The timing and process of exhumation of the subcontinental peridotites of the Gibraltar Arc (Ronda, Beni Bousera) have been discussed extensively over the last decades. In this work, we contribute to this debate through the first mapping, structural and petrological analyses, and SHRIMP U-Th-Pb dating of high-grade marbles that crop out around the Beni Bousera antiform of the Alpujarrides-Sebtides units of northern Rif (Morocco). These marbles, here termed the Beni Bousera marbles (BBMs), instead of being intercalations in the granulitic envelope (kinzigites) of the Beni Bousera peridotites, as previously described, form minor, dismembered units within a $\sim 30$ to $300 \mathrm{~m}$ thick mylonitic contact between the kinzigites and the overlying gneisses of the Filali Unit (Filali-Beni Bousera Shear Zone, FBBSZ). They display silicate-rich dolomitic marbles, sandy-conglomeratic calcareous marbles and thinly bedded marble with interleaved biotite-rich schists. An unconformable contact, either of stratigraphic or tectonic origin, with the underlying kinzigites, is observed locally. Pebbles or detrital grains include K-feldspar, quartz, almandine garnet and zircon. Peak mineral assemblages consist of forsterite, $\mathrm{Mg}$-Al-spinel, geikielite $\left(\mathrm{MgTiO}_{3}\right)$, phlogopite and accessory zirconolite, baddeleyite and srilankite in dolomite marble, as well as K-feldspar, scapolite, diopside, titanite and accessory graphite and zircon in calcite marble. These assemblages characterize peak HT-LP metamorphic conditions close to $700-750{ }^{\circ} \mathrm{C}, \leq 4.5 \mathrm{kbar}$. The FBBSZ includes minor ductile thrusts that determine kinzigite horses or slivers carried $\mathrm{NW}$-ward over the marbles. Within the latter, NNEtrending folds are conspicuous. Brittle, northward-dipping normal faults crosscut the FBBSZ ductile structures. Detrital cores of zircon from the BBMs yield two U-Th-Pb age clusters of $\sim 270 \mathrm{Ma}$ and $\sim 340 \mathrm{Ma}$, whereas their rims yield $\sim 21 \mathrm{Ma}$ ages. Correlations with comparable settings in other West Mediterranean Alpine belts are discussed. The BBMs compare with the Triassic carbonates deposited over the crustal units of the Alpujarrides-Sebtides. The assumed Triassic protoliths may have been deposited onto the kinzigites or carried as extensional allochthons over a detachment in the Early Jurassic during the incipient formation of the Alboran Domain continental margin. Thus, it is concluded that the Beni Bousera mantle rocks were exhumed to a shallow depth during early rifting events responsible for the birth of the Maghrebian Tethys.
\end{abstract}

Keywords: Gibraltar Arc / mantle exhumation / Alpine Tethys / HT metamorphism / Triassic rifting / hyperextended margins / SHRIMP U-Th-Pb dating

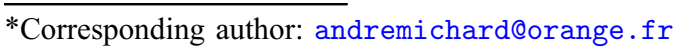




\begin{abstract}
Résumé - Les marbres des Beni Bousera, témoins d'une marge hyper-étirée triasique-liasique dans les unités Alpujarrides-Sebtides du Rif (Maroc). La chronologie et les processus d'exhumation des péridotites sous-continentales de l'Arc de Gibraltar (Ronda, Beni Bousera) ont fait l'objet de discussions nombreuses ces dernières décennies. Dans ce travail, nous contribuons à ce débat par la cartographie, l'analyse structurale, la pétrologie et la géochronologie U-Th-Pb SHRIMP des marbres de haut degré qui affleurent autour de la moitié sud-est de l'antiforme des Beni Bousera (Rif septentrional). Ces marbres des Beni Bousera (BBMs), loin d'être des intercalations dans l'enveloppe granulitique (kinzigites) des péridotites, comme admis jusqu'ici, forment de petites unités démembrées dans une zone de cisaillement ductile, épaisse de $\sim 30$ à $300 \mathrm{~m}$, entre les kinzigites et les gneiss de l'unité Filali superposée (FBBSZ). Ils comportent des bancs de carbonates dolomitiques silicatés, des bancs détritiques et conglomératiques, des lits carbonatés fins à interlits phylliteux, composant une sédimentation de plateforme. Une discordance, de nature stratigraphique ou tectonique, s'observe localement sur les kinzigites. Les galets et grains clastiques comportent feldspath potassique, quartz, grenat et zircon. Les minéraux du pic métamorphique incluent forstérite, $\mathrm{Mg}$-Al-spinelle, phlogopite, geikielite $\left(\mathrm{MgTiO}_{3}\right)$ et accessoirement zirconolite, baddeleyite et srilankite dans les marbres dolomitiques; diopside, phlogopite, scapolite, sphène et accessoirement zircon et graphite dans les marbres calciques. Ceci définit un pic métamorphique de haute température, basse pression proche de $700-750{ }^{\circ} \mathrm{C}, \leq 4.5 \mathrm{kbar}$. Dans le chevauchement FBBSZ, des structures de second ordre sont des zones de cisaillement ductiles à vergence NW amenant des écailles de kinzigites sur les marbres. À l'intérieur de ces derniers, les plis mineurs d'axe NNE sont dominants. Ces structures mylonitiques sont recoupées par des failles normales tardives à pendage nord. Les analyses SHRIMP U-Th-Pb dans le cœur des grains de zircon extraits des marbres indiquent des pics d'âge à $\sim 270 \mathrm{Ma}$ et $\sim 340 \mathrm{Ma}$, tandis que les bordures fournissent des âges Miocène inférieur ( 21 Ma). Les corrélations avec les contextes comparables dans les autres chaînes alpines de Méditerranée occidentale sont examinées. Nous proposons de corréler les marbres des Beni Bousera avec les séries triasiques déposées sur les unités crustales des Alpujarrides-Sebtides. Les protolithes des marbres se sont déposés en transgression sur les kinzigites ou bien y ont été amenés comme allochtones extensionnels durant le Lias au-dessus d'un détachement liéà la formation de la marge continentale du Domaine d'Alboran. Ainsi, les roches mantelliques auraient été exhumées à faible profondeur dès le Trias durant la formation initiale d'une marge hyper-étirée au bord septentrional de la Téthys maghrébine.
\end{abstract}

Mots clés : Arc de Gibraltar / exhumation du manteau / Téthys alpine / métamorphisme de haute température / rifting triasique / marges hyper-étirées / datation U-Th-Pb SHRIMP

'What is now proved was once only imagined' William Blake

\section{Introduction}

At the westernmost tip of the West Mediterranean Alpine belts, the Gibraltar Arc is famous for its large massifs of subcontinental peridotites, up to $\sim 5 \mathrm{~km}$ thick, i.e., the Ronda massifs in the northern (Spanish) branch of the arc, and the Beni Bousera massif in the southern (Moroccan) branch (Fig. 1), both topped by a granulitic cap a few hundred meters thick. These massifs are included in a complex of crustal nappes, i.e., the Alpujarrides (Spain)-Sebtides (Morocco) Complex, which, together with the underlying NevadoFilabrides of Spain and the overlying Malaguides (Spain)Ghomarides (Morocco) nappes, constitutes the Alboran Domain (see reviews in Chalouan et al., 2008; Jabaloy Sánchez et al., 2019a, 2019b). The exhumation history of the Gibraltar Arc peridotites has been hotly debated since the 1970s. Contrary to the hypothesis of a Neogene "hot diapiric emplacement" of Loomis (1972), Kornprobst (1974) ascribed the mantle uplift to Variscan compressional tectonics, whereas Reuber et al. (1982) and Saddiqi et al. (1988) favored an early uplift in the framework of the Mesozoic crustal extension of the Mediterranean domain. In a pioneering paper, Kornprobst and Vielzeuf (1984) compared the Ronda-Beni Bousera lherzolites with those of the Pyrenees (Fig. 2A) and emphasized the major role of extension. Michard et al. (1991, 1997) compared the Ronda-Beni Bousera peridotites with those of Ivrea in the Western Alps, whose earliest exhumation is related to Permian-Jurassic extensional tectonics (Brodie et al., 1989; Vavra et al., 1999).

A decisive step was achieved when Sánchez-Rodríguez and Gebauer (2000) obtained Jurassic-Early Cretaceous U-Pb zircon ages from garnet pyroxenites in the Ronda peridotites, and concluded that these ages were linked to the breakup of Pangea. These authors also obtained $\sim 20 \mathrm{Ma}$ ages from zircon rims from the underlying crustal nappe and ascribed these overgrowths to a Miocene subduction event. Li and Massonne (2018) recently assigned a $\sim 40 \mathrm{Ma}$ age to the subduction event recorded in the Nevado-Filabrides. This event is part of the slab rollback model (Fig. 2B) developed to account for the Late Eocene-Pliocene opening of the West Mediterranean basins and coeval building of the surrounding Alpine belts (Royden, 1993; Lonergan and White, 1997; Frizon de Lamotte et al., 2000; Spakman and Wortel, 2004; Jolivet et al., 2009; Van Hinsbergen et al., 2014). In this model, the Alboran Domain is part of an Alboran-Kabylias-Peloritani-Calabria block (AlKa$\mathrm{PeCa}$, also spelt Alkapeca; Bouillin et al., 1986; Dercourt et al., 1986) drifted by back-arc spreading from the southeastern margin of Iberia from $\sim 35 \mathrm{Ma}$ onward (Fig. 2C, left). However, the timing and mechanism of exhumation of the Gibraltar Arc peridotites remained debated. Michard et al. (2002) and Chalouan and Michard (2004) defended the hypothesis of an early exhumation during the 

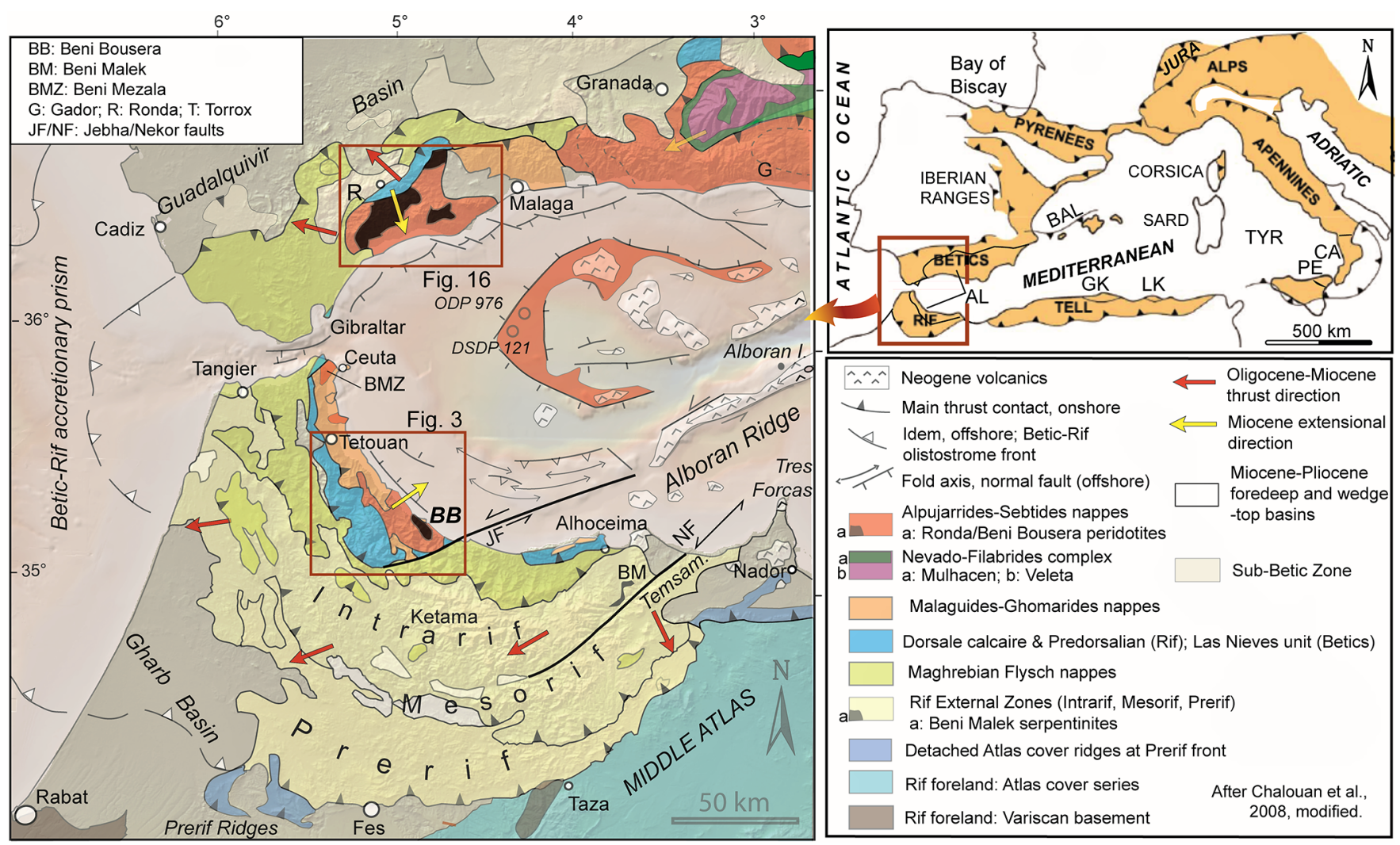

Fig. 1. Structural map of the Gibraltar Arc, modified after Chalouan et al. (2008). Insert: location (framed) in the Western Mediterranean area (Alpine belts in ochre). AL: Alboran; BAL: Balearic Islands; CA: Calabria; GK/LK: Greater/Lesser Kabylias; PE: Peloritani Mts; SARD: Sardinia; TYR: Tyrrhenian Sea.

Jurassic opening of the Alpine Tethys. In contrast, Platt et al. (2003) proposed rapid exhumation of the mantle rocks by delamination of the lithospheric mantle between $\sim 25 \mathrm{Ma}$ and $20 \mathrm{Ma}$

Currently, the role of Permian-Mesozoic extension is accepted, but is generally regarded as minor compared to Oligocene-Miocene tectonic events. Garrido et al. (2011) related exhumation from depths of $\sim 140$ to $\sim 85 \mathrm{~km}$ to the Tethyan extension. The deeper value was linked to the occurrence of diamond pseudomorphs and microdiamonds in pyroxenites (Davies et al., 1993; El Atrassi et al., 2011), whereas the shallower value corresponds to the observation of graphite-garnet facies in the lherzolites. However, Garrido et al. (2011) ascribe the exhumation of the mantle rocks up to $30-40 \mathrm{~km}$ depth to an Oligocene-Early Miocene extension in a back-arc setting linked to the westward subduction of the Tethyan lithosphere (Fig. 2D). Most authors currently adopt similar views to describe a long-term exhumation of the Ronda-Beni Bousera peridotites (Afiri et al., 2011; Précigout et al., 2013; Álvarez-Valero et al., 2014; Hidas et al., 2015; Gueydan et al., 2015; Gervilla et al., 2019). However, Rossetti et al. $(2010,2020)$ and Melchiorre et al. (2017) demonstrated that the Beni Bousera peridotites were exhumed to lower-crust depth during the waning stage of the Hercynian orogeny. The final exhumation of the peridotite massifs is attributed to the Alpine orogeny, but is variably depicted in the recent literature (e.g., Mazzoli and Martín Algarra, 2011; Tubía et al., 2012; Gueydan et al., 2019; Rossetti et al., 2020).
In this study, we report new field and laboratory data involving detail mapping, structural analysis, petrological studies, and SHRIMP (Sensitive High-Resolution Ion Microprobe) dating of zircon grains from marble outcrops scattered around the Beni Bousera massif. Kornprobst (1974) considered these marbles as mere intercalations within the metapelitic series of the kinzigites (granulites) topping the peridotites. This interpretation was subsequently accepted by all geologists working in the area, including the present authors (Reuber et al., 1982; Saddiqi, 1988; Chalouan and Michard, 1990), at least until last year, when we observed that the marbles are exclusively located on top of the kinzigite envelope and below the gneisses of the Filali Unit (Saddiqi et al., 2019; Michard et al., 2020a). The new data presented here support the early extensional exhumation of the Beni Bousera peridotites to close to the surface during the TriassicEarly Jurassic rifting of Pangea. In light of these results and correlations with similar settings from the Betics to the Central Alps, we propose that this early exhumation occurred in the framework of the incipient formation of the southwestern Alkapeca continental margin, north of the Maghrebian Tethys.

\section{Geological setting}

In the Rif Chain, the Alboran Domain tectonic wedge forms a backstop to an external tectonic wedge thrust over the North African crust (Figs. 1 and 3). The external wedge mostly 


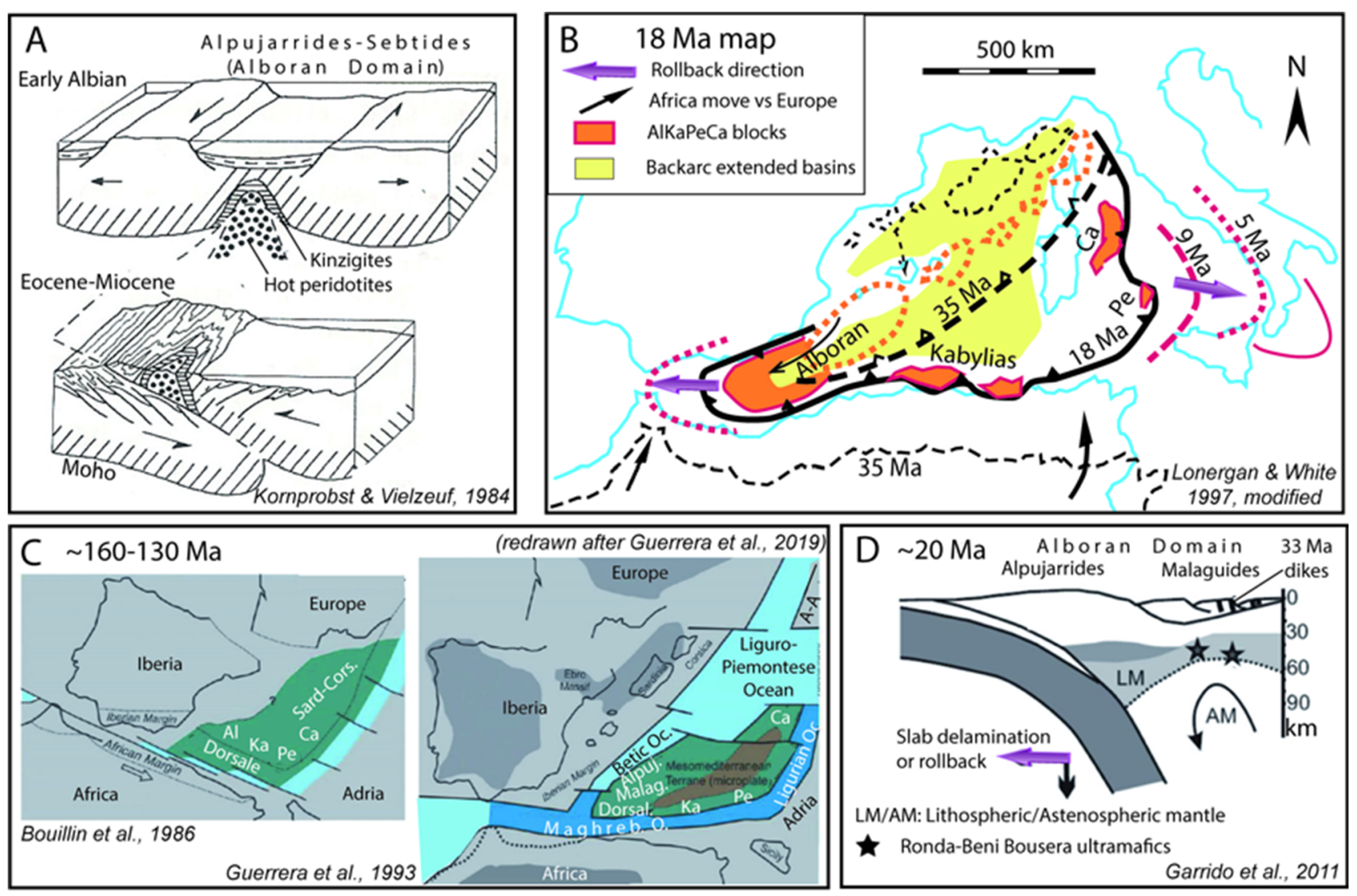

Fig. 2. A: Early extensional exhumation of the Ronda-Beni Bousera peridotites, according to Kornprobst and Vielzeuf (1984). B: Rollback model accounting for building of the West Mediterranean Alpine belts and opening of the Western Mediterranean, modifed after Lonergan and White (1997). Ca: Calabria; Pe: Peloritani Mts. C: Contrasting restorations of the Tethyan realm between Africa, Adria, Iberia and Western Europe, according to Bouillin et al. (1986) and Guerrera et al. (1993), respectively (after Guerrera et al., 2019). The "Betic Ocean" is named after Puga (1990). D: Lithospheric scale cross-section showing the Neogene exhumation of the Ronda-Beni Bousera peridotites at $40 \mathrm{~km}$ depth in the framework of N- to NE-dipping subduction and correlative back-arc extension, preceding the final compressional deformation of the RifBetic orogen, after Garrido et al. (2011).

consists of sedimentary units involving two types of nappes, from top to bottom: (i) the Maghrebian Flyschs nappes, i.e., the Upper Jurassic-Early Miocene infilling of the LigurianMaghrebian Tethys, also extending to the Western Betics (Bouillin et al., 1986; Leprêtre et al., 2018; Daudet et al., 2020), and (ii) the Intrarif, Mesorif and Prerif parautochthonous and allochthonous units formed during OligoceneMiocene inversion of the North African hyperextended margin and comprising obducted units of the adjacent Tethyan crust (Favre, 1992; Michard et al., 2007, 2014, 2020b; Benzaggagh et al., 2014; Gimeno-Vives et al., 2019).

The stacked nappes of the Alboran Domain are thrust over the Flyschs and External zones of North Africa and Iberia (Fig. 1). However, late extensional faulting strongly affected this internal tectonic wedge whose Early Miocene collapse accompanied the opening of the Alboran basin (GalindoZaldivar et al., 2019; Lafosse et al., 2019). In the Rif belt, the lowest unit of the internal wedge (lower Sebtides) crops out at Ceuta (Fig. 1) and comprises the Monte Hacho orthogneiss underlying a $\sim 200 \mathrm{~m}$ thick serpentinite-granulite unit (Homonnay et al., 2018). The lower Sebtides are correlated with the Alpujarride nappe (Ojen-Guadaiza nappe) widely exposed beneath the Ronda peridotites in the Western Betics (Jabaloy Sánchez et al., 2019a, 2019b). In the Central Betics, the Alpujarrides nappe complex overlies the NevadoFilabrides Complex (Fig. 1). In this entirely eclogitic complex (Santamaria-Lopez et al., 2019), the lowest unit is regarded as proximal with respect to the Iberian plate (e.g., Augier et al., 2005; Rodríguez-Cañero et al., 2018; Pedrera et al., 2020) whereas the overlying meta-ophiolites are considered to record a lost oceanic branch of the western Tethys, i.e., the Betic Ocean (Puga, 1990; Puga et al., 2005; Fig. 2) or West Ligurian Ocean (Leprêtre et al., 2018).

The Lower Sebtides are widely exposed in the Beni Bousera antiform (Fig. 3A). There, the base of the peridotites is not exposed, but their thickness exceeds $2500 \mathrm{~m}$ (Fig. 3B). They mainly consist of spinel lherzolites, including 5-10\% of ultra high-pressure (UHP) pyroxenites (Gysi et al., 2011; Frets et al., 2014; Chetouani et al., 2016; Varas-Reus et al., 2018). They are overlain by a $200-500 \mathrm{~m}$ thick granulitic envelope traditionally labeled kinzigites and grouped with the ultramafics in the high-pressure (HP) "Beni Bousera Unit" (Kornprobst, 1974). The kinzigites mainly consist of migmatitic metapelites characterized by the assemblage 


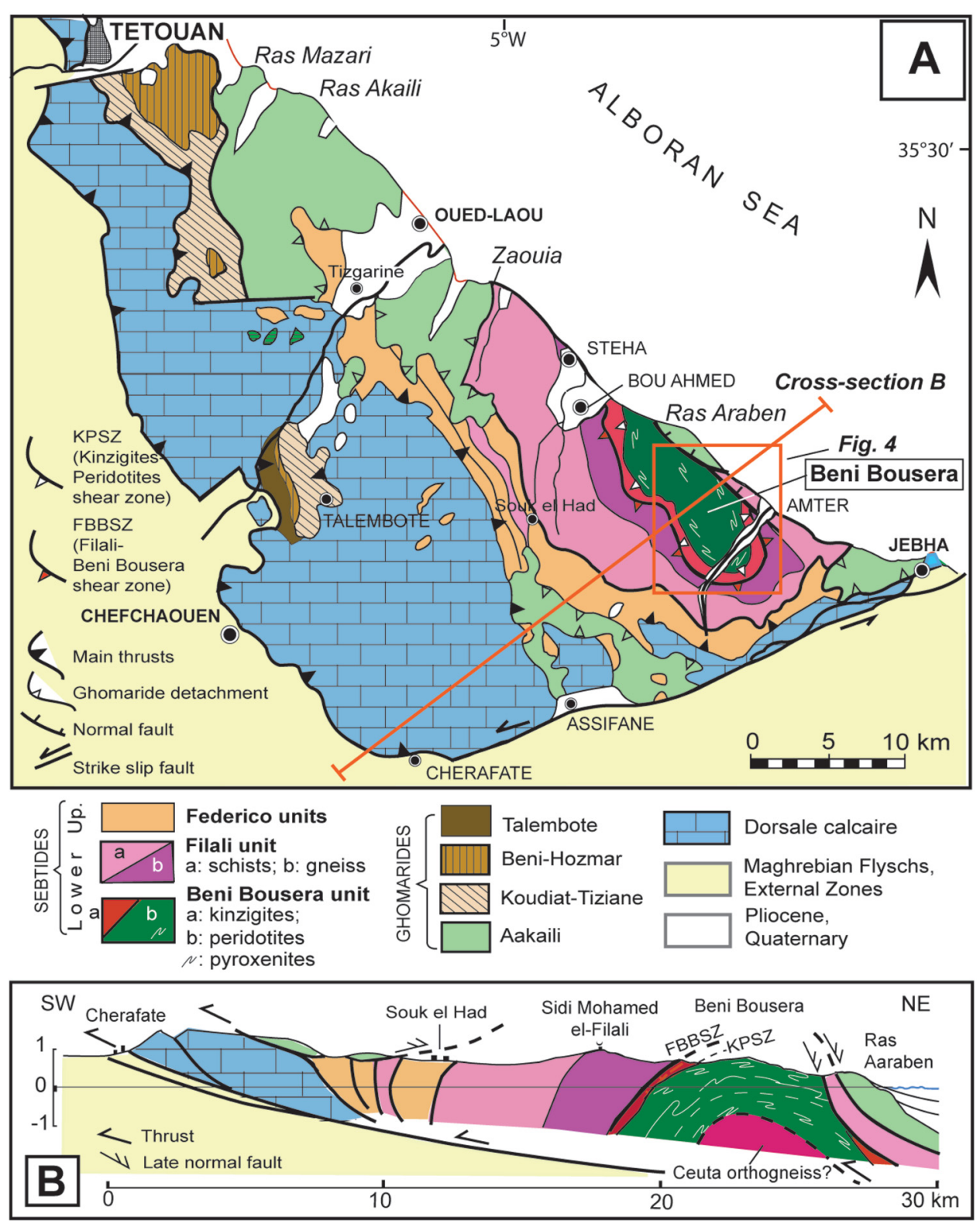

Fig. 3. Structural map (A) and cross-section (B) of the Northern Rif Internal zones (Alboran Domain) from Tetouan to Jebha, modified after Suter (1980) and Chalouan et al. (2008). The shear zones on both sides of the kinzigites granulitic unit are distinguished here for the first time and labeled KPSZ and FBBSZ, respectively (see A for explanation of acronyms).

garnet-kyanite-rutile \pm biotite-sillimanite and include metabasite lenses (Bouybaouene et al., 1998; Haissen et al., 2004; Álvarez-Valero et al., 2014). They are currently regarded as lower-crustal rocks separated from the ultramafics by a major extensional shear zone (Saddiqi et al., 1988; Afiri et al., 2011; Gueydan et al., 2015, 2019) hereafter labeled the "KinzigitePeridotite Shear Zone" (KPSZ, Figs. 3-5). Immediately beneath the kinzigites, the porphyroclastic spinel peridotites are replaced by garnet-spinel mylonites that include corundum-garnet or plagioclase-garnet pyroxenites interpreted as derived from subducted slices of the crust-mantle boundary (Chetouani et al., 2016) and subsequently exhumed by $24 \pm 3 \mathrm{Ma}$ (Lu-Hf; Pearson and Nowell, 2004). Rossetti et al. (2020) dated at 300-290 Ma (U-Pb zircon) the migmatitic granulite; they assume that the mantle and lower-crust rocks were coupled twice, firstly at great depth $(\sim 50 \mathrm{~km})$ during the waning stage of the Hercynian orogeny, and secondly in the cordierite stability field $(<15 \mathrm{~km})$ during the last stage of the Alpine orogeny (zircon rims at 20-21 Ma).

The Beni Bousera Unit is draped by the $\sim 5 \mathrm{~km}$-thick Filali Unit, which includes two sub-units, i.e., the Filali Gneiss and overlying Filali Schists (Figs. 3A, B and 4). Both sub-units exhibit mineral associations typical of high-temperature, lowpressure (HT-LP) conditions, from sillimanite-K-feldspar in the gneiss, to kyanite-, to andalusite \pm staurolite assemblages in the schists (El Maz and Guiraud, 2001). Evidence of partial melting occurs in the lower sub-unit in the form of kyanitegarnet leucocratic granitic lenses (leptynites of Kornprobst, 1974). Like the kinzigites, the Filali Unit records a polyphase evolution, i.e., Barrovian metamorphism during the Hercynian 


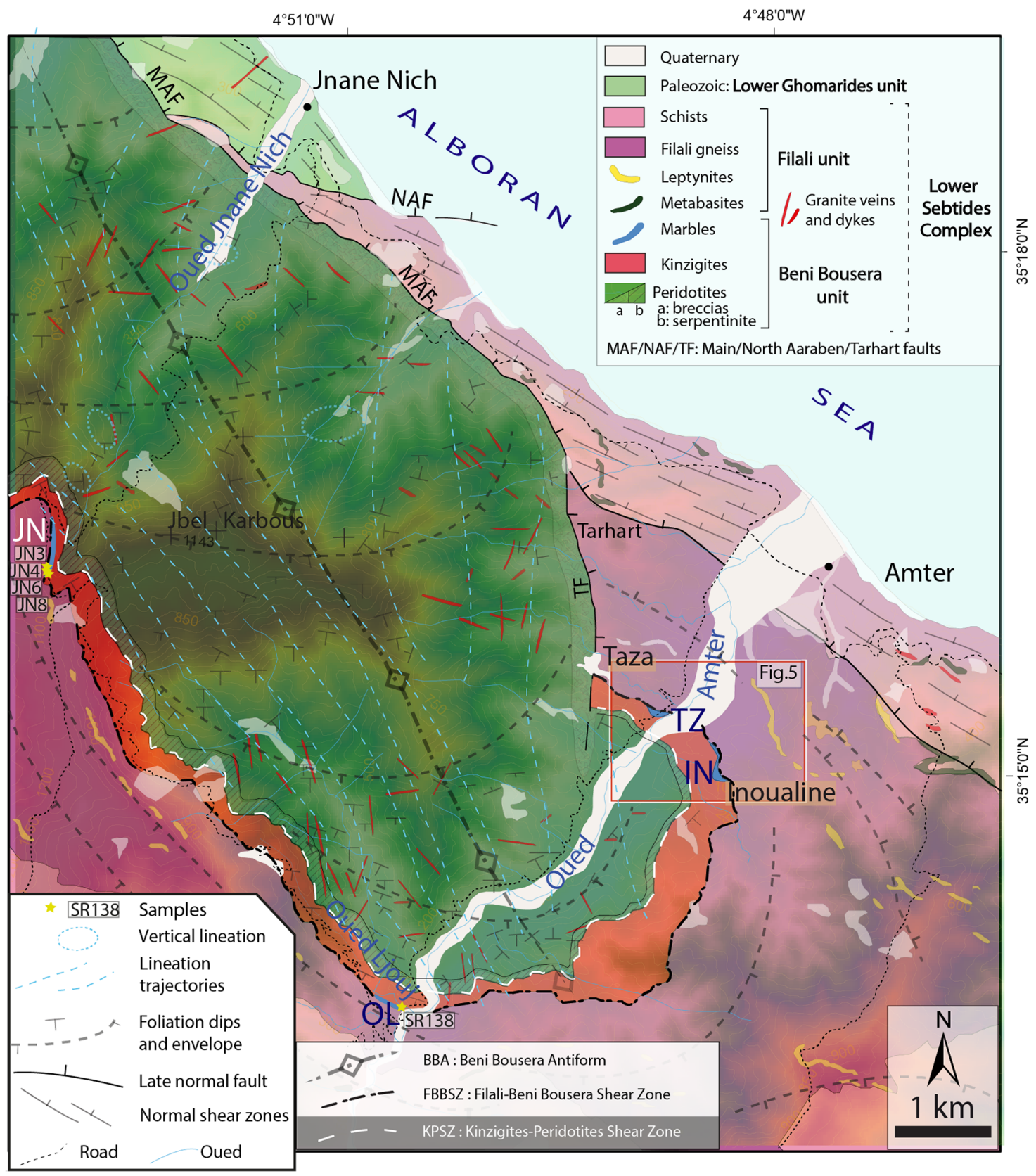

Fig. 4. Geologic map of the southeastern part of the Beni Bousera massif, after the Geological Map of Morocco, scale 1:50,000, sheets Bou Ahmed and Bab Berred (mapping by J. Kornprobst), with additions from Reuber et al. (1982), Elbaghdadi et al. (1996), Afiri et al. (2011), Frets et al. (2014), El Bakili et al. (2020) and this work (marbles). The TZ (Taza), IN (Inoualine), OL (Oued Ljouj) and JN (Jnane Niche) marble outcrops underline the Filali-Beni Bousera Shear Zone (FBBSZ).

orogeny (late anatectic phase at $\sim 300 \mathrm{Ma}$; U-Pb zircon dating of the leptynites) and HT-LP during the Alpine orogeny ( $22 \mathrm{Ma}$; U- $\mathrm{Pb}$ zircon/monazite and ${ }^{40} \mathrm{Ar} /{ }^{39} \mathrm{Ar}$ muscovite/ biotite) (Rossetti et al., 2010; see also Gueydan et al., 2015). The Filali Unit corresponds to a thinned upper-crust section, currently regarded as separated from the underlying Beni Bousera Unit by an extensional shear zone parallel to the KPSZ (Saddiqi et al., 1988; Chalouan et al., 2008; Afiri et al., 2011; Álvarez-Valero et al., 2014; Gueydan et al., 2015, 2019). The occurrence of the marbles (BBMs) studied here between the Beni Bousera and Filali Units questions this classical interpretation, as soon as the age of their protoliths may be post-Paleozoic. We have distinguished this limit under the name of Filali-Beni Bousera Shear Zone (FBBSZ), as explained below (Sect. 4.1).

The uppermost section of the Sebtides complex is defined by the Federico units, which are characterized by a distinct MP-HP/LT metamorphic signature and overlie the Lower Sebtides through a tectonic contact (Fig. 3A, B). Three units are distinguished in the Beni Bousera region, according to their metamorphic grade, which decreases from bottom to top, i.e., from the Souk-el-Had (late cordierite-andalusite assemb- 
lages), to Boquete (sudoite-chloritoid), to Tizgarine (cookeite-pyrophyllite) units (Bouybaouene, 1993). In contrast, their sandy-pelitic lithology is homogeneous and derives from Permian-Early Triassic red beds and quartzites series (Kornprobst, 1974). The Souk-el-Had unit is regarded as the detached stratigraphic cover of the Filali basement (Bouybaouene, 1993). Middle to Upper Triassic dolomites are associated with the Federico units in the Beni Mezala Sebtides antiform west of Ceuta (BMZ, Fig. 1; Durand-Delga and Kornprobst, 1963). The two lower Beni Mezala units display mineral associations typical of blueschist to eclogite metamorphic facies (Bouybaouene et al., 1995; Michard et al., 1997, 2006; Vidal et al., 1999; Janots et al., 2006; Marrone et al., 2020). Ladinian to Norian beds have been identified in their Betic equivalents of the western Alpujarrides, namely the Casares-Benarraba imbrications (Balanyá et al., 1997; Sanz de Galdeano et al., 1999).

The Ghomarides complex comprises four nappes that overlie the Sebtides complex through extensional contacts of two types (Fig. 3B), either low-angle normal faults on top of the tectonic pile (e.g., Zaouia fault) or steep normal faults dipping toward the Alboran basin (Aaraben faults). Each Ghomarides nappe involves a low-grade Paleozoic basement and at least part of its post-Variscan unconformable cover (Chalouan and Michard, 1990). In the two lowest nappes, remnants of the sedimentary cover consist of Anisian-Carnian red beds (Baudelot et al., 1984), which can be correlated with the Verrucano of Tuscany (Perrone et al., 2006). To the north of Tetouan, the Beni Hozmar nappe is overlain by a locally preserved thin $(\sim 50 \mathrm{~m})$ sequence of Liassic carbonates and Lower Eocene sandy limestones (El Kadiri et al., 1992), which are covered by an Oligocene-Miocene, syntectonic marlyclastic cover (El Kadiri et al., 2001). The lower Ghomarides pile underwent metamorphic recrystallization at temperatures up to $500{ }^{\circ} \mathrm{C}$ (Negro et al., 2006) at about $25 \mathrm{Ma}$ (Michard et al., 1991).

The "Dorsale calcaire" complex extends across the front and below the Alboran Domain internal wedge (Fig. 3B), except to the north of Tetouan where the wedge is pinched and tilted backward (eastward). The Dorsale complex includes several small units characterized by a slab of Upper TriassicLiassic carbonates overlain by relatively thin JurassicCretaceous pelagic facies, and unconformable Eocene-Early Miocene formations (El Kadiri et al., 1992, 2000-2002a; Chalouan et al., 2008). Based on their stratigraphy these strata were classified into "Internal" and "External" Dorsale units: the Internal Dorsale comprises Triassic stromatolithic limestones overlain by white Liassic limestones, whereas the External Dorsale is typified by alternating beds of Triassic limestones and dolostones followed by dark, cherty Liassic limestones and Middle-Upper Jurassic radiolarites. From the Betics to Sicily, these units are currently viewed as having been derived from the Mesozoic passive margin separating the Malaguide-Ghomaride-Kabylian high from the Maghrebian Flyschs basin (Bouillin, 1986; Cattaneo et al., 1999; DurandDelga, 2006; Martín-Martín et al., 2006; El Kadiri et al., 2009). The "Pre-Dorsalian" units (e.g., Cherafat slivers southwest of Beni Bousera, and the "Hercules columns" on both sides of the Strait of Gibraltar) were located in the most distal part of this margin (Olivier, 1990; Durand-Delga et al., 2007), transitional to the Flyschs basin substrate (Olivier et al.,
1996). They are now disrupted and sheared in the sole of the Alboran Domain tectonic wedge.

\section{Samples and methods}

We first resumed the study of the marbles in the Oued Amter valley (Fig. 4) where we had previously described marble outcrops (Saddiqi, 1988). The marbles were now mapped south of Taza village, north of Inoualine, and at the Oued Ljouj-Oued Amter confluence (Fig. 5). As the marble outcrops appeared to be linked to the upper boundary of the Beni Bousera kinzigites in the mapped area, we searched for other marbles along the southwestern flank of the Beni Bousera Unit from the Oued Ljouj to the crest of the massif, where we discovered a large marble outcrop in the predicted location (JN, Fig. 4). Structural data were collected at many stations, on both flanks of the Beni Bousera antiform. In order to visualize these data, we use the Stereonet software by Richard Allmendinger (C) 2011-2020 version 11.1.3 with a lowerhemisphere equal-area projection (Allmendinger et al., 2013; Cardozo and Allmendinger, 2013).

Thirty-three samples were collected within and around the marble outcrops (Tab. 1), with locations shown in Figures 4 and 5. Petrological/textural analyses were performed at École normale supérieure, Paris, using polarizing microscopy and a ZeissSigma field-emission-gun scanning electron microscope equipped with a large-area $\left(50 \mathrm{~mm}^{2}\right)$ energy-dispersive silicon drift detector, X-Max Oxford Instruments, for standardless analysis in carbon-coated polished thin sections using the Aztec software, Oxford Instruments. Micrometer-size calcite inclusions in forsterite were analysed for calcite-dolomite thermometry (Ferry, 2001, using the formulation of Anovitz and Essene, 1967); operating conditions were accelerating voltage $15 \mathrm{kV}$ and beam current $9 \mathrm{nA}$, Si content was monitored to avoid a possible contribution from the host olivine and counting time was reduced to $2 \mathrm{~s}$ in order to limit beam damage to the carbonate. To back the petrological discussion, we used phase relations calculated in the $\mathrm{CaO}$ $\mathrm{MgO}-\mathrm{Al}_{2} \mathrm{O}_{3}-\mathrm{SiO}_{2}-\mathrm{H}_{2} \mathrm{O}-\mathrm{CO}_{2}$ system for the composition 1 clinochlore +5 calcite +10 dolomite with the Theriak/Domino software (de Capitani and Petrakakis, 2010; version 03.01.2012) and the JUN92d2019 updated database of Berman (1988).

Five samples were collected $(1-3 \mathrm{~kg})$ from marble outcrops on both sides of Oued Amter (Fig. 5, samples MTS5, MTS6, MTS14-15, MTS17, MTS18) to extract zircon grains for SHRIMP analysis. Samples were broken into smaller pieces, cut using a diamond saw, then fragmented with a jaw-crusher in the Geosciences Laboratory, Faculty of Sciences Aïn Chock, Hassan II University of Casablanca, Morocco. The fragments were sieved to concentrate the size fraction $80-300 \mu \mathrm{m}$. Potential zircon-bearing fractions were separated using panning, first in water and then in ethanol. Only three samples yielded sufficient zircon grains to undertake SHRIMP analysis with a perspective of detrital zircon study: (i) MTS5 from the metaconglomeratic bed near the base of outcrop 1a; (ii) MTS6 from the impure marbles of outcrop 1b; and (iii) MTS18 from a calcschist bed of outcrop 1c (Fig. 5). After extracting the magnetic fraction with a neodymium magnet, zircon grains were handpicked under a 


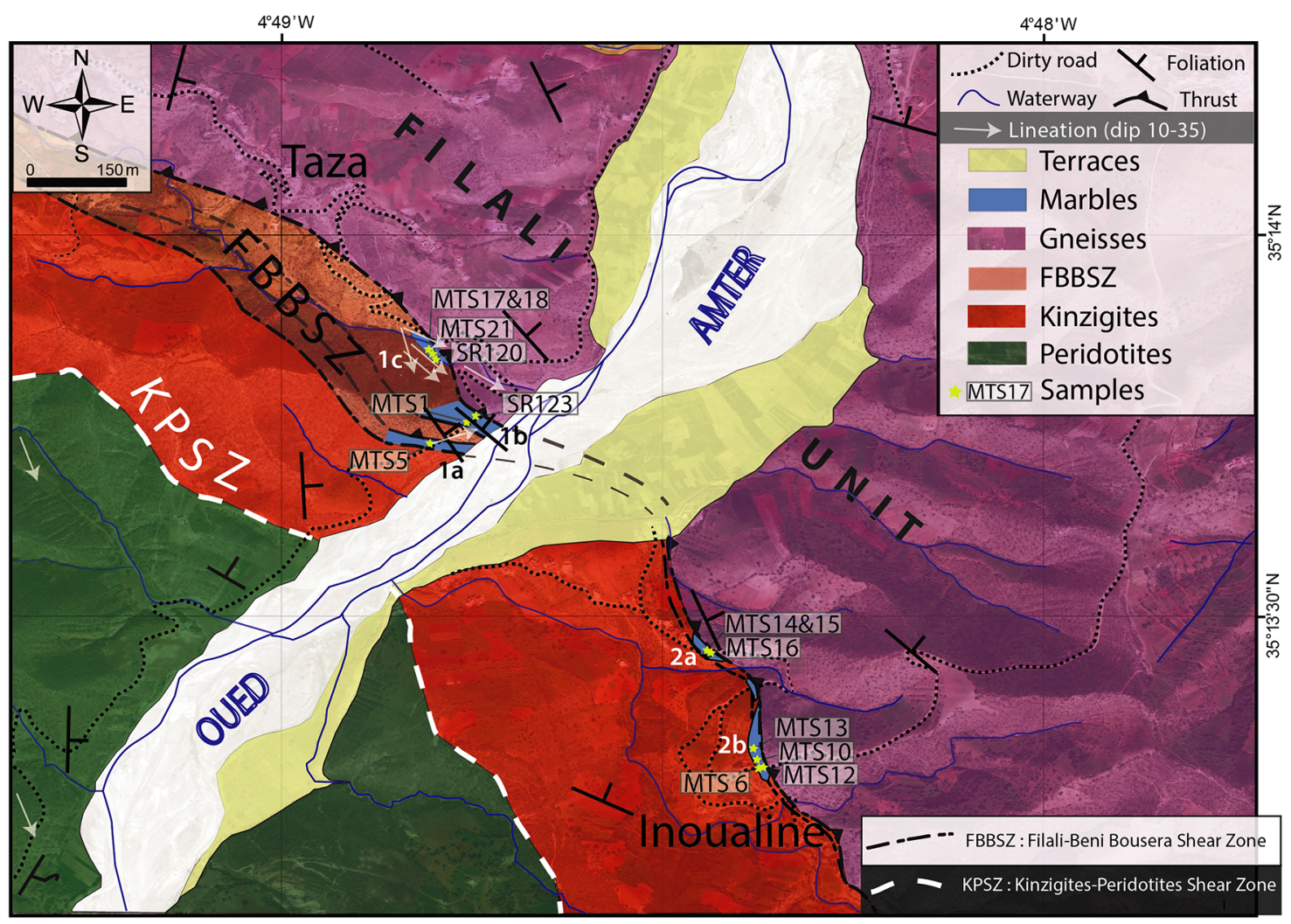

Fig. 5. Map of northwestern marble outcrops, $\sim 7 \mathrm{~km} \mathrm{SW}$ of Amter-village (see Fig. 4 for location), with sample locations. 1a-1c: Amter road outcrops (from SW to NE). 2a-2b: Inoualine outcrops. The Filali-Beni Bousera Shear Zone (FBBSZ) has not been mapped west of 1a-1c.

binocular microscope. About 150 zircon grains for samples MTS5 and MTS6, and 60 for MTS18 were mounted along with standards on a $3.5 \mathrm{~cm}$ diameter epoxy SHRIMP megamount. Zircons were polished, studied by optical (reflected and transmitted light) and scanning electron microscopy (secondary electrons and cathodoluminescence images), coated with a $13-15 \mathrm{~nm}$ thick gold layer, and analyzed for $\mathrm{U}-\mathrm{Th}-\mathrm{Pb}$ using a SHRIMP IIe/mc ion microprobe at the IBERSIMS laboratory of the CIC University of Granada, Spain. The SHRIMP U-Th$\mathrm{Pb}$ analytical method is described in detail at www.ugr.es/ ibersims. Each selected spot was rastered with the primary beam for $120 \mathrm{~s}$ prior to analysis, and then analyzed by 6 scans, following the isotope peak sequence ${ }^{196} \mathrm{Zr}_{2} \mathrm{O},{ }^{204} \mathrm{~Pb}$, 204.1 background, ${ }^{206} \mathrm{~Pb},{ }^{207} \mathrm{~Pb},{ }^{208} \mathrm{~Pb},{ }^{238} \mathrm{U},{ }^{248} \mathrm{ThO}$, and ${ }^{254} \mathrm{UO}$. Each peak of every scan was measured sequentially 10 times with the following total counting times per scan: $2 \mathrm{~s}$ for mass $196 ; 5 \mathrm{~s}$ for masses 238,248 , and $254 ; 15 \mathrm{~s}$ for masses 204, 206, and 208; and 20s for mass 207. Uranium concentration was calibrated using the SL13 reference zircon (U: 238 ppm; Claoué-Long et al., 1995). U/Pb ratios were calibrated using the TEMORA-II reference zircon (417 Ma; Black et al., 2004), which was measured every 4 unknowns. All calibration procedures were performed on the standards included on the same mount. Mass calibration was done on the REG20 zircon (internal laboratory standard: ca. $2.5 \mathrm{Ga}$, very high U, Th, and common lead content). Data reduction was carried out with the SHRIMPTOOLS software (downloadable from www.ugr.es/fbea) using the STATA $^{\mathrm{TM}}$ programming language.

\section{Results}

\subsection{Marble outcrops}

At a regional scale (Fig. 4), the marble outcrops form lensshaped exposures (TZ, IN, OL, JN) exclusively located in between the kinzigite envelope of the Beni Bousera peridotites and the overlying Filali gneisses. As noticed above (Sect. 2; Fig. 3), we have distinguished this limit under the name of Filali-Beni Bousera Shear Zone (FBBSZ). Along this contact, the most significant outcrops are observed on the western bank of Oued Amter, south of Taza village, along the Amter track, and in the narrow Oued Taza valley (Fig. 5, outcrops 1a-1c). Here, the FBBSZ is nearly $150 \mathrm{~m}$ thick, whereas at Inoualine, on the opposite bank of Oued Amter, marble lenses $2 \mathrm{a}, 2 \mathrm{~b}$ (Fig. 5) are pinched within a narrow, $\sim 30 \mathrm{~m}$ thick shear zone. The variation in thickness observed at the different outcrops can be largely attributed to the tectonic deformation that affected the marbles in the FBBSZ (see Sect. 4.2 below). Marble outcrops of the Taza and Inoualine lenses commonly exhibit bedding confirming the sedimentary nature of the protoliths. This is best exemplified by the thinly bedded marbles with interleaved meta-argillites (now biotite-vermiculite schists) outcropping in Oued Taza (Fig. 6B). Likewise, outcrop 1a (Fig. 5) displays conspicuous bedding marked by alternating pure and siliceous/silicate-rich carbonate layers (Fig. 6C). The state of the silica component in the protolith may have been diffuse (chert) and/or detrital sand (see Sect. 5.1), but the occurrence of a metaconglomeratic bed (Fig. 6D) 


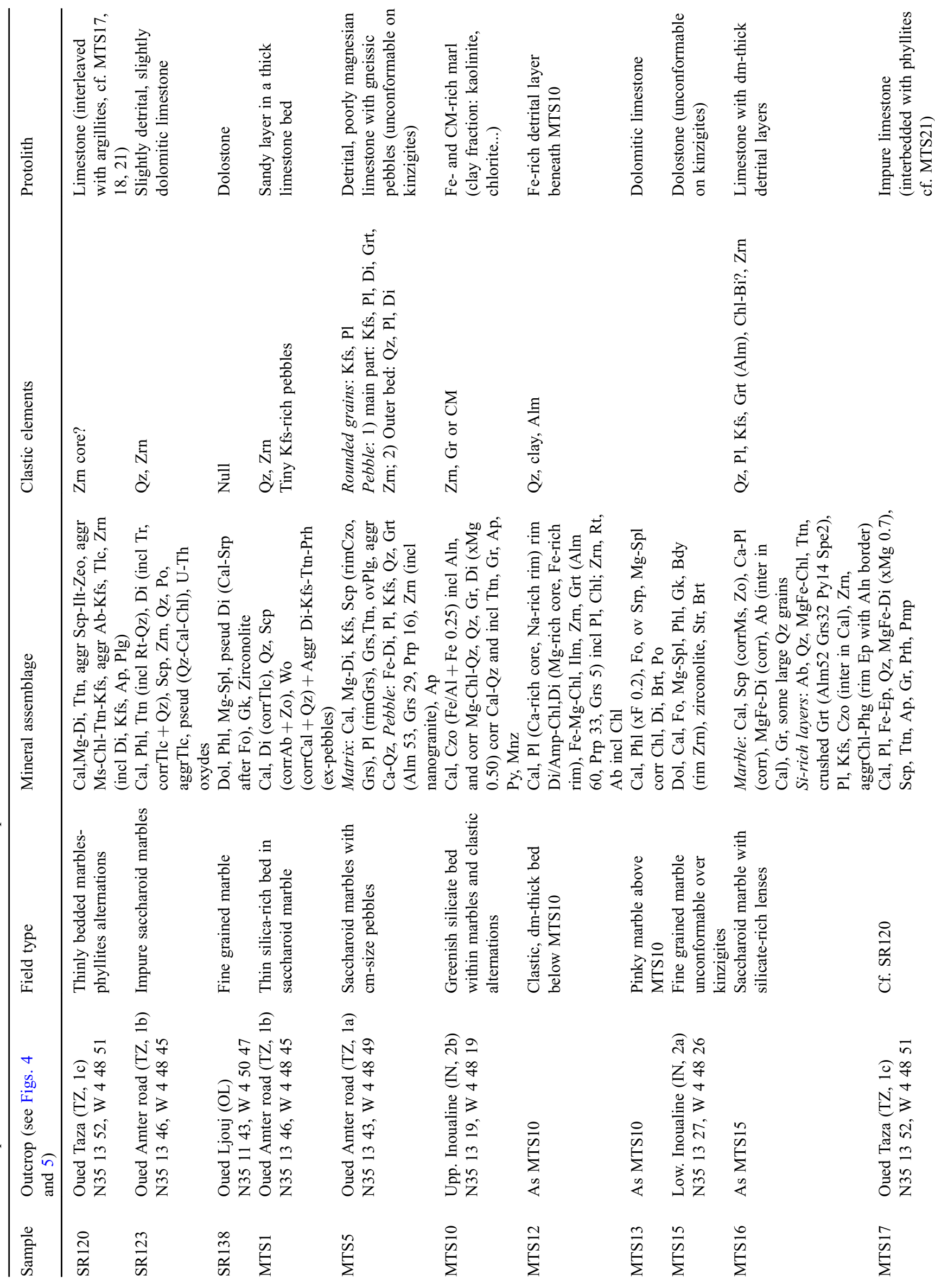


A. Farah et al.: BSGF 2021, 192, 26

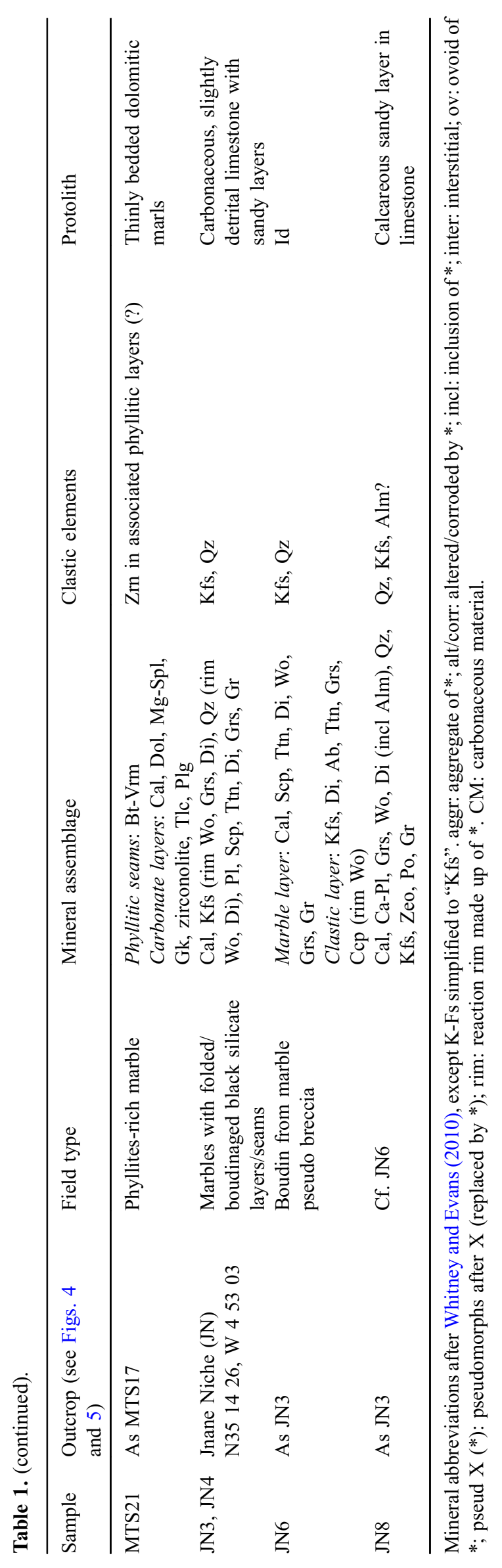

Page 10 of 35 

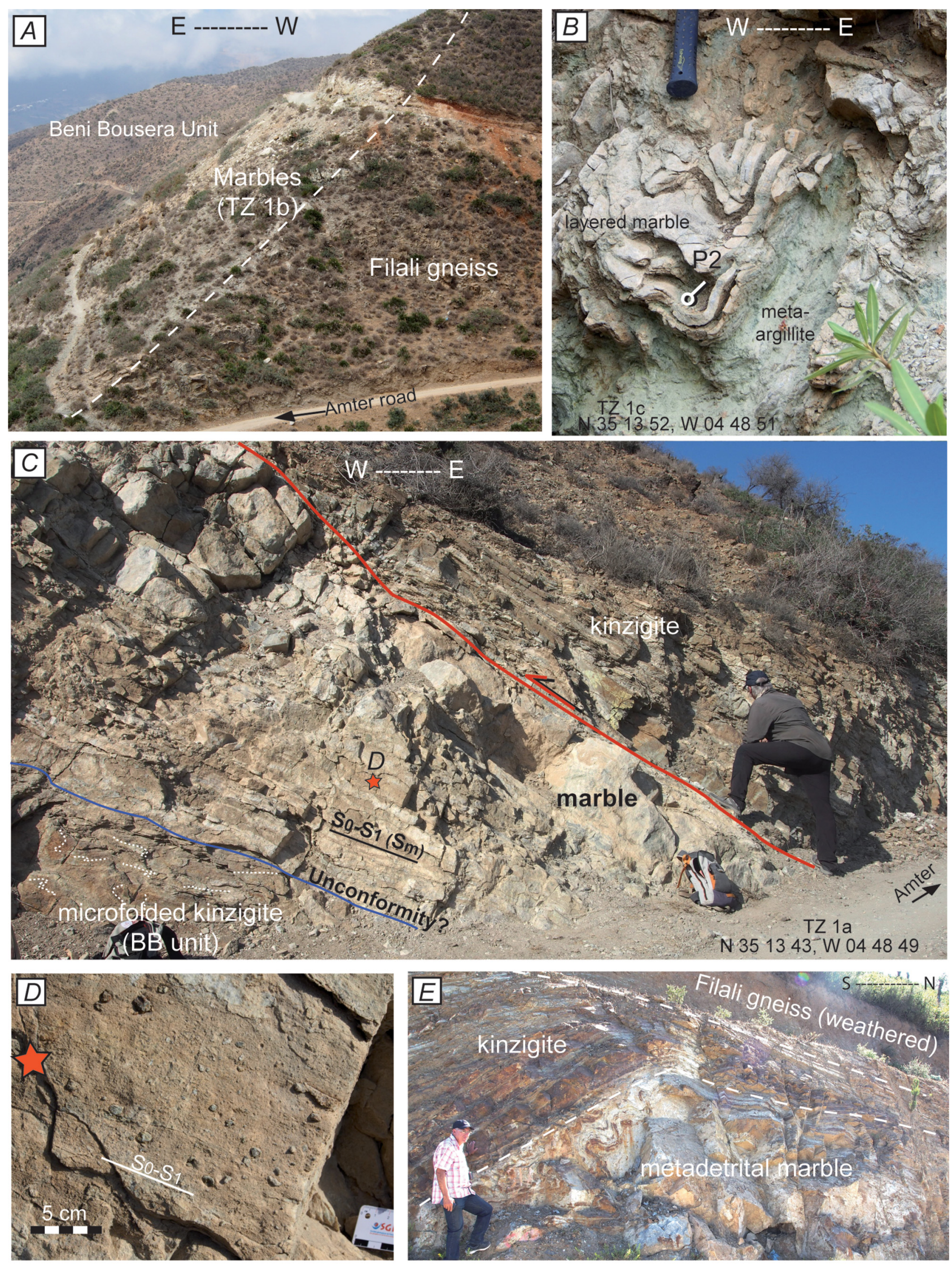
Fig. 6. A: Panoramic view of marble outcrops from the NE side of Oued Taza valley (see location 1b, Fig. 5). The Filali gneiss in the foreground belongs to the hanging-wall of the FBBSZ. B: Close view of the thinly banded marbles cropping out along Oued Taza, at $\sim 200 \mathrm{~m}$ NW of its confluence with Oued Amter (location 1c, Fig. 5). The upright folds (P2) deform the main, bedding-parallel foliation, which is associated with isoclinal folds (P1, see Fig. 7C). C: Outcrop of metadetrital marbles along the Amter road (location 1a, Fig. 5). To the left of the photograph, the kinzigites crop out continuously up to the peridotites, whereas those on the right belong to a second-order sliver included in the FBBSZ. The unconformable contact below the marbles looks like a stratigraphic unconformity, but could alternatively be a low-angle fault. D: Close view of the metaconglomeratic marble bed, $\sim 1 \mathrm{~m}$ above the base of the marbles (red star in C). E: View of the uppermost part of the Oued Jnane Nich marbles (JN, Fig. 4; N 35 14 '26", W $4^{\circ} 53^{\prime} 03^{\prime \prime}$ ). The kinzigite sliver between the marbles and the Filali gneiss is interpreted as part of a horse by comparison with $(\mathrm{C})$.

supports the idea of metadetrital carbonate beds in this sequence. Moreover, the outcrop bedding appears to parallel the basal contact of the marbles over the tightly folded kinzigites of the Beni Bousera Unit (Fig. 6C). However, this contact may be of sedimentary or of tectonic origin as discussed below (Sect. 5).

\subsection{Structures}

Syn- to post-metamorphic structures are observed within the marbles and at their contacts with the surrounding units. Of particular interest is the lower contact of the marble lens 2a (Fig. 5), which within a few square meters shows: (i) a marble bed unconformably overlying the kinzigites of the Beni Bousera Unit, and (ii) two juxtaposed, northwest-ward verging kinzigite-marble duplexes (Fig. 7A). These structures are comparable to those observed in the same position at the basal contact of lens 1a, on the other bank of Oued Amter (Fig. 6C) or at the outcrop $1 \mathrm{~b}$ (Fig. 8C, D). In contrast, the upper limit of lens 1c (Fig. 5) shows conspicuous development of mylonitic structures along with progressive ductile deformation. There, the boudinage of gneissic mylonites (Fig. S1 in Supplementary Material $[\mathrm{SM}]$ ) in the juxtaposed calc-mylonite (Fig. 7B) and the ductile, asymmetric folding of previously boudinaged silica-rich beds (Fig. 7D) are observed. Two types of folds are illustrated within the same marble lens 1c: (i) isoclinal recumbent folds $\left(\mathrm{P}_{1}\right)$ whose axial-planes coincide with the main foliation $\mathrm{Sm}=\mathrm{S}_{0}-\mathrm{S}_{1}$ (Fig. 7C), and (ii) open, upright folds $\left(\mathrm{P}_{2}\right)$ that deform Sm (Fig. 6B). In more massive marbles, syn- $\mathrm{D}_{2}$ crenulation cleavage and brittle-ductile microfaults contribute to flattening of the main foliation, which again parallels bedding $\mathrm{S}_{0}$ (Fig. 7E). Both the ductile and brittleductile structures are overprinted by place by late, easttrending brittle faults with gouge (Fig. 7F) or breccia and striated mirror (Fig. 8E).

The JN outcrop at the source of Oued Jnane Nich (Fig. 4 for location) displays a complex structure involving both kinzigitic and calc-mylonitic sheets (Fig. 7G). These alternating sheets feature sheath/isoclinal folds the core of which is filled by a calc-mylonitic meta-breccia that contains small shreds and fragments of kinzigite-like material (Fig. $7 \mathrm{H}$ ).

In the Oued Ljouj outcrop (OL, Fig. 4), the marbles are reduced to shreds in the shear zone beneath the Filali gneisses. Some lens-shaped blocks of siliceous marbles can be seen in a sheared kinzigite matrix (Fig. 8A, B).

To summarize, the marbles and the intercalated kinzigite bodies (duplexes or slivers) that delineate a decametric corridor at the base of the Filali gneisses are all marked by a strong ductile deformation, which justifies the name we proposed above for this major contact, i.e., Filali-Beni Bousera Shear Zone (FBBSZ). In the kinzigite slivers, the ductile deformation is characterized by recrystallised quartz ribbons, elongate garnet and feldspar porphyroclasts with typical coreand-mantle structure due to dynamic recrystallization (Fig. S1 in SM).

Stretching lineation is $\mathrm{W}$ - to NW-directed with a low to moderate plunge towards $\mathrm{E}$ to SE (Figs. 5 and 9B). In the $\mathrm{FBBZ}$, kinematic criteria such as asymmetrical folding or $\mathrm{C} / \mathrm{S}$ structures are indicative of thrusting toward the west (Figs. 7A, $\mathrm{B}, \mathrm{D}$ and 8).

The data plot collected from different stations shows that the main foliation and marble bedding (Taza marbles) trend NW-SE with an opposite dip consistent with the Beni Bousera anticline (Fig. 9A). Three sets of folds are observed at the regional scale, NW-SE, NE-SW, and E-W (Fig. 9C), reflecting late polyphase FBBSZ activity.

\subsection{Petrology}

The marbles frequently display alternating beds of pure and silicate-rich facies (Figs. 6 and 7), which demonstrates unequivocally their sedimentary origin (Kornprobst, 1974). The critical problem to tackle within the marble samples is to distinguish clastic from metamorphic minerals. A sketchy description of samples is given in Table 1 and we address below four main rock types: conglomeratic marble, standard calcite marble, dolomite marble and siliceous marble.

Of particular interest is the layer marked with a red star in Figure 6C. A clastic input is undisputable for this bed as the $30 \mathrm{~cm}$ thick layer contains pebbles of $0.5-4 \mathrm{~cm}$ in diameter (Fig. 6D). In sample MTS5 from this layer, the pebble studied (Figs. 10 and 11A) comprises a minor quartz-rich part with plagioclase $\left(\sim \mathrm{An}_{60}\right)$ and diopside $(\mathrm{XMg}=\mathrm{Mg} /(\mathrm{Mg}+\mathrm{Fe}) \sim$ 0.7 ) and a main part bearing a complex assemblage of $\mathrm{K}$-feldspar, sodic plagioclase, diopside $(\mathrm{XMg}=\sim 0.7$ to 0.4$)$, quartz, titanite, garnet (ca. $\mathrm{Alm}_{53} \mathrm{Grs}_{29} \operatorname{Prp}_{16} \mathrm{Spe}_{2}$ ), zircon (with small rounded quartz + plagioclase $+\mathrm{K}$-feldspar inclusions), apatite, allanite and late prehnite and pumpellyite. The matrix around the pebble is a recrystallized calcite groundmass containing rounded clasts (?) of K-feldspar, finely polycrystalline globular aggregates of a low-birefringence, Al-free and $\mathrm{Si}$-rich $\mathrm{Mg}$-silicate with an $\mathrm{Mg} / \mathrm{Si}$ atomic ratio close to 0.5 (palygorskite/sepiolite), and partly altered $\mathrm{Mg}$-Fe-diopside and scapolite crystals (Fig. 11A), the latter commonly showing a thin rim of grossular garnet and/or clinozoisite. A conspicuous reaction rim developed around the pebble, essentially along its quartz-rich part (Fig. 10). The rim comprises quartz-calcite intergrowths (former wollastonite?), 

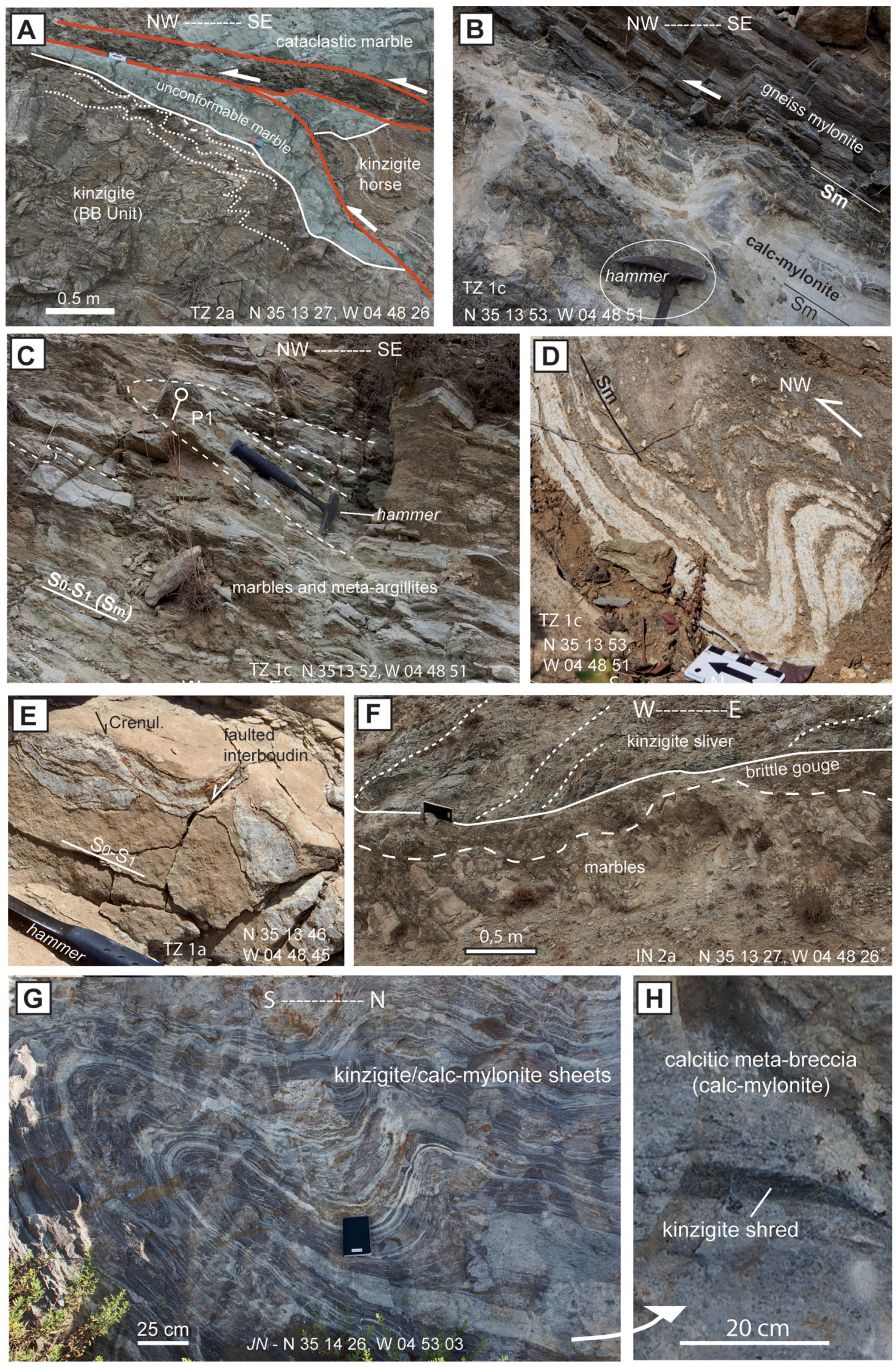
Fig. 7. Structure of marble lenses (see location in Fig. 5, except for $\mathrm{G}$ and $\mathrm{H}$, located in Fig. 4). $\mathrm{S}_{\mathrm{m}}$ : main foliation, which corresponds to bedding $\mathrm{S}_{0}$ transposed in the mylonitic foliation $\mathrm{S}_{1}$. A: Lower boundary of marble lens 2a. B: Upper boundary of marble lens 1c. C: Early isoclinal folds in the lower part of the $1 \mathrm{c}$ lens. Compare with the late folds exposed in a neighboring outcrop (Fig. 6B). D: Northwest verging asymmetric fold in the mylonitic zone on top of the marble lens 1c; the fold deforms boudinaged silica-rich beds (white) interleaved in the carbonate matrix. E: Boudinage and flattening of a silica-rich bed in the marble lens $1 \mathrm{~b}$. Notice the late crenulation and minor fault structures. F: Late normalsinistral fault crosscutting the marble lens $2 \mathrm{a}$ and the overlying kinzigite horse. The fault dips $\sim 40^{\circ}$ to the N. G: Ductile, multiple folding and brecciation of the $\mathrm{JN}$ marbles about 50 meters to the north of outcrop (Fig. 6E). The dark sheets and shreds are composed of kinzigite-like material, the white sheets and the breccia matrix correspond to calc-mylonite. H: Detail of the calc-mylonitic meta-breccia in the core of the major isoclinal fold shown in $(\mathrm{G})$, a few meters to the north.

$\mathrm{K}$-feldspar, sodic plagioclase and diopside in a fine-grained groundmass of Mg-Si-rich sheet-silicate (palygorskite?).

In a more common, less obviously metadetrital marble type such as sample SR123, collected $\sim 50 \mathrm{~m}$ to the north of MTS5 along the same outcrops of the Oued Amter dirt road south of Taza, a coarse-grained calcite groundmass bears abundant phlogopite lamellae and minor scapolite (Fig. 11B), titanite, diopside, and graphite, with accessory pyrrhotite and zircon, and rare thorian uraninite. Titanite is Al-F bearing (up to $\sim 20 \mathrm{~mol}_{0} \mathrm{CaAlSiO}_{4} \mathrm{~F}$ ) and consistently shows reddish-brown to colorless inverse pleochroism. Similar samples may bear less or no phlogopite in the calcite matrix but commonly contain isolated K-feldspar grains (clasts?) and, less commonly, isolated quartz grains, usually rimmed by diopside or (e.g., Jnane Nich, Fig. 11C, D) wollastonite and grossular. Tremolite \pm talc, albite \pm zoisite, chlorite/vermiculite and muscovite are late products of incipient retrogression of diopside, scapolite, phlogopite and K-feldspar, respectively (Fig. 11H); prehnite and zeolites are even later, very minor products.

Dolomitic marbles were found in all outcrops except Jnane Nich, e.g., MTS21 in Taza 1c, MTS13 and MTS15 in Inoualine 2b, SR 138 in Oued Ljouj. The dolomite \pm calcite matrix typically bears forsterite (XMg $=0.98$ to 0.99$), \mathrm{Mg}$-Al-spinel (XMg typically 0.96 to 0.98$)$, phlogopite $(\mathrm{XMg}>0.99)$ and geikielite (ideally $\mathrm{MgTiO}_{3}, \mathrm{XMg} 0.65$ to 0.87 ). Rutile is rare, probably late (Fig. S2 in SM); apatite, pyrrhotite/pyrite and an $(\mathrm{Mg}, \mathrm{U}, \mathrm{Th})$-rich zirconolite (ideally $\mathrm{CaZrTi}_{2} \mathrm{O}_{7}$ ) are synmetamorphic accessories, with occasional baddeleyite $\left(\mathrm{ZrO}_{2}\right)$, generally rimmed or overgrown by tiny zircon (Fig. S3 in SM). A single grain of srilankite $\left(\mathrm{ZrTi}_{2} \mathrm{O}_{6}\right.$, bearing minor $\mathrm{Ca}$, Th, $\mathrm{U}$ and Al) was observed, associated with zirconolite in sample MTS21 (Fig. S4 in SM), which is the first report of srilankite in metacarbonate. Dolomite exsolution in calcite is a common feature and both carbonates consistently bear up to $1 \mathrm{~mol} \%$ $\mathrm{SrCO}_{3}$; exsolution of tiny strontianite blebs from calcite was observed in MTS15. Diopside is now conspicuously absent in the matrix of dolomite marbles but must have been an early (prograde?) phase, as shown by a few tiny diopside inclusions $(\mathrm{XMg} \sim 1)$ in forsterite and by pseudomorphic aggregates of calcite + (serpentinized) forsterite in the dolomitic groundmass (in SR138, Fig. 11G, and Fig. S5 in SM). Partial retrogression and hydration is observed in many samples with serpentinization of forsterite, chloritization or vermiculitization of phlogopite, chlorite overgrowths on spinel, faint talc and tremolite development. The green phyllitic layers locally interleaved in the dolomite marble are made up of a muddle of twisted chlorite-vermiculite lamellae (after phlogopite) with minor fine-grained dolomite and talc.
Within calcite marbles, up to $5 \mathrm{~cm}$ thick boudinaged, massive siliceous layers occur in several outcrops (e.g., Figs. 7D-E). The whitish siliceous layers in outcrop 1a along the Amter road (Fig. 5; sample MTS1, included in a marble bed next to SR 123) mainly consist of diopside (partly altered to talc), epidote, and scapolite (partly altered to albite + zoisite). Small wollastonite bundles partly altered to calcite + quartz occur between the siliceous layer and host marble (Fig. 11E). The white marble samples collected at the Jnane Nich outcrop (JN, Fig. 4) are characterized by dark, boudinaged siliceous layers. These consist of K-feldspar, quartz, plagioclase, diopside, titanite, zircon (Fig. 11C, D). Chalcopyrite grains are surrounded by wollastonite and grossular.

The metamorphic conditions attained by the marbles may be conveniently addressed in the classical $\mathrm{CaO}-\mathrm{MgO}-\mathrm{Al}_{2} \mathrm{O}_{3}-$ $\mathrm{SiO}_{2}-\mathrm{H}_{2} \mathrm{O}-\mathrm{CO}_{2}$ system, extended to include $\mathrm{TiO}_{2}$ and $\mathrm{ZrO}_{2}$ in order to account for the rich accessory mineralogy of dolomite marbles. The absence of tremolite, talc and muscovite in the main marble parageneses points to formation temperatures in excess of $600^{\circ} \mathrm{C}$, for any pressure and mole fraction of $\mathrm{CO}_{2}$ $\left(\mathrm{XCO}_{2}\right)$ in the fluid (e.g. Bucher and Grapes, 2011), which is consistent with dolomite exsolution from calcite and the abundance of Ca-rich, S-Cl-poor scapolite. The presence of geikielite in all dolomitic marbles further constrains the conditions to $T>650^{\circ} \mathrm{C}$, and that of baddeleyite (e.g. in MTS15 dolomite, fringed by zircon and zirconolite) probably to $T>700^{\circ} \mathrm{C}$ (Ferry, 1996; Ferry et al., 2002). The relatively low $\mathrm{F}$ and $\mathrm{Ti}$ content in phlogopite does not point to temperatures approaching or exceeding $800^{\circ} \mathrm{C}$, nor does the scapolite composition (ca. $80 \mathrm{~mol} \%$ meionite) in the calcite marbles, which suggests $T \leq 750{ }^{\circ} \mathrm{C}$ ( $c f$. Ellis, 1978). These conditions are confirmed by the results of calcite-in-forsterite thermometry (Fig. S6 in SM), which show a high-temperature peak at $740-750^{\circ} \mathrm{C}$. A key indicator in dolomite marbles is the relative stability of diopside + dolomite (on the low- $T$, high- $P$ side) versus forsterite + calcite, e.g., above $1.5 \mathrm{kbar}$ at $600^{\circ} \mathrm{C}$ and above $4.5 \mathrm{kbar}$ at $750{ }^{\circ} \mathrm{C}$ (Bucher and Grapes, 2011, their Fig. 6.14). Aggregates of calcite + forsterite (altered to serpentine; Fig. 11G, and Fig. S5 in SM) in dolomite show that diopside formed and then became unstable in these rocks. The relatively coarse-grained texture of these pseudomorphic aggregates and the presence of dolomite exsolution from calcite in the pseudomorph (Fig. S6) indicate that this replacement took place at high $T$, compared to the much later features of incipient breakdown (serpentinization, chloritization, etc.), and at relatively low $P(\leq 4.5 \mathrm{kbar}$, forsterite + calcite stable). 

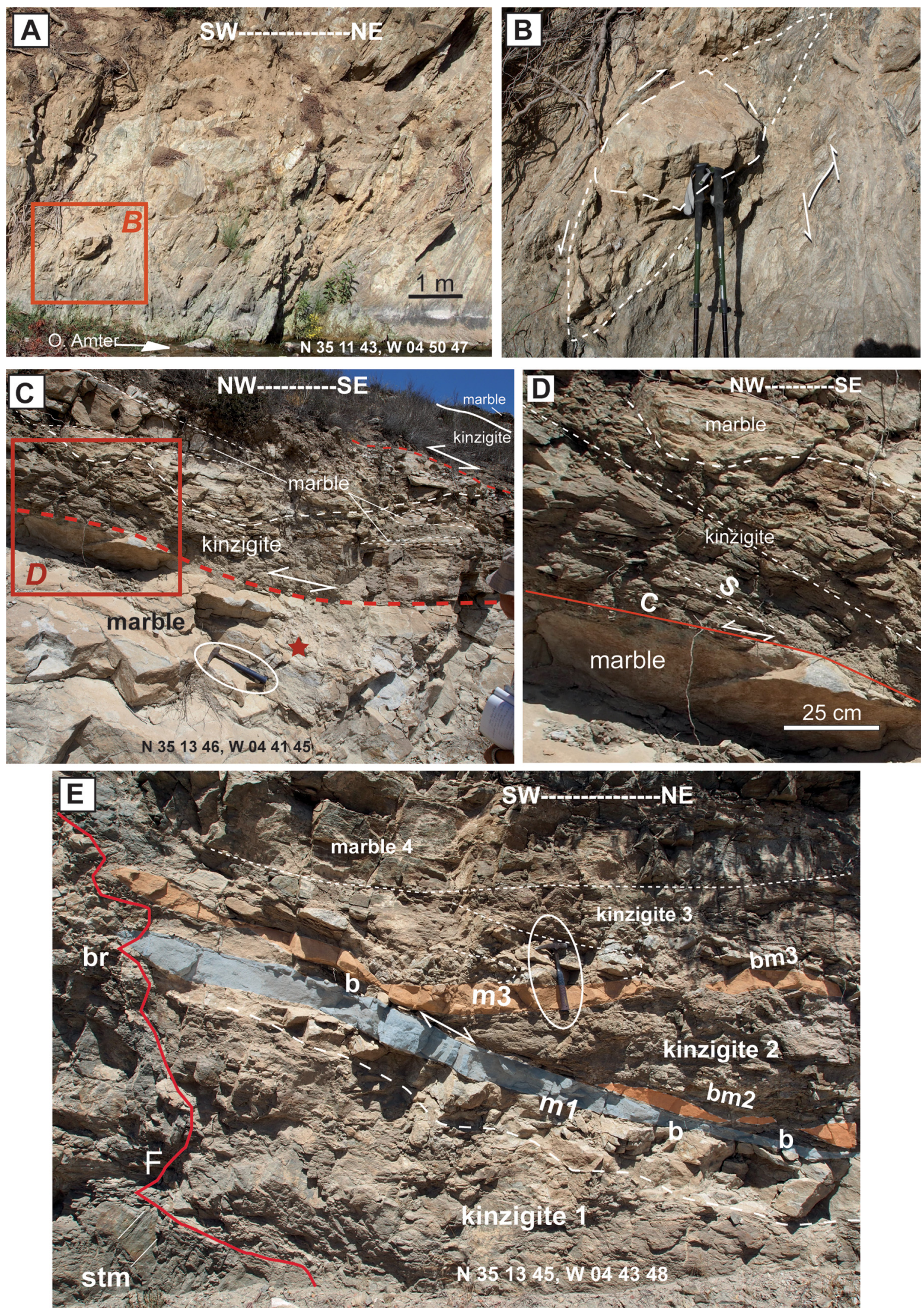
Fig. 8. Field views of some outcrops from the FBBSZ. A: Vertical cliff along the river with exposure of highly sheared kinzigites at Oued Ljouj (location: OL, Fig. 4). The Filali gneisses crop out a few ten meters to the left. B: Close view of a lens-shaped boudin of siliceous marble with brittle-ductile pressure-shadows framed in (A). Half arrows: C planes of S/C structures. Walking poles for scale. C: Lower part of the marble outcrop " $1 \mathrm{~b}$ " exposed along the Amter track (see Fig. 5 for location). The 20 m-thick lens-shaped $1 \mathrm{~b}$ outcrop exhibits three main packages of marbles separated from each other by kinzigites. Hammer for scale. Red star: location of Figure 7E. D: Detail of the kinzigite-marble contact framed in (C). Notice the westward sense of shear indicated by the S/C structures. E: Minor marble-kinzigite packages piled up half-way between "1a" and "1b" along the Amter track (Fig. 5 for location). The top of the lowest marble layer "m1" is shown in light blue, the intermediate layers "m2" and " $\mathrm{m} 3$ " in light orange, the uppermost marble lens " $\mathrm{m} 4$ " is not stained. Notice the ductile boudinage (b) of the blue and orange layers. F: Steep brittle fault associated with marble breccia (br) and striated mirror (stm).

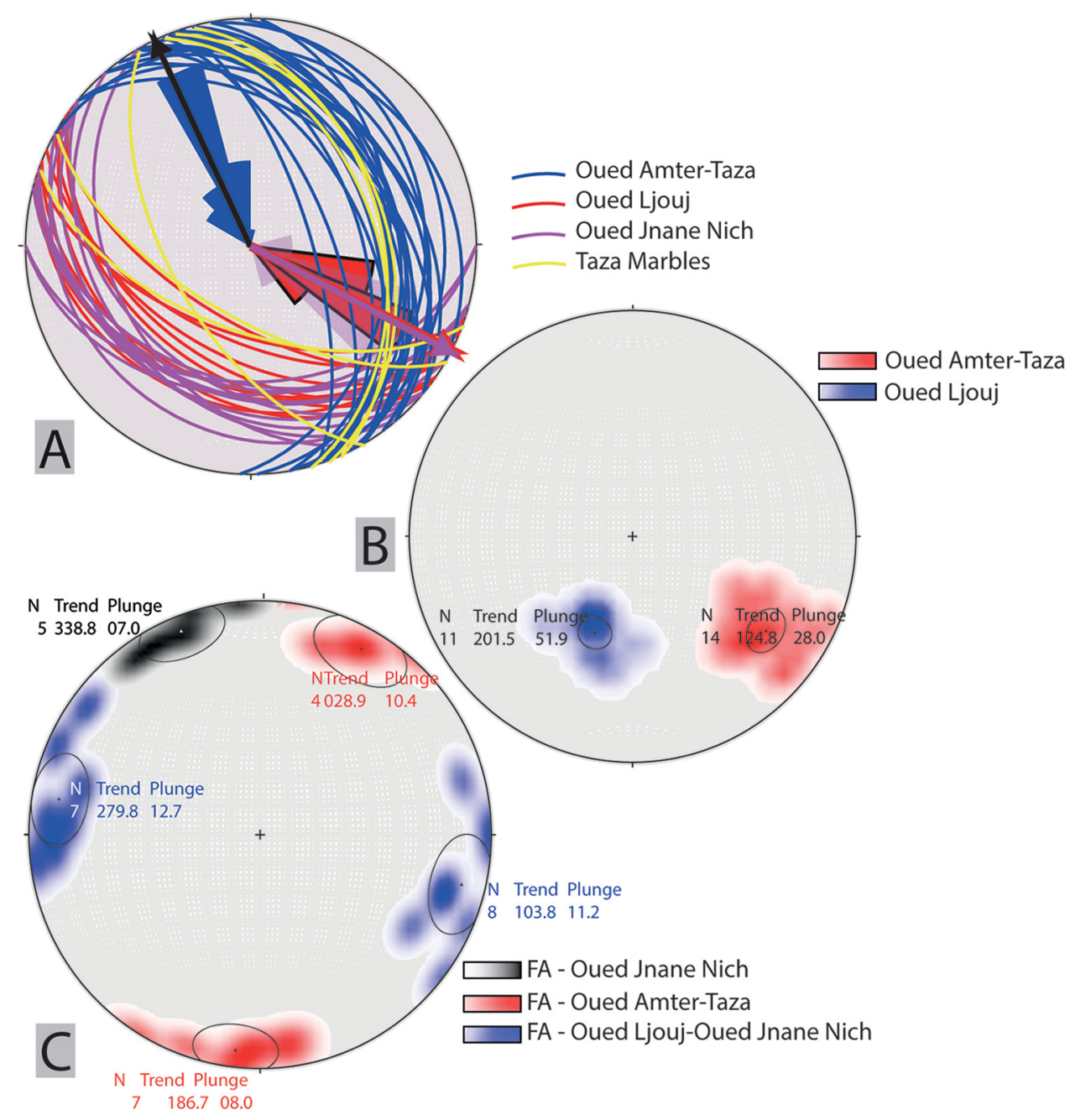

Fig. 9. Stereoplots of foliation $\mathrm{S}_{\mathrm{m}}(\mathrm{A})$, stretching lineations (B), and fold axes (C). Lower-hemisphere equal-area projection. Location of the cited areas in Figures 4 and 5 .

\subsection{SHRIMP U-Th-Pb results}

The typical aspect of the mounted zircon grains under cathodoluminescence (CL) is illustrated in Figure 12. The results are presented hereafter for each dated sample in the form of density distribution and Wetherill Concordia diagrams (Fig. 13), whereas the complete analytical data are provided as Supplementary Material (Table S1 in SM).

\subsubsection{MTS5}

Zircons from this sample are short to medium prismatic, with rounded pyramidal terminations and average 100 $200 \mu \mathrm{m}$ in length. Under cathodoluminescence (CL), most zircons are grey, with patchy zoning or a faint oscillatory zonation. Many of these grains show relict cores of different sizes and shapes, usually rounded and light, whereas overlying 


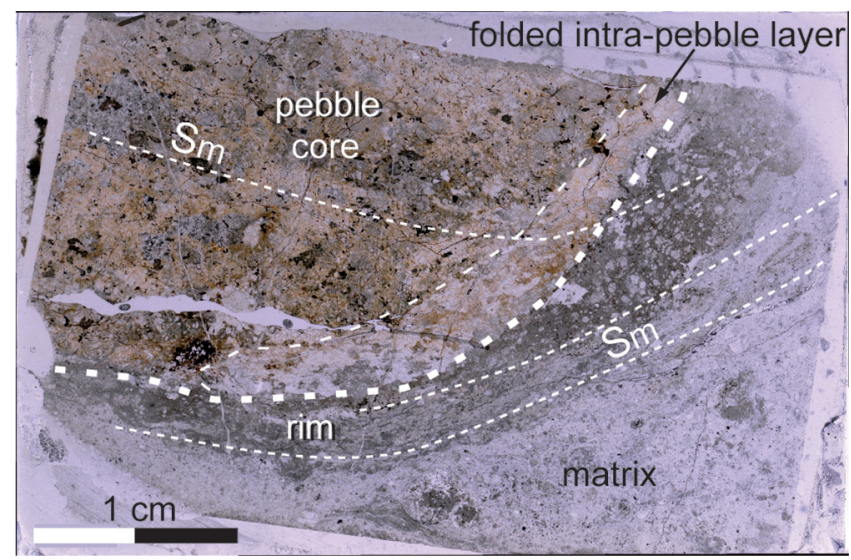

Fig. 10. Overview of a thin section across one of the flattened pebbles (sample MTS5) of the bed shown in Figure 6D. $\mathrm{S}_{\mathrm{m}}$ : regional foliation molded on the pebble in the pressure shadow. The matrix is calciterich, whereas the pebble shows a feldspar-rich brownish part and a quartz-rich, lighter layer. The dark, foliated aureole (rim) around the pebble mainly consists of quartz-calcite intergrowths.

rims are darker, have no internal structure or just a weak zonation (Fig. 12).

We performed 62 analyses in 59 grains. Except for younger ages, most of the rest are concordant, and only four were rejected because of high discordance $(\%$ discordance $=100 \times$ $\left[\left({ }^{207} \mathrm{~Pb} /{ }^{235} \mathrm{U}\right.\right.$ age $)-\left({ }^{206} \mathrm{~Pb} /{ }^{238} \mathrm{U}\right.$ age $) /\left({ }^{207} \mathrm{~Pb} /{ }^{235} \mathrm{U}\right.$ age $\left.)\right]$ and three for being probably mixed ages. The age distribution is almost unimodal (Fig. 13A1) with a maximum of $\sim 21 \mathrm{Ma}$ and older ages with small peaks and isolated ages up to $717 \mathrm{Ma}$. The Alpine ( $21 \mathrm{Ma})$ population is well-defined by 33 analyses. A few are discordant, defining a common-lead discordia with an intersection age of $21.72+0.24 /-0.22 \mathrm{Ma}$. All 33 analyses plot as a consistent cluster over concordia if common-lead is corrected by any common-lead correction method. We then obtain weighted mean ${ }^{206} \mathrm{~Pb} /{ }^{238} \mathrm{U}$ ages of $21.67 \pm 0.18 \mathrm{Ma}(\mathrm{MSWD}=3.1)$ for 208 -correction method, $21.77 \pm 18 \mathrm{Ma}(\mathrm{MSWD}=2.4)$ for the 204-correction method, and $21.58 \pm 0.18 \mathrm{Ma}(\mathrm{MSWD}=2.6)$ for the 207-correction method (Fig. 13A3); all ages are within errors of the intersection age. These Alpine ages were obtained in either uniform grains (Fig. 12, zircon 1) or the outer rims of older cores (Fig. 12, zircon 7).

Ages older than the Alpine orogeny range from $\sim 250$ to $\sim 700 \mathrm{Ma}$ and form three poorly defined clusters (Fig. 13A1, A2). The first and best defined comprises 7 points in the range of 250-283 Ma, yields a mode of $\sim 270 \mathrm{Ma}$, and represents the main relict population. A further 8 points fall in the range of 420-515 Ma (Fig. 13A1, A2). Two analyses, younger than $250 \mathrm{Ma}$ and near concordant ages, likely resulted from lead loss and/or mixed ages between a $270 \mathrm{Ma}$ core and a very close to concordia $21 \mathrm{Ma}$ rim. These older than Alpine ages were obtained in entirely inherited zircons (Fig. 12, zircons 2 and 3) or in inherited cores that were partially transformed during Alpine metamorphism (Fig. 12, zircons 4, 5, 6, and 7).

\subsubsection{MTS6}

Zircon grains from this sample form medium to long prismatic morphologies with rounded pyramidal terminations and average $100-150 \mu \mathrm{m}$ length. They are light-colored, clear and free of inclusions or fractures. Under CL (Fig. 12), most appear as uniform light grey grains with no internal structure or just with faint oscillatory zonation. Some of these zircons contain a relict inner core, which is usually rounded and, in many cases, too small for analysis. Other zircons are darker, with or without zonation, and most contain an irregular inherited core (Fig. 12).

Seventy-one analyses were carried out in 46 grains. Six yielding very discordant or apparent mixed ages were rejected. The remaining 65 analyses mainly fall into two main groups: one population peaks at $\sim 21 \mathrm{Ma}$ and the second, and statistically more important, peaks at $\sim 270 \mathrm{Ma}$ (Fig. 13B1). There is also a smaller group of analyses of Variscan age (Fig. 13B2). Isolated older inherited ages appear up to $2644 \mathrm{Ma}$. The Alpine population comprises 11 analyses. Some have a variable common-lead content and align in a commonlead discordia line yielding an intersection age of $22.30+0.67 /$ $-0.8 \mathrm{Ma}$. Uncorrected and corrected for common-lead by the 207-correction method, they yield more precise weighted mean ${ }^{206} \mathrm{~Pb} /{ }^{238} \mathrm{U}$ ages of $22.75 \pm 0.48$ and $22.54 \pm 0.48 \mathrm{Ma}$ $(M S W D=3.7)$. These Alpine ages were obtained in rims mantling inherited cores (Fig. 12, zircons 1, 2, 3, and 6) or rarely in almost entirely transformed, Alpine grains (Fig. 12, zircon 8).

Pre-Alpine ages are mainly Permo-Triassic, but there is a small Carboniferous population, and older isolated points (Fig. 13B1, B2). Permo-Triassic ages are, by far, the more abundant in this sample. Thirty-one analyses fall between 227 and $290 \mathrm{Ma}$ and yield a mode of $270 \mathrm{Ma}$ with a weighted mean ${ }^{206} \mathrm{~Pb} /{ }^{238} \mathrm{U}$ age of $266 \pm 7 \mathrm{Ma}$. The distribution of this population is not symmetric, being tailed to the younger ages. This explains the high error of the average. These ages are found at any location inside the grains: in unzoned grey rims over inherited cores of different ages (Fig. 12, zircons 4, 5, and 7), in relict cores mantled by Alpine rims (zircons 1, 3, and 6) or even in entirely uniform grains. The Carboniferous population comprises a small, nearly concordant but not very consistent cluster peaking at $\sim 340 \mathrm{Ma}$ (Fig. 13B1, B2). These ages always appear in inherited cores of variable size and shape, mantled by Permo-Triassic, or less frequently, by Alpine age rims (Fig. 12, zircons 2 and 4).

\subsubsection{MTS18}

Zircons from this sample are short to medium, prismatic or round, always with rounded terminations, and are, generally, relatively short (averaging $<100 \mu \mathrm{m}$ ). Most of the grains are heterogeneous in age, with discordant rims over irregular cores. A few are uniform, with no internal structure (Fig. 12). Fifty-seven analyses were performed in rims and cores of 52 grains. Eleven had a discordance $>10 \%$ and were rejected for age calculations. The remaining 46 analyses show a polymodal distribution with a main peak at $273 \mathrm{Ma}$, smaller peaks at $\sim 457,584,813 \mathrm{Ma}$, and isolated old ages up to $3088 \mathrm{Ma}$ (Fig. 13, C1 and C2). No Alpine ages are recorded in this sample. Fifteen analyses plot in the range of 220-320 Ma and define a wide cluster yielding a mode at $273 \mathrm{Ma}$ and a weighted mean ${ }^{206} \mathrm{~Pb} /{ }^{238} \mathrm{U}$ age of $273 \pm 14 \mathrm{Ma}$. This population shows a symmetric distribution, so mode and mean are coincident, but the mean age error is large because of the high 

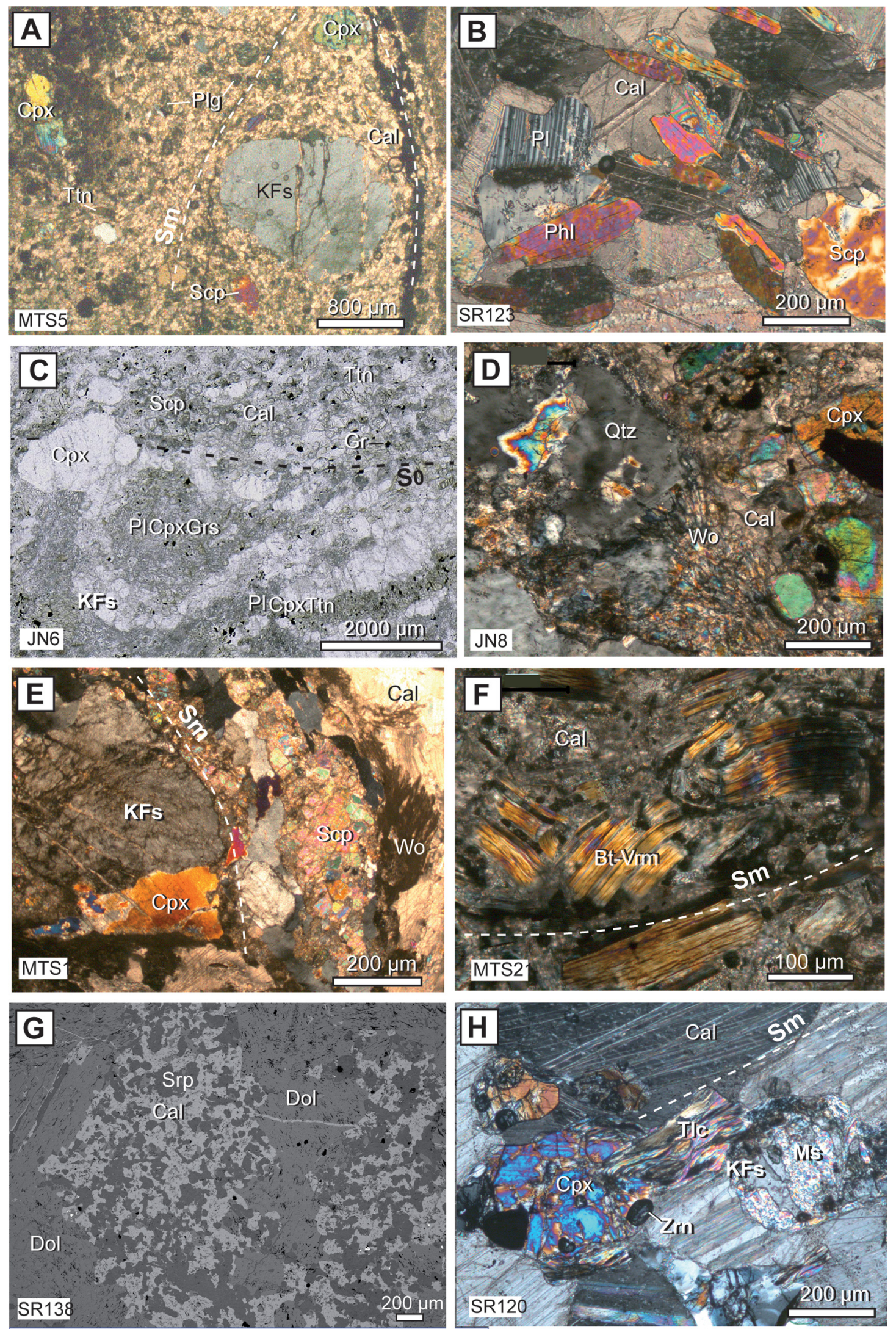
Fig. 11. Micrographs of some BBMs samples. For location of the corresponding outcrops, see Figure 4 (JN) and Figure 5 (other samples). Crossed nicols except $(\mathrm{C})$, plane-polarized light, and $(\mathrm{G})$, backscattered-electron image. $\mathrm{S}_{\mathrm{m}}$ : main foliation. A: Metadetrital, pebbly marble from the Amter road (outcrop 1a), $\sim 1 \mathrm{~m}$ above the unconformity (Fig. 6C). B: Magnesian marble from the same road-cut, $\sim 50 \mathrm{~m}$ above (A) (marble lens 1b). C: Metadetrital banded marbles of Oued Jnane Nich lens (JN, Fig. 4); the dashed line marks the limit between two elementary layers, calcite-rich and clastic-free, respectively, interpreted as $\mathrm{S}_{0}$. D: Same outcrop, calc-mylonite facies. E: Calc-silicate bed, likely clastic and including minute pebbles (left area); same location as (B). F: Meta-argillite layer interbedded with banded marbles (lens 1c). G: Dolomite-rich calc-silicate bed (Oued Ljouj lens). The aggregates of calcite + serpentinized forsterite in dolomite matrix are interpreted as calcite + forsterite pseudomorphs after diopside. H: Banded phyllitic marble, same outcrop as (F); talc and muscovite are retrograde.

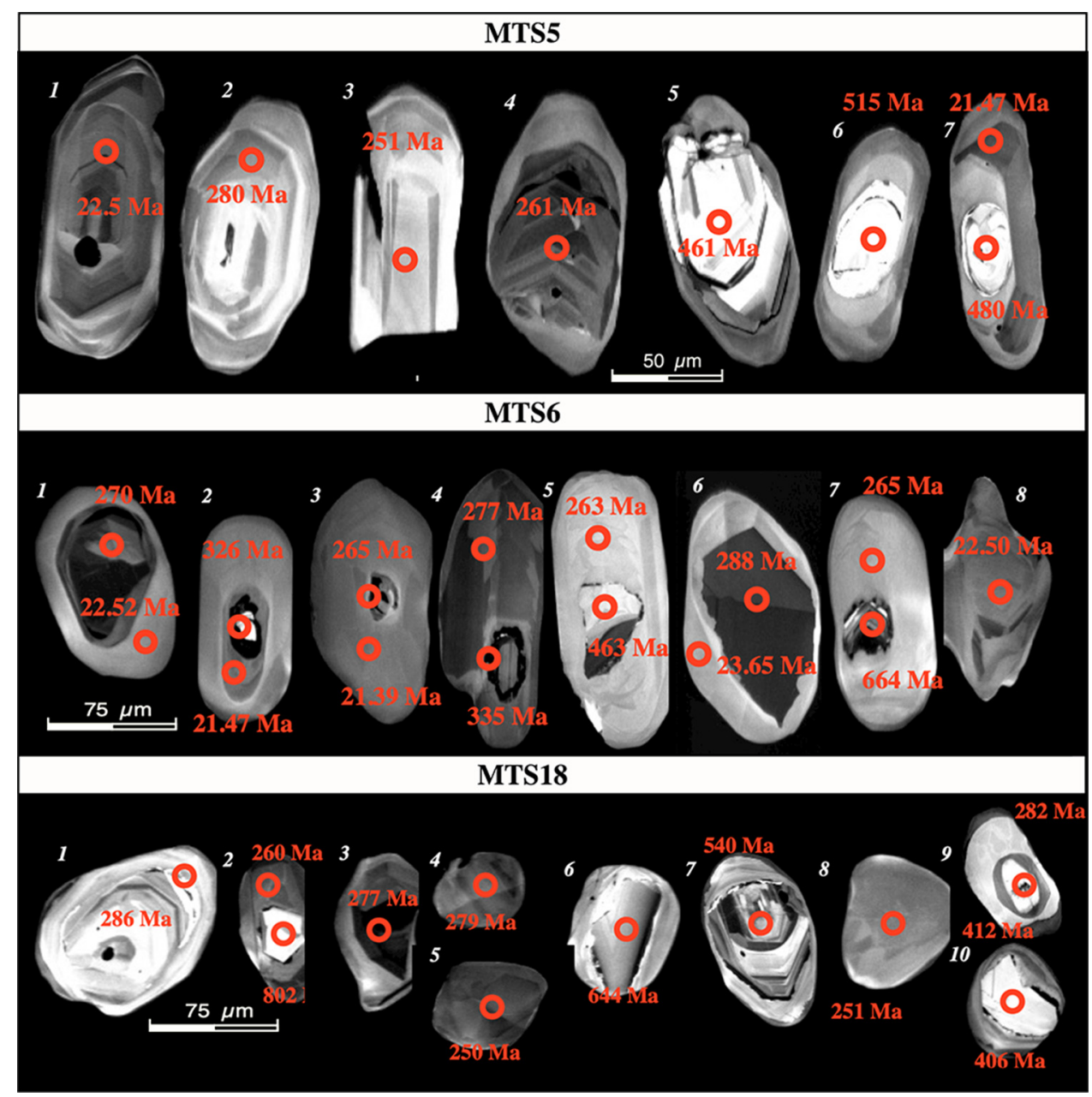

Fig. 12. CL images of selected zircons from samples MTS-5, MTS-6 and MTS-18.

dispersion. These Permo-Triassic ages are found in rims (Fig. 12, zircons 1, 2, and 9), in cores (zircon 3), and uniform grains (zircons 4, 5, and 8). Between 350 to $700 \mathrm{Ma}$ ages plot in an almost continuum, with small and poorly defined groups having low statistical significance. A separate small group of analyses peak at $813 \mathrm{Ma}$. These pre-Permian ages are mainly found in inherited cores (Fig. 12, zircons 2, 6, 7, 9, and 10) and rarely in entire grains.

\section{Interpretation and discussion}

\subsection{The marble protoliths}

Since J. Kornprobst's fundamental work (1974) the Beni Bousera marbles have been regarded as calcareous interca- lations in the metapelitic series, protolith of the kinzigites. This hypothesis, although not supported by the mapping of marble occurrences, has never been questioned until recently (Saddiqi et al., 2019; Michard et al., 2020a). In fact, three lines of observation now change this perception.

Firstly, the marbles are nowhere observed in the central mass of the kinzigites. By contrast, all the marble bodies are concentrated in the contact zone between the Beni Bousera and Filali units, i.e., the FBBSZ (Fig. 4). As reported above (Sect. 4.2), this shear zone is characterized by mylonitic, HT deformation (e.g., Fig. 7B, G, Fig. S1 in SM) with secondary duplexes and tectonic slivers, which frequently bring kinzigite bodies on top of marbles sequences (Figs. 6C, E and 7A). These tectonic imbrications are distinct from sedimentary intercalations of carbonates in a pelitic series at the origin of 

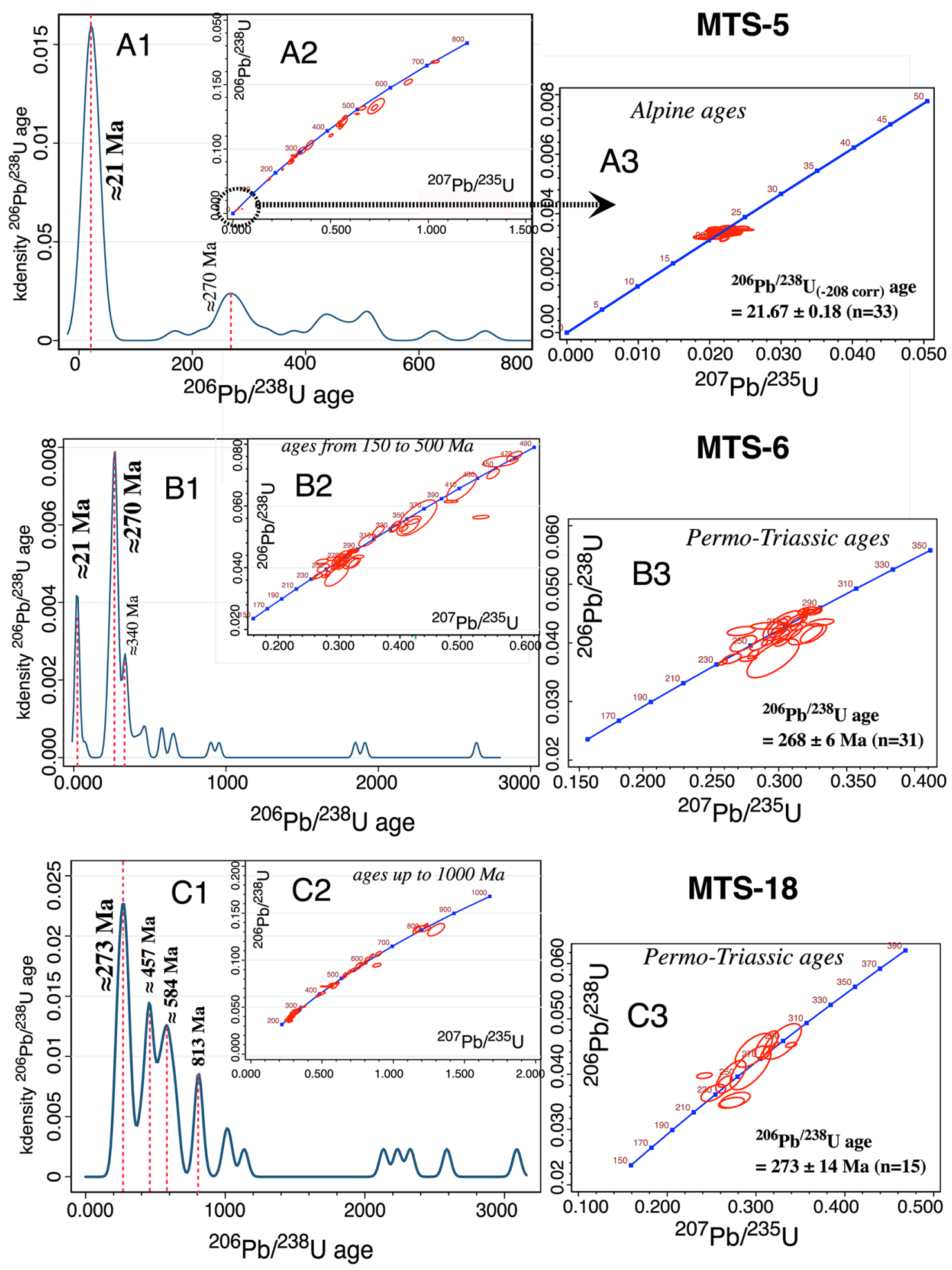

Fig. 13. Density distribution and Wetherill Concordia diagrams for U-Th-Pb dated zircons from samples MTS5, MTS6 and MTS18. A1, B1 and $\mathrm{C} 1$ are kernel density plots. A2 shows the Concordia of the whole dataset for sample MTS5 and A3 shows only the younger population with the weighted mean ${ }^{206} \mathrm{~Pb} /{ }^{238} \mathrm{U}$ age calculation. B2 contains a Concordia between 150 and $500 \mathrm{Ma}$ to show only the main age groups in sample MTS6. B3 shows the Permian-Triassic population and the age calculation in the same sample. C2 contains a Concordia up to 1000 Ma to show the main age groups in sample MTS18, and C3 shows the Permo-Triassic population with age calculation. 
the kinzigites. In the case of the Oued Jnan Nich outcrop, the southern part of the marbles contains folded, boudinaged silicate layers whose texture and mineralogy are compatible with a detrital origin (Fig. 11C). In contrast, the northern, lower part of the marbles displays mingled kinzigite-like and calcmylonite sheets folded together (Fig. 7G), which may be explained by the occurrence of calcareous beds within the pelitic protolith of the kinzigites. However, at this time, we prefer a hypothesis involving tectonic mingling in the frame of the HT mylonitic deformation that prevails along the FBBSZ.

Secondly, a sharp, unconformable contact is observed in two outcrops (marble lenses 1a and 2a, Fig. 5) between the kinzigites of the Beni Bousera Unit and the overlying marble beds (Figs. 6C and 7A). As stated above, the nature of these sharp contacts is ambiguous: they may be either stratigraphic unconformities or low-angle detachment contacts. In any case, these contacts are at odds with a hypothesis of initial continuity between carbonates and pelites before the granulite-facies metamorphism that affected the kinzigites during the Variscan orogeny (Rossetti et al., 2020).

Thirdly, petrologic evidence may negate the intercalation hypothesis. If the marbles shared the history of the kinzigites, they should bear evidence of both (i) the Alpine overprint dated at 21-22 Ma (Rossetti et al., 2020), which produced retrograde cordierite-spinel-sillimanite in the kinzigites at conditions near 4-5 kbar, $650-750{ }^{\circ} \mathrm{C}$ (El Maz and Guiraud, 2001), and (ii) peak granulite-facies conditions attained by the kinzigites during Variscan times (290-300 Ma; Rossetti et al., 2020) and estimated at $\sim 800^{\circ} \mathrm{C}, 12-15$ up to 20 kbar by Bouybaouene et al. (1998), $800-870^{\circ} \mathrm{C}, 10.5-13 \mathrm{kbar}$ by $\mathrm{El} \mathrm{Maz}$ and Guiraud (2001), or $900-950^{\circ} \mathrm{C}, 12-14 \mathrm{kbar}$, down to $850{ }^{\circ} \mathrm{C}$, 11-13 kbar by Rossetti et al. (2020). Under these granulitefacies peak conditions, with a fluid likely to be $\mathrm{H}_{2} \mathrm{O}$-poor $\left(\mathrm{XCO}_{2}>0.5\right)$, the stable assemblage in dolomite marbles would be corundum + diopside + dolomite, which, upon decompression, would grade into spinel + diopside + dolomite \pm calcite and finally into spinel + forsterite + dolomite + calcite. On the other hand, along a low- $P$ prograde path with an initial fluid likely to be $\mathrm{H}_{2} \mathrm{O}$-rich $\left(\mathrm{XCO}_{2}<0.3\right)$, such marbles would be expected to bear successively chlorite \pm tremolite \pm diopside, and then forsterite and spinel. At $P$ lower than $6 \mathrm{kbar}$ and whatever fluid composition, corundum has no stability field in such dolomite marble. Considering the refractory nature of corundum, one would expect to find relics of it in spinel in case the dolomite marbles underwent HP granulitefacies conditions before Alpine time (cf. Liati, 1988; Castelli et al., 2007), whereas the absence of corundum is logical in case they had only an Alpine history. We did not find corundum, nor was it reported by Kornprobst (1974). This is regarded as tentative, but not compelling, evidence for a simple prograde low- $P$ evolution of the marbles. In any event, the main forsterite + calcite assemblage developed in spinel dolomite marble is consistent with the LP-HT conditions of an Alpine imprint.

Therefore, based only on these geological/mineralogical arguments, we assume that the BBMs were derived from a sedimentary formation younger than the granulitic envelope of the Beni Bousera Unit (as demonstrated below by the U-Pb zircon results; see Sect. 5.2.2), and that they were either deposited unconformably upon it or carried onto it by some type of fault, prior to the marble metamorphism.
The protolith of the conglomeratic marble (in Amter 1a) could be a detrital limestone with pebbles from a garnet gneiss source and possibly mafic-ultramafic sand-size input as suggested by the globular aggregates of palygorskite/sepiolite in the calcite groundmass (Sect. 4.3). The protoliths of the dolomitic marbles could be dolomites or dolomitic limestones with a minor detrital fraction, locally interleaved with thin argillite beds (now forming green phyllitic layers). The protolith of the massive whitish siliceous layers boudinaged in calcite marble (Amter outcrops 1b, 1c) could be cherts or a marly sandstone layers, but the abundance of calc-silicates and the occurrence of a few greenish aggregates (pebbles?) comprising diopside, K-feldspar and titanite rather supports the latter possibility. The protolith of the white marble samples with dark, boudinaged siliceous layers at Jnane Nich could again have been immature calcareous sandstones.

The lithology of the carbonate formation before metamorphism is therefore characterized by shallow marine facies, such as dolomitic limestones and dolostones, sandstones, clastic limestones with sandstones layers and rare argillites. The coarse clastic, pebbly marbles located just above one of the marbles basal contacts (Fig. 6A), apparently support the notion of unconformable sedimentation on top of the kinzigites. However, the K-feldspar clasts and the pebbles bearing quartz, K-feldspar and almandine may have a different origin than the underlying kinzigites, possibly a source similar to the Filali garnet-bearing gneisses. As for the globules of palygorskite/sepiolite scattered in some of the clastic marbles (e.g., Fig. 11A), they could form from the retrogression of metamorphic forsterite (Fo 98\% in sample MTS13; Tab. 1) rather than from detrital olivine sourced from the peridotites (Fo 90\%; Obata, 1980). Therefore, in contrast to previously expressed (Saddiqi et al., 2019; Michard et al., 2020a), the idea of transgression upon an exhumed Beni Bousera Unit cannot be presently ascertained. An alternative hypothesis, which proposes a tectonic emplacement of the marbles onto the kinzigites, also requires further discussion (Sect. 5.3).

\subsection{Age of the marble protoliths}

\subsubsection{Lithostratigraphic comparisons}

Middle-Upper Triassic dolomitic carbonates characterize the four Federico units superimposed in the Beni Mezala antiform west of Ceuta (Fig. 1; Durand-Delga and Kornprobst, 1963) and their equivalent in the western Betics (CasaresBenarraba imbrications; Balanyá et al., 1997; Sanz de Galdeano et al., 1999). Similar facies are better developed in the western and central Alpujarrides in several mountains named after their white cliffs, such as the Sierra Blanca and Sierra de Las Nieves (see Fig. 16 below). These carbonate series are less recrystallized in units to the east than in the west. In the eastern Alpujarrides nappes, the Sierra de Gador (Fig. 1 for location) exposes a low-grade, $1500 \mathrm{~m}$ thick series, which begins with alternating phyllites, quartzites and scarce limestones (Anisian?) and continues upward with Ladinian to Carnian carbonates and subordinate marls (Martin-Rojas et al., 2009, 2012). Dolomite is essential in the lower Ladinian member, and syn-sedimentary normal faults are wellillustrated during the Ladinian. The Sierra de Gador series records a faulted platform formed during the rifting of Pangea, 
as the Briançonnais and South Alpine coeval series (MartinRojas et al., 2012). In contrast, the Ghomarides-Malaguides domain is typified by red beds (Verrucano) facies during the Anisian-Carnian span of time (see Sect. 2, and Perrone et al., 2006). The Casares-Benarraba, which are the Betic equivalent of the Federico units, can be regarded as transitional between the Malaguides and Alpujarrides domains (Sanz de Galdeano et al., 1999, 2006). As the Beni Bousera-Ronda units belong to the typical Alpujarride-Sebtide domain, we may at first suggest a Middle-Late Triassic age for the BBMs. However, the occurrence of younger deposits (Early Jurassic?) cannot be excluded for thinly-bedded facies such as those illustrated in Figure 6B.

\subsubsection{Zircon dates}

The SHRIMP U-Th-Pb analyses of zircon collected from three marble samples at different outcrops in the Taza and Inoualine areas (Fig. 5, outcrops 1a, 1c, 2b) yielded convergent dates, i.e., $\sim 21 \mathrm{Ma}$ in the most external rims and $\sim 270 \mathrm{Ma}$ or older dates in the core of the grains (Sect. 4.4; Figs. 12 and 13). The Alpine, $\sim 21 \mathrm{Ma}$ date can be clearly ascribed to the HT-LP event that affects the marbles, as well as the kinzigites and the overlying Filali Unit (Rossetti et al., 2010, 2020; Gueydan et al., 2015). The scatter of dates from $\sim 270 \mathrm{Ma}$ to $\sim 3000 \mathrm{Ma}$ (Fig. 13) from zircon cores suggests a detrital origin for these grains. Archean and Paleoproterozoic dates are compatible with Gondwana sources, consistent with the location of the Alpujarride-Sebtide domain between Iberia and Africa during the Mesozoic (Figs. 2B, C). Mesoproterozoic dates around $1000 \mathrm{Ma}$ are less easily interpreted; they could reveal presently distant, but formerly adjacent sources (Bea et al., 2010), or the erosion of NW-Gondwanian intrusions (Ikenne et al., 2017) or secondary sources such as the oldest deposits of the Taoudenni basin (Bradley et al., 2015). Neoproterozoic dates ( 813 Ma and $584 \mathrm{Ma}$ peaks) could reveal sources from the Pan-African belt of NW Africa and Western Europe (e.g., Soulaimani et al., 2018; Arenas et al., 2020). Paleozoic peaks at $\sim 460$ and $\sim 340$ can be linked to the Cambro-Ordovician magmatism (Ballèvre et al., 2012; García-Arias et al., 2018) and Carboniferous Variscan orogeny (Michard et al., 2010; Díez-Fernández et al., 2016) of the same regions, respectively.

The well-marked $\sim 270 \mathrm{Ma}$ peak corresponds to the Middle Permian age of a number of rhyolite flows or domes emplaced in extensional-transtensional red bed basins, and to the associated shallow crustal, subalkaline plutons of Morocco and Western Europe (e.g., El Hadi et al., 2006; Chopin et al., 2014; Youbi et al., 2018; Yuan et al., 2020; Zouicha et al., 2021). It is worth emphasizing that this Middle Permian U-Pb age appears specific to the BBMs when compared to $\mathrm{U}-\mathrm{Pb}$ dates published for the AlpujarridesSebtides crustal units. The Beni Bousera kinzigites and the Filali gneiss both record granitic melt ("leptynites") emplacement at 290-300 Ma (U-Pb electron microprobe dating of monazite grains enclosed in garnet, $284 \pm 27 \mathrm{Ma}$, Montel et al., 2000; LA-ICP-MS U-Pb dating of zircon, 290$300 \mathrm{Ma}$, Rossetti et al., 2010, 2020). Similar ages are documented for the Variscan anatectic phase beneath the Ronda peridotites (280-290 Ma, SHRIMP data; Acosta-Vigil et al., 2014) and in the Torrox gneiss of Central Alpujarrides (286 11 Ma, SHRIMP data; Sánchez-Navas et al., 2017).
The 286-264 Ma age proposed by Melchiorre et al. (2017) for the Variscan HP-HT event and subsequent melting in the Beni Bousera kinzigites is based on LA-ICP-MS analyses of a restricted number of zircon grains and is considered tentative. Therefore, we maintain that the $\sim 270 \mathrm{Ma}$ peak recognized in the core of the zircon grains from the BBMs is not a metamorphic age, but rather the younger age cluster of detrital zircons deposited in the marble protoliths. This is consistent with the above proposal of a Triassic age for most of these protoliths.

\subsection{Early exhumation of the Beni Bousera peridotites}

Based on the P-T-t trajectories of the Beni Bousera peridotites and kinzigites, Rossetti et al. (2020) assume that they were broadly coupled during the waning stages of the Variscan orogeny. From this perspective, we may consider the exhumation of the kinzigites (documented by the emplacement of the marble Triassic protoliths over these HP crustal rocks) as a proxy for the exhumation of the peridotites.

\subsubsection{Which mode of emplacement of the Triassic protoliths over the kinzigites?}

On a kilometer scale (Fig. 4), the contact between the Beni Bousera kinzigites and the Filali gneiss, namely the FBBSZ, is a syn-metamorphic low-angle thrust fault locally assisted by the high ductile properties of the calc-mylonites (see the classic example of the Jurassic calc-mylonites beneath the Helvetic nappe of Glarus; Ebert et al., 2007), and affected by the late regional folding and faulting. In contrast, due to the strong metamorphic and tectonic overprint, the nature of the sharp contact locally observed between the marbles and the underlying kinzigites is somewhat ambiguous. As mentioned previously (Sect. 5.1), there may be two alternative interpretations to explain this relationship, either stratigraphic or tectonic. Accordingly, we propose hereafter two alternative scenarios for the early exhumation of the peridotites (Fig. 14). Both are based on the assumption that the lower crust and mantle rocks have been exhumed to the Earth's surface or close to it during the rifting and subsequent extension that progressively opened the Maghrebian (East-Ligurian) and Betic (West Ligurian) oceanic branches of western Tethys during the Middle Triassic-Jurassic (Guerrera et al., 1993; Michard et al., 2002; Molli, 2008; Handy et al., 2010, 2015; Leprêtre et al., 2018).

For the first possible hypothesis (Fig. 14A), we assume that the kinzigites were exposed (and then the peridotites not far from the surface) by the Triassic. Such an early exhumation may seem anomalous, compared with the currently accepted Middle Jurassic age of opening of the Maghrebian-Ligurian Ocean (Bill et al., 2001; Leprêtre et al., 2018; Balestro et al., 2019). However, rifting might have commenced early in the westernmost Maghrebian Ocean, close to the Central Atlantic, whose drifting phase began as early as $195 \mathrm{Ma}$ (Labails et al., 2010)

For the second possible hypothesis (Fig. 14B), we refer to the hyperextension models of the Adria (Manatschal, 2004; Mohn et al., 2010) and Corsica (Beltrando et al., 2013; Seymour et al., 2016) inverted margins, backed on the 
A 1st hypothesis: Unconformity of Triassic deposits onto the kinzigites

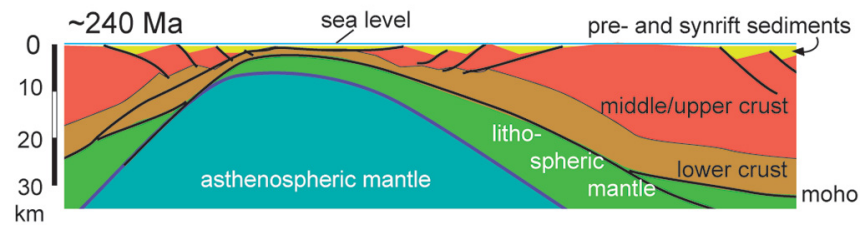

B 2nd hypothesis: Tectonic emplacement of Triassic-Early Jurassic allochthons onto the kinzigites

1) 210-190 Ma: Early rifting, shallow water sedimentation

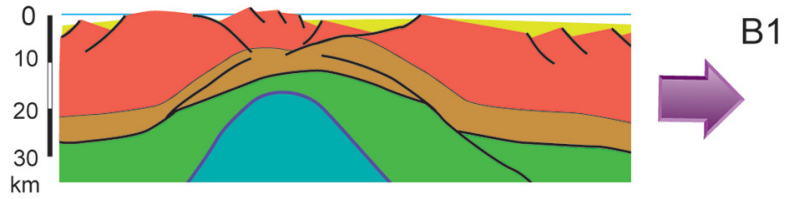

2) 180-165 Ma: Necking, distal margin detachment Triassic allochthon

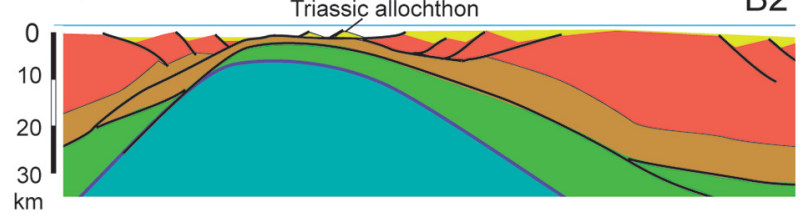

Fig. 14. Alternative models $(\mathrm{A} / \mathrm{B})$ accounting for the occurrence of the BBMs between the Filali and Beni Bousera units. A: Triassic unconformable sedimentation onto the exhumed kinzigites (lower crust). B: Triassic-Early Jurassic extensional allochthons (rafts) emplaced onto the exhumed kinzigites.

description of the non-inverted margins such as the Atlantic Galicia margin (Péron-Pinvidic and Manatschal, 2009). In this hypothesis, the marbles would represent pre- to early syn-rift deposits, detached and fragmented as continental allochthons of the hanging-wall of the detachment fault allowing the lower crust to be exhumed. Thus, the granulitic lower crust would have been bounded by two detachments, the lowest located on top of the lithospheric mantle and the uppermost at the limit of the upper crust. This setting resembles that of the present-day described by Afiri et al. (2011) and Gueydan et al. (2015), but the novelty is that it occurred as early as during Triassic-Early Jurassic time.

With the present state of our knowledge, it would be unwise to definitely make a choice between these two scenarios. In both cases, our proposals are in line with the U-Pb SHRIMP dating of zircons from Ronda garnet pyroxenites and Ojen eclogites at $178 \pm 6 \mathrm{Ma}$ and $183 \pm 5 \mathrm{Ma}$, respectively, interpreted as recording the Tethys opening (SánchezRodríguez and Gebauer, 2000). Rossetti et al. (2020) propose that the isothermal exhumation of the Beni Bousera kinzigites within the cordierite stability field (below 5 kbar) records the Permian collapse of the thermally weakened Hercynian orogen. Based on the occurrence of the BBMs, we propose that the kinzigites were entirely exhumed as early as the Middle Triassic (scenario A, "transgression hypothesis") or the Early Jurassic (scenario B, "raft hypothesis"). If correct, the Beni Bousera peridotites were exhumed to the subsurface as early as the Middle-Upper Triassic or the Early Jurassic, respectively. This timing is in line with Angrand et al. (2020), who argue for a protracted period of $\sim 100 \mathrm{Myr}$ (late Carboniferous to Late Triassic) of continental lithosphere thinning around Iberia.

\subsubsection{Restoring the Alpujarrides-Sebtides-Dorsale paleomargin}

During the Jurassic, the Alboran Domain was located at the southwestern tip of Alkapeca (Figs. 2B-C and 15A), so the Malaguide-Ghomaride and Alpujarride-Sebtide crustal domains extended between the two branches of the Alpine Tethys (East and West Ligurian branches), but their relative position is a matter of debate (Chalouan and Michard, 2004). Many authors argue that the post-Triassic sedimentary series of the Malaguides-Ghomarides are transitional to those of the Dorsale units and assume that the latter detached from the external border of the Ghomarides (e.g., Didon et al., 1973; Sanz de Galdeano et al., 2001; Durand-Delga, 2006; El Kadiri et al., 2009; Guerrera et al., 2019). As the Dorsale series is regarded as having been deposited at the northern margin of the Maghrebian Tethys (Olivier, 1990; El Hatimi et al., 1991; Chalouan et al., 2008; El Kadiri et al., 2006, 2009), the Alpujarrides-Sebtides would have been more internal than the Ghomarides, possibly at the western border of the Betic branch of the Tethys (Fig. 2C right, after Guerrera et al., 2019).

However, Trümpy (1973), Wildi et al. (1977), and Nold et al. (1981) observed that the stratigraphic series of the Sebtides ends with Middle Triassic carbonates whereas that of the Dorsale begins with Upper Triassic dolostones and limestones, suggesting that the Sebtides represent the former basement of the detached Dorsale units. Based on this observation, and in line with Michard et al. (2021), we restore the Alpujarrides-Sebtides in a more distal position than the Malaguides-Ghomarides, at the northern border of the Maghrebian Tethys (Fig. 15B, location is shown in Fig. 15A). This proposal is consistent with the nature and moderate thickness of the crustal rocks that form the Alpujarrides-Sebtides basement, i.e., a few thousand meters of schists, gneiss, and granulites affected by high-grade Variscan metamorphism (see also Zeck and Whitehouse, 1999, 2002; Sánchez-Navas et al., 2017). In this framework, the occurrence of Triassic unconformable deposits or rafts upon the Beni Bousera granulites, as proposed above (Fig. 14), is likely. We assume that the Alpujarrides-Sebtides crustal units were progressively exhumed during the Early Permian collapse of the Variscan belt (Rossetti et al., 2020) and the Late Permian initial rifting of Pangea (Najih et al., 2019), prior to the onset of Middle Triassic sedimentation. Then rifting proceeded up to the Early-Middle Jurassic, as indicated by neptunian dykes in the Dorsale and neighboring MalaguideGhomaride domains (El Kadiri et al., 1992; El Kadiri et al., 2000-2002b), which are coeval with those described in the northern Sila massif of Calabria (Bouillin and Bellomo, 1990).

\subsubsection{Alpine burial and final exhumation}

As described previously, the BBMs have been dramatically disrupted and recrystallized under HT-LP conditions in the ductile basal thrust of the Filali Unit (FBBSZ). As the $P-T$ conditions in the marbles $\left(\leq 4.5 \mathrm{kbar}, \sim 700-750{ }^{\circ} \mathrm{C}\right.$; see Sect. 4.3) are in the same range as those at the base of the 

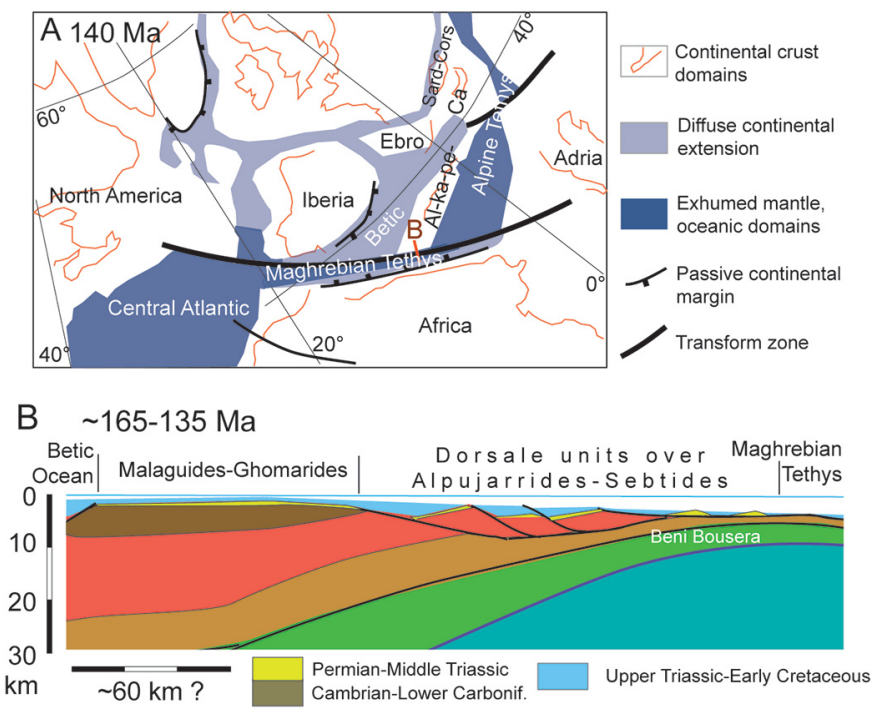

Fig. 15. The hyperextended margin of the Alboran Domain during the Late Jurassic-Early Cretaceous, modified after Michard et al. (2021). A: Location of the Alboran Domain (southern part of Alkapeca) to the north of the Maghrebian Tethys; background map after Angrand et al. (2020), slightly modified. B: Tentative restoration of the Alboran Domain margin whose distal part corresponds to the AlpujarridesSebtides crustal units overlain by the Dorsalian pre- and syn-rift sediments. Crust and mantle signatures as Figure 14.

overlying unit (El Maz and Guiraud, 2001; Rossetti et al., 2010, 2013, 2020; Gueydan et al., 2015), we infer that the carbonate series recrystallized with and beneath the same degree of burial as the Filali rocks during the Alpine orogeny. This is confirmed by the SHRIMP U-Th-Pb $\sim 21 \mathrm{Ma}$ dating of the overgrowths of detrital zircons from the marbles, which are identical to the age of the HT anatectic phase of metamorphism and granite dyke intrusions observed in the Beni Bousera and lower Filali units (Rossetti et al., 2010). However, Homonnay et al. (2018) showed that Alpine metamorphism began prior to $\sim 28 \mathrm{Ma}$ when the Sebtides were involved in a fanned accretionary wedge in front of the subducting oceanic slab. A Late Eocene-Oligocene age is therefore likely for this early phase (Frizon de Lamotte et al., 2000, 2011; Marrone et al., 2020). The Filali thrust over the Beni Bousera carbonates would have occurred during this early phase of the Alpine orogeny. Furthermore, we suggest that the Filali Unit belongs to the middle crust previously detached from the lower crust during Triassic-Jurassic rifting and hyperextension of the margin. In other words, the FBBSZ formed from inversion of the postulated Triassic-Jurassic detachment.

The geodynamic interpretation of the Alpine events that affected the Beni Bousera and Filali units is beyond the scope of this work. Recently, Rossetti et al. (2020) showed that the compressional Alpine events resulted in the re-burial of the previously exhumed crustal envelope of the peridotites. During a later episode, the collapse of the Alboran Domain tectonic wedge and opening of the back-arc Alboran basin was triggered by the southwestward rollback of the oceanic slab during the Late Oligocene-Early Miocene (Fig. 2B, D; e.g., Van Hinsbergen et al., 2014; Gueydan et al., 2015; Homonnay et al., 2018). Extensional faulting strongly affected the Filali Unit at that time (El Bakili et al., 2020) and is also recorded in the BBMs (Fig. 7F).

\subsection{Early exhumation of subcontinental peridotites in the West Alpine-Pyrenees realm}

Several, and famous subcontinental peridotites are known in the Western Mediterranean belts and the Pyrenees. This section aims to compare the setting and exhumation history of these various occurrences with that described above for the Beni Bousera marbles.

\subsubsection{Betics}

The BBMs overlie the Beni Bousera mantle-granulite unit and underlie the Filali crustal unit. Two areas of the Ronda peridotite massif could be candidates for similar settings, i.e., the southern part of the massif (Estepona-Benahavis-Guadaiza area) and its frontal part at the contact with the Las Nieves carbonates (Fig. 16).

In the Estepona-Benahavis-Guadaiza region, Sanz de Galdeano and Ruiz-Cruz (2016) describe the transgression of a Permian-Triassic sequence onto the Ronda peridotites. The mantle rocks would be stratigraphically overlain by a magmatic, chaotic formation (including blocks of schists and peridotites), followed upward by a metadetrital series (again with schist and peridotite pebbles) passing progressively upward to marbles. A metarhyolite intercalated in the metadetrital series yields a U-Pb zircon age of $\sim 270 \mathrm{Ma}$, and the overlying marbles are assigned to the Triassic. The authors have observed that in some sectors these marbles overlie the peridotites directly. These conclusions are at odds with the current view that the Ronda peridotites were thrust over chaotic meta-magmatic formations and associated marbles of the so-called Guadaiza-Ojen nappe (e.g., Lundeen, 1978; Sánchez-Gómez et al., 1995; Esteban et al., 2008; AcostaVigil et al., 2014). However, the similarities with the setting of the BBMs are striking, except that no crustal unit comparable to the Filali Unit directly overlies the uppermost PermoTriassic series. The Jubrique unit overlies the Ronda peridotites $\sim 7-8 \mathrm{~km}$ further to the NW through a granuliticmigmatitic formation, similar to the Beni Bousera kinzigites (peak $P-T$ conditions of $12.5-13 \mathrm{kbar}, 780^{\circ} \mathrm{C}$, Balanyá et al., 1997; Massonne, 2014, or $12-14 \mathrm{kbar}, ~ 850^{\circ} \mathrm{C}$, Barich et al., 2014).

Another possible correlation concerns the north-western front of the Ronda peridotites of the Sierra Bermeja massif at their contact with the Nieves unit (Fig. 16). The latter is a $\sim 1500 \mathrm{~m}$ thick, near vertical or overturned series which, from SE to NW, consists of undated (Middle Triassic?) impure dolomitic marbles, Norian marbles and dolostones, Rhaetian marbles and calcschists, Lower Jurassic cherty limestones, and a Middle Jurassic-Paleogene condensed succession ending with a cellular dolomitic breccia (Mazzoli et al., 2013). The authors describe a strong metamorphic gradient in the Nieves formations: for a maximum pressure of $3 \mathrm{kbar}$, peak temperature $>510^{\circ} \mathrm{C}$ (probably $\sim 700^{\circ} \mathrm{C}$ ) in the forsterite zone adjacent to the peridotite; $510-430^{\circ} \mathrm{C}$ in a more distant, diopside-in zone; $430-360^{\circ} \mathrm{C}$ for the tremolite-in zone in the 


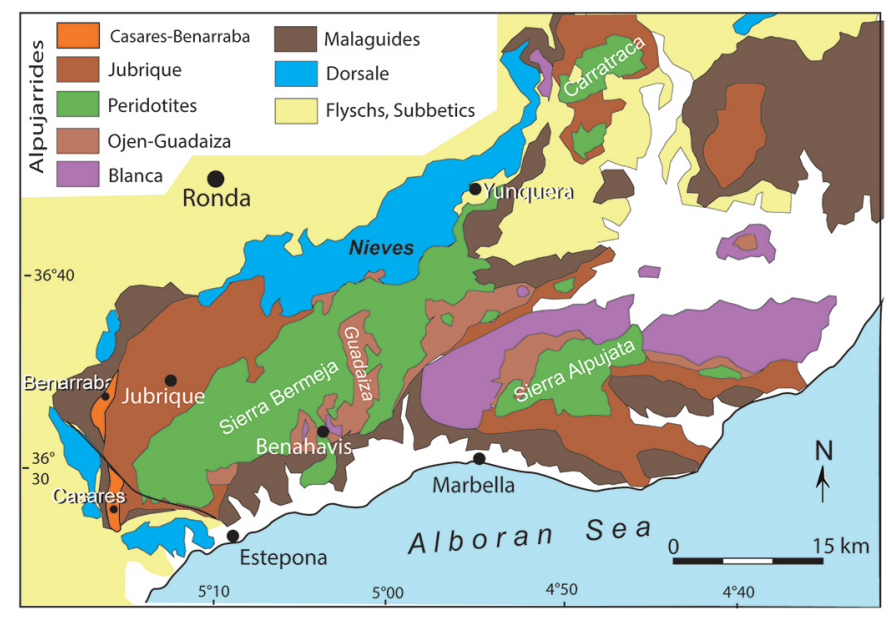

Fig. 16. Sketch map of the Western Betics (see Fig. 1 for location) simplified after Balanyá et al. (1997), Sanz de Galdeano et al. (1999) and Mazzoli et al. (2013). White fill: Pliocene-Quaternary deposits.

Norian dolomites and $360-330^{\circ} \mathrm{C}$ for the phlogopite-in zone. Mazzoli et al. (2013) ascribe this strong gradient to the Alpine thrust of the Ronda mantle wedge above the Alpujarride crustal domain and its Triassic-Paleogene succession. However, Bessière (2019) considers the relationship between the Ronda mantle rocks and the Nieves dolomitic marbles as an extensional contact related to the exhumation of the mantle in a hyperextended passive margin. The HT-LP metamorphism would have developed in an extensional setting under the shallow burial of the Nieves series due to a massive circulation of water next to the triple junction between the thinned crust (Jubrique unit), the mantle, and the overlying series. The authors do not firmly date this metamorphic event, but ${ }^{40} \mathrm{Ar} /{ }^{39} \mathrm{Ar}$ dating on phlogopite from the highest $T(>600$ $550^{\circ} \mathrm{C}$ ) zone along the peridotite massif yields ages of $\sim 20 \mathrm{Ma}$ (Bessière, 2019). The Nieves marbles overlie the peridotites as mostly do the BBMs, but they are not intercalated between the peridotites and the Jubrique crustal unit. To the NE, the Jubrique unit overlies and truncates the Nieves formations through a late, low-angle normal fault (Fig. 16), which according to Balanyá et al. (1997) and Sánchez-Gómez et al. (2002) continues beneath the peridotites. The long claimed correlation between the Filali and Jubrique units now seems controversial as the latter has kinzigites at its base (Barich et al., 2014), whereas the Filali gneisses are separated from the Beni Bousera kinzigites by the BBMs.

Marbles associated with gneiss also occur inside the Sierra Bermeja peridotite massif, but may be referred to tectonic slices of the underlying Blanca-Guadaiza unit (Sánchez-Gómez et al., 2002; Précigout et al., 2013). These marble-gneiss intercalations connect southward in the Estepona area with the outcrops described above (Sanz de Galdeano and Ruiz-Cruz, 2016). To summarize, based on the available literature, none of the potential correlations of the BBMs with similar marbles in contact with the Ronda peridotites can presently be used to corroborate or refute the notion of an early exhumation of the Beni Bousera peridotites as presented in this paper.

\subsubsection{Pyrenees}

The Pyrenees offer a remarkable example of an orogen with subcontinental mantle rocks (e.g., the famous lherzolites of Lherz) exhumed during the opening of an axial rift, which was later mildly inverted (Fig. 17). Nowadays, this rift and its paleomargins correspond to the North Pyrenean Fault (NPF) zone with its rosary of small lherzolite bodies and associated breccias (Jammes et al., 2009; Clerc and Lagabrielle, 2014; Clerc et al., 2015; Asti et al., 2019; Lagabrielle et al., 2019a, 2019b). The rifting event occurred during the late AptianTuronian, being connected to the opening of the Northern Atlantic through that of the Bay of Biscay (Fig. 1, insert; Fig. 17). In the Western Pyrenees (Mauléon Basin), according to Jammes et al. (2009), the Late Triassic to Jurassic pre-rift carbonate platform was stretched during the rifting stage, and detachment faults exhumed deep crustal and mantle rocks to the seafloor. The final basin structure is characterized by extensional allochthons that have glided on the Triassic evaporites from the proximal margin as to overlie the exhumed rocks of the distal margin. This complex architecture is overprinted by a magmatic/low-grade thermal event that postdates the mantle exhumation. In the same area, Lagabrielle et al. (2019a, 2019b) show that the serpentinized peridotites, which are topped by ophicalcites and partly covered by sedimentary breccias, were strongly metasomatized at $\sim 110 \mathrm{Ma}$ (Albian), contemporaneously with some alkaline volcanism.

The syn- to post-rift thermal anomaly is much more important in the Eastern Pyrenees, where HT-LP metamorphism at $\sim 550{ }^{\circ} \mathrm{C}, 3-4 \mathrm{kbar}$ is recorded in the Mesozoic series of the NPF zone (Clerc and Lagabrielle, 2014). These authors proposed a "hot hyperextended margin" model, within which the Triassic-Jurassic pre-rift sequence would have been recrystallized in situ at the contact of the ascending mantle rocks, beneath a blanket of Late Cretaceous flysch, whereas most of the Paleozoic crust would have been extracted laterally. Some slivers of granulitic gneisses are preserved, for instance in the Lherz - Port de Saleix area (Azambre and Ravier, 1978; Kornprobst and Vielzeuf, 1984; Clerc and Lagabrielle, 2014), which could record a first Paleozoic HT metamorphism event responsible for the granulitization, followed by a second HT metamorphism event during the Cretaceous (Clerc and Lagabrielle, 2015). High-T marbles are associated with the Port de Saleix granulites, which contain calcite, minor dolomite, forsterite, phlogopite, spinel and humites (Azambre and Ravier, 1978). They have been regarded as metasediments interbedded in the Pre-Variscan protoliths of the granulites but, like in the case of the Beni Bousera marbles, we may ask whether they are not remnants of a former Mesozoic cover of margin units.

\subsubsection{Maghrebides, Calabria, Alps and Corsica}

In the Edough massif $100 \mathrm{~km}$ east of Lesser Kabylia (Fig. 1, insert), which includes distinct outcrops of mantle material, the Bou Maiza succession comprises a lower unit with $50 \mathrm{~m}$-thick marbles associated with kyanite-staurolitegarnet metapelites, and an upper unit of marbles, phyllites and metagabbros (Bosch et al., 2014). The Bou Maiza metagabbros are interpreted as allochthonous oceanic fragments, whereas 


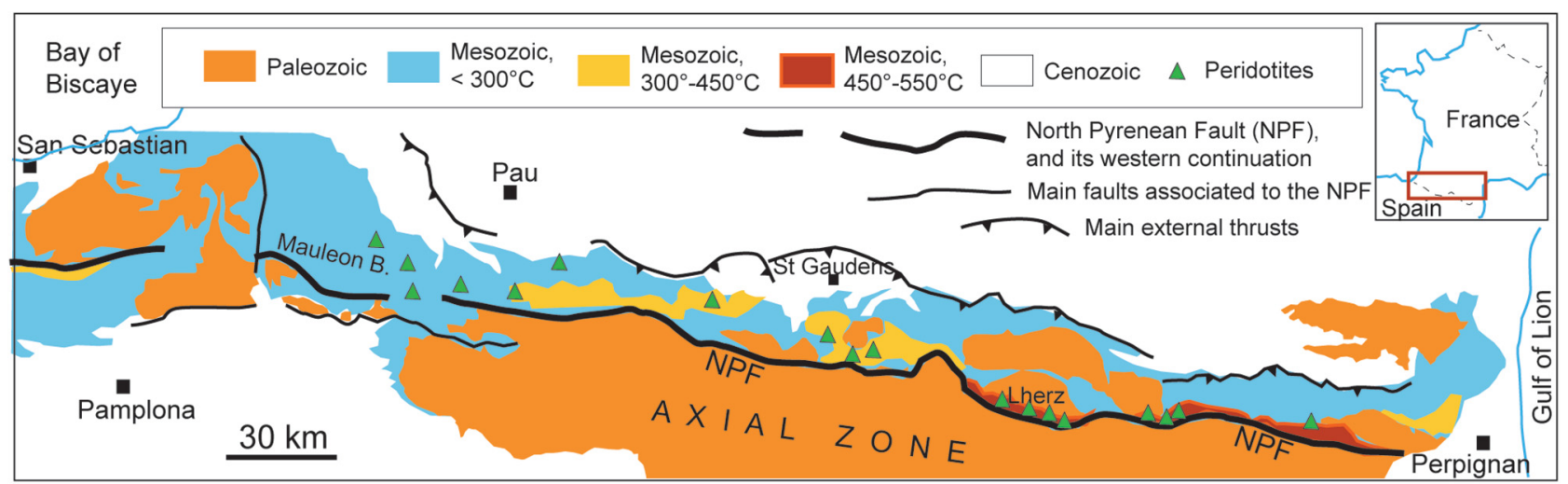

Fig. 17. Sketch map of the North Pyrenean Fault Zone, simplified after Clerc and Lagabrielle (2014).

the Sidi Mohamed peridotites are regarded as part of subcontinental lithospheric mantle incorporated into crustal units during the early stages of opening of the Algerian basin. Likewise, in the Lesser Kabylia itself, marbles are associated with the peridotites and kinzigites of Collo, which were compared by Bouillin (1978) to those of Beni Bousera (C. Chabou, personal comm.). To date the significance of these two marble occurrences has not been discussed.

In Calabria (Fig. 1, insert; Fig. 2B), the easternmost equivalent of the Alboran Domain is widely exposed in the Sila and Serre crustal massifs that overlie the ophiolitic Ligurian units (Rossetti et al., 2001; Vitale and Ciarcia, 2013). The sedimentary cover of the Sila massif is preserved and includes "Verrucano"-type deposits, overlain by carbonate TriassicSinemurian successions followed by Pliensbachian-Toarcian marly-olistolitic facies. The Middle Liassic extension is recorded by neptunian dykes that penetrate down to the Paleozoic basement (Bouillin and Bellomo, 1990). The Paleozoic massifs include a $\sim 7 \mathrm{~km}$-thick basal section which equilibrated in the medium-pressure granulite field (Schenk, 1984). Lenticular bodies of ultramafics are widespread in the lower part of the section. Siliceous marbles and calcsilicate rocks represent a minor proportion of these lower crustal rocks in the form of lenses ranging in thickness from a few centimeters to several tens of meters. These marbles are regarded as Paleozoic or older alike the host metapelites, whose HT-MP metamorphism is dated at $2295 \mathrm{Ma}$ (Schenk, 1980). Therefore, the Calabria marbles cannot be directly compared with the BBMs.

In the Western Alps (Fig. 18), peridotites associated with lower or middle continental crust units and pre- to syn-rift sediments are observed on both sides of the Piedmont-Ligurian oceanic suture zone. On the Adria side, the Baldissero and Finero peridotites appear at the base of the tilted Adria crust of the Ivrea Zone (Handy and Zingg, 1991; Schmid et al., 2017). Due to the movement along the shear zone (now vertical) which separates the lower crust from the upper crust, the thickness of the granulitic lower crust and underplated gabbros (Vavra et al., 1999) along strike varies from $10 \mathrm{~km}$ to less than $1 \mathrm{~km}$. The pre-rift to early syn-rift deposits range in age from the Late Carboniferous to the Upper Triassic. The more distal margin is (poorly) exposed in the narrow Canavese Zone,

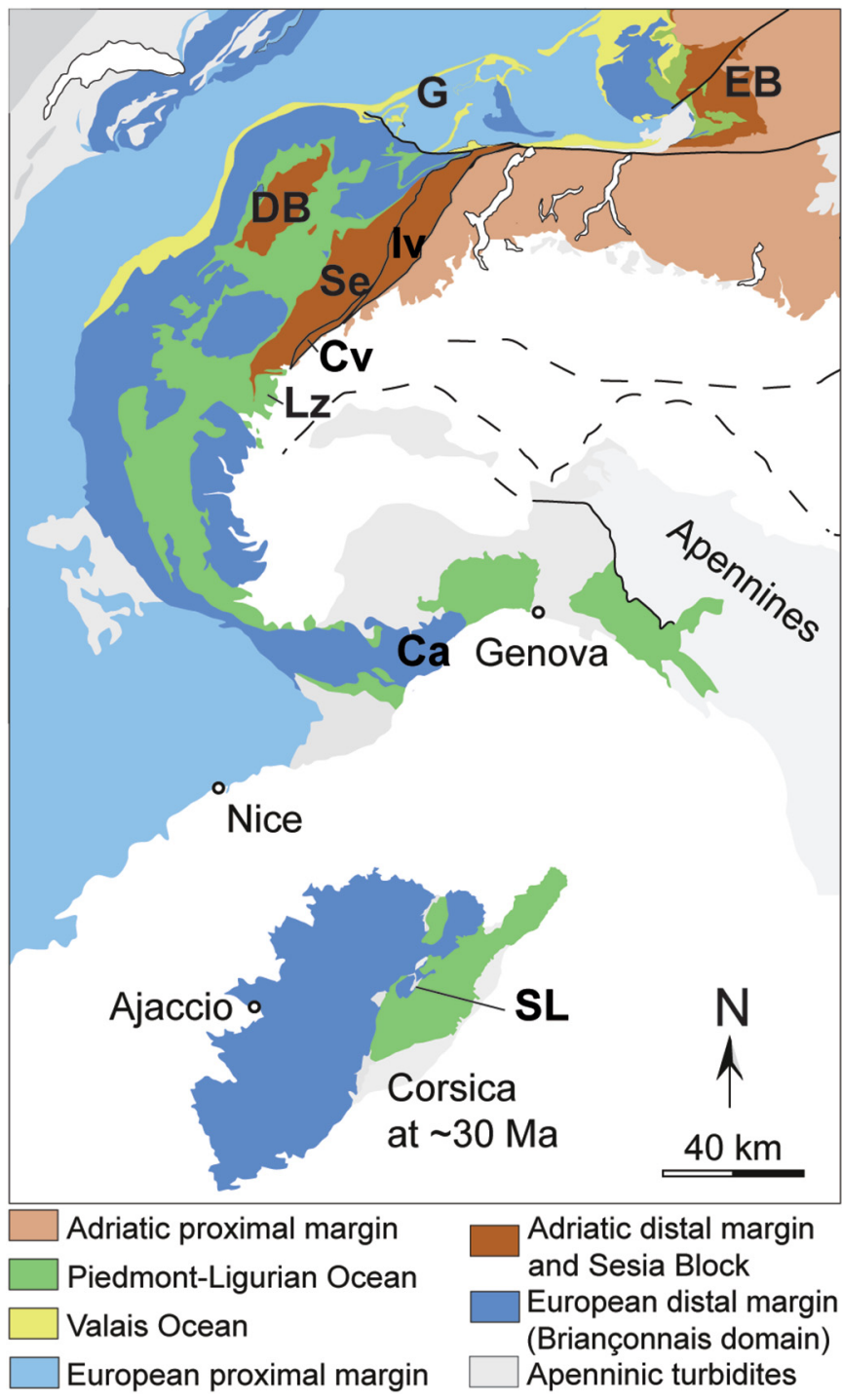

Fig. 18. Sketch map of the Western-Central Alps and Corsica, modified after Chenin et al. (2019). Ca, Calizzano; Cv, Canavese; DB, Dent Blanche; EB, Err-Bernina; G, Geisspfad; Iv, Ivrea; Lz, Lanzo; Se, Sesia; SL, Santa Lucia. 


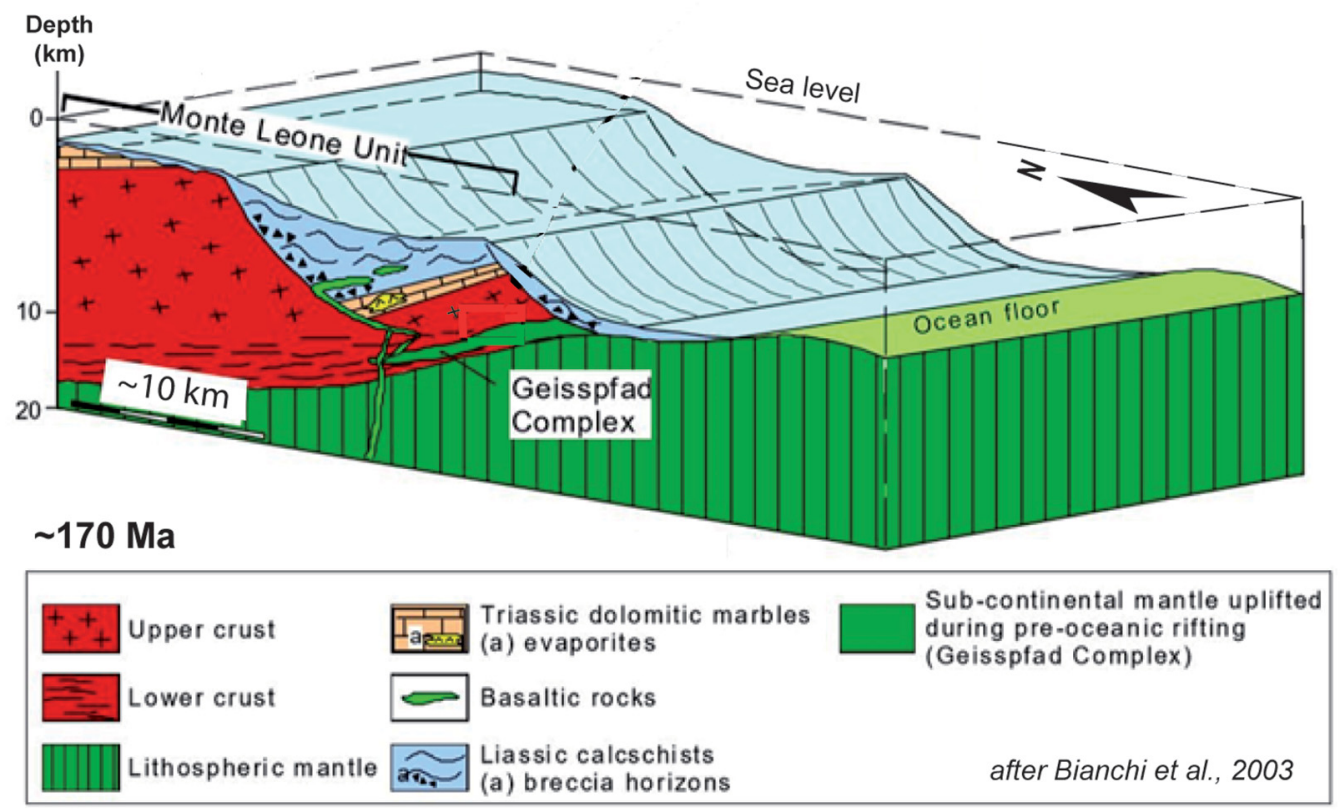

Fig. 19. Interpretation of the Geisspfad peridotite-gabbro-gneiss complex, after Bianchi et al., 2003. The natural cross-section is overturned (Monte Leone nappe). See location in Figure 16.

which bounds the Ivrea Zone to the WNW (Elter et al., 1966; Ferrando et al., 2004; Festa et al., 2020). Besides a serpentinized peridotite unit, the basement units comprise lower or upper crustal rocks overlain by pre- to early syn-rift (Late Carboniferous, Permian, Triassic), to syn-rift (LiassicMiddle Jurassic), to post-rift sediments (Late Jurassic-Early Cretaceous).

Due to the dramatic Adria-Europe collision associated with tilting and strong strike-slip movements (Schmid et al., 2017), the geometry of the Canavese distal margin units prior to the Alpine orogeny is controversial. The initial geometry of the hyperextended Adria margin is much better restored in the Err-Bernina transect of the Central Alps (Manatschal, 2004; Mohn et al., 2010; Incerpi et al., 2017; Chenin et al., 2019). There, the crust thins down to a few meters of breccia due to normal and low-angle detachment faults that root on top of the lithospheric mantle. Blocks and slabs, tilted to varying degrees, consisting of early syn-rift, mainly Triassic deposits, may constitute continental allochthons on the thinned crust or the exhumed mantle of the Ocean-Continent Transition.

Also in the Central Alps, but linked to the European margin, we find an example of subcontinental peridotites associated with gabbros, i.e., the Geisspfad peridotites (Pastorelli et al., 1995; Bianchi et al., 2003; Pelletier et al., 2008). These mantle rocks are exposed in the overturned Monte Leone nappe of the Simplon culmination (Fig. 18). When restored to their pre-orogenic position, these peridotites appear to be overlain by a thinned gneissic crust, which is covered by early syn-rift Triassic sediments and younger synrift breccias (Fig. 19). Thus, the restored Geisspfad setting is strongly suggestive of the possible Beni Bousera setting prior to Alpine events.

In Corsica (Fig. 18), the transition zone between the European margin and the Ligurian Tethys is exposed in the Santa Lucia nappe, which shows a $2-4 \mathrm{~km}$ thick layered
"Mafic Complex" whose base hosts slices of mantle rocks attaining a thickness up to $50 \mathrm{~m}$ (Rossi et al., 2006; Beltrando et al., 2013). U-Pb zircon and Sm-Nd analyses on meta-pelitic septa allowed Rossi et al. (2006) to date the magmatic intrusion under granulite-facies conditions $\left(\sim 7 \mathrm{kbar}, 800^{\circ} \mathrm{C}\right)$ at $\sim 280 \mathrm{Ma}$, and the onset of cooling at $195 \pm 9 \mathrm{Ma}$, respectively. The "Mafic Complex" is overlain by a "Diorite-Granite Complex", which is a shallower Permian complex separated from the HP-HT complex by a shear zone where ${ }^{40} \mathrm{Ar} /{ }^{39} \mathrm{Ar}$ dates reveal Triassic-Jurassic activity. Beltrando et al. (2013) conclude that the Permian lower crust was progressively exhumed to the sea floor, from the Middle Triassic to Middle Jurassic, along the footwall of a low-angle detachment fault typical of a hyperextended passive margin. To the north, the Corsican paleomargin correlates with the Calizzano massif of the Ligurian Briançonnais (Seymour et al., 2016; Decarlis et al., 2017).

\section{Conclusions}

The BBMs are exposed in small outcrops around the granulitic envelope (kinzigites) of the Beni Bousera subcontinental peridotites. Despite their modest extent, a study of these marbles leads to revisiting current models that interpret the exhumation of the Gibraltar Arc mantle rocks as a basically Cenozoic process.

The marbles are not intercalated in the kinzigites, but rather pinched within a mylonitic thrust contact between the kinzigites and the overlying Filali mid-crustal unit. The Filali-Beni Bousera Shear Zone (FBBSZ) can no longer be considered as extensional and equivalent to the deeper Kinzigites-Peridotites Shear zone (KPSZ). The protoliths of the most typical BBMs formed a series of sandy and sometimes pebbly carbonates, dolostones, and magnesian 
limestones locally interlayered with argillites. They are comparable to the Triassic series of the less recrystallized Alpujarrides-Sebtides units.

Zircons from the BBMs exhibit cores of detrital origin with rim overgrowths dated at $\sim 21 \mathrm{Ma}$. The youngest age cluster from the cores peaks at $\sim 270 \mathrm{Ma}$, which suggests the erosion of Middle Permian magmatic sources, and supports a Triassic age for the marble protoliths.

At this stage, we consider two alternative explanations for the presence of these marbles in the FBBSZ: either the likely Triassic beds were deposited unconformably onto the kinzigites, or they were emplaced as extensional allochthons above the detachment allowing the granulitic crust to be exhumed during latest Triassic-Early Jurassic time. In both cases, the Beni Bousera mantle rocks would have been exhumed to shallow depth during the early rifting events responsible for the birth of the Maghrebian Tethys.

The BBMs and their host rock units, i.e., the peridotites and associated thinned crustal units, are relics of the hyperextended southern margin of the Alboran Domain severely affected by re-burial, thrusting, and metamorphism during the Alpine orogeny before their final exhumation. Correlations with other subcontinental peridotite occurrences from the West AlpinePyrenees realm support this proposition: at most localities, early exhumation linked to the late Variscan collapse and subsequent continental rifting occurred before inversion and final exhumation.

\section{Supplementary Material}

Supplementary Figures S1 to S6 and Table S1.

The Supplementary Material is available at https://www.bsgf. fr/10.1051/bsgf/2021015/olm.

Acknowledgements. The authors greatly benefited from the friendly help of Prof. M. Ouazzani-Touhami at Tetouan. C.C. warmly thanks Kurt Bucher for his generous input on phase relations in dolomite marbles, and Damien Deldicque, ENS Paris, for help with the electron microscope. A.M. is indebted to Pauline Chenin for making available a figure, to Charaf Chabou for his comments, and to the Faculty of Sciences of Casablanca Aïn Chock for logistic support. We are greatly indebted to Yves Lagabrielle, Federico Rossetti and an anonymous reviewer for their very accurate, constructive and helpful reviews, to Barry Kohn for language editing and to Laurent Jolivet who encouraged us to revise our manuscript with an increased delay linked to the present pandemic.This is the IBERSIMS publication No. 79.

\section{References}

Acosta-Vigil A, Rubatto D, Bartoli O, Cesare B, Meli S, Pedrera A, et al. 2014. Age of anatexis in the crustal footwall of the Ronda peridotites, S Spain. Lithos 210-211: 147-167. https://doi.org/ 10.1016/j.lithos.2014.08.018.

Afiri A, Gueydan F, Pitra P, Essaifi A, Précigout J. 2011. OligoMiocene exhumation of the Beni-Bousera peridotite through a lithosphere-scale extensional shear zone. Geodinamica Acta 24: 49-60. https://doi.org/10.3166/ga.24.49-60.
Allmendinger RW, Cardozo NC, Fisher D. 2013, Structural Geology Algorithms: Vectors \& Tensors. Cambridge, England: Cambridge University Press, 289 p.

Álvarez-Valero AM, Jagoutz O, Stanley J, Manthei C, El Maz A, Moukadiri A, et al. 2014. Crustal attenuation as a tracer for the emplacement of the Beni Bousera ultramafic massif (Betico-Rifean belt). Geol Soc Am Bull 126: 1614-1624. https://doi.org/10.1130/ B31040.1.

Angrand P, Mouthereau F, Masini E, Asti R. 2020. A reconstruction of Iberia accounting for W-Tethys/N-Atlantic kinematics since the late Permian-Triassic. Solid Earth Discussions 1-24. https://doi. org/10.5194/se-2020-24.

Anovitz LM, Essene EJ. 1967. Phase equilibria in the system $\mathrm{CaCO}_{3}-$ $\mathrm{MgCO}_{3}-\mathrm{FeCO}_{3}$. Journal of Petrology 28: 389-414.

Arenas R, Sánchez Martínez S, Albert R, Haissen F, FernándezSuárez J, Pujol-Solà N, et al. 2020. 100 Ma cycles of oceanic lithosphere generation in peri-Gondwana: Neoproterozoic to Devonian ophiolites from the NW African-Iberian margin of Gondwana and the Variscan Orogen. Geol Soc Lond Spec Publ. https://doi.org/10.1144/SP503-2020-3.

Asti R, Lagabrielle Y, Fourcade S, Corre B, Monié P. 2019. How do continents deform during mantle exhumation? Insights from the northern Iberia inverted paleo-passive margin, western Pyrenees (France). Tectonics 38: 1666-1693. https://doi.org/10.1029/ $2018 \mathrm{TC} 005428$.

Augier R, Jolivet L, Robin C. 2005. Late Orogenic doming in the eastern Betic Cordilleras: Final exhumation of the NevadoFilabride complex and its relation to basin genesis. Tectonics 24: 1-19. https://doi.org/10.1029/2004TC001687.

Azambre B, Ravier J. 1978. Les écailles de gneiss du faciès granulite $\mathrm{du}$ Port de Saleix et de la région de Lherz (Ariège), nouveaux témoins du socle profond des Pyrénées. Bull Soc Géol Fr 20(3): 221-228.

Balanyá JC, García-Dueñas V, Azañón JM, Sánchez-Gómez M. 1997. Alternating contractional and extensional events in the Alpujarride nappes of the Alboran Domain (Betics, Gibraltar Arc). Tectonics 16: 226-238. https://doi.org/10.1029/96TC03871.

Balestro G, Festa A, Dilek Y. 2019. Structural architecture of the western alpine ophiolites, and the Jurassic seafloor spreading tectonics of the alpine Tethys. Journal of the Geological Society 176: 913-930. https://doi.org/10.1144/jgs2018-099.

Ballèvre M, Fourcade S, Capdevila R, Peucat JJ, Cocherie A, Fanning CM. 2012. Geochronology and geochemistry of Ordovician felsic volcanism in the Southern Armorican Massif (Variscan belt, France): implications for the breakup of Gondwana. Gondwana Res 21: 1019-1036.

Barich A, Acosta-Vigil A, Garrido CJ, Cesare B, Tajčmanová L, Bartoli O. 2014. Microstructures and petrology of melt inclusions in the anatectic sequence of Jubrique (Betic Cordillera, S Spain): implications for crustal anatexis. Lithos 206-207: 303-320.

Baudelot S, Bouhdadi S, Durand-Delga M. 1984. Datation palynologique du Trias moyen au sein des grès rouges « permotriasiques » des environs de Tétouan (Rif septentrional, Maroc). C R Acad Sci Paris 299: 1061-1068.

Bea F, Montero P, Talavera C, Abu Anbar M, Scarrow JA, Molina JF, et al. 2010. The palaeogeographic position of Central Iberia in Gondwana during the Ordovician: evidence from zircon chronology and Nd isotopes. Terra Nova 22: 341-346.

Beltrando M, Zibra I, Montanini A, Tribuzio R. 2013. Crustal thinning and exhumation along a fossil magma-poor distal margin preserved in Corsica: A hot rift to drift transition? Lithos 168-169: 99-112. https://doi.org/10.1016/j.lithos.2013.01.017. 
Benzaggagh M, Mokhtari A, Rossi P, Michard A, El Maz A, Chalouan A, et al. 2014. Oceanic units in the core of the External Rif (Morocco): Intramargin hiatus or South-Tethyan remnants? Journal of Geodynamics 77: 4-21. https://doi.org/10.1016/j. jog.2013.10.003.

Berman RG. 1988. Internally-consistent thermodynamic data for minerals in the system: $\mathrm{Na}_{2} \mathrm{O}-\mathrm{K}_{2} \mathrm{O}-\mathrm{CaO}-\mathrm{MgO}-\mathrm{FeO}-\mathrm{Fe}_{2} \mathrm{O}_{3}-$ $\mathrm{Al}_{2} \mathrm{O}_{3}-\mathrm{SiO}_{2}-\mathrm{TiO}_{2}-\mathrm{H}_{2} \mathrm{O}-\mathrm{CO}_{2}$. Journal of Petrology 29: 445-522.

Bessière E. 2019. Évolution géodynamique des Zones Internes des Cordillères Bétiques (Andalousie, Espagne) : Apports d'une étude pluridisciplinaire du Complexe Alpujárride. Orléans: Sci. Terre, Univ. https://tel.archives-ouvertes.fr/tel-02392008.

Bianchi GW, Pastorelli S, Martinotti G, Michard A, Piccardo G. 2003. Uplift of subcontinental lithospheric mantle during pre-oceanic rifting: The Geisspfad Complex, an example from the Western Alps. In: Third Intern. Coll. "3 Ma". Univ. Hassan II Casablanca, Abstr. vol. and Poster.

Bill M, O’Dogherty L, Guex J, Baumgartner PO, Masson H. 2001. Radiolarite ages in Alpine-Mediterranean ophiolites: Constraints on the oceanic spreading and the Tethys-Atlantic connection. Bulletin of the Geological Society of America 113: 129-143. https://doi.org/ 10.1130/0016-7606(2001)113<0129:RAIAMO > 2.0.CO;2.

Black LP, Kamo SL, Allen CM, Davis DW, Aleinikoff JN, Valley JW, et al. 2004. Improved ${ }^{206} \mathrm{~Pb} /{ }^{238} \mathrm{U}$ microprobe geochronology by the monitoring of a trace-element-related matrix effect; SHRIMP, IDTIMS, ELA-ICP-MS and oxygen isotope documentation for a series of zircon standards. Chem Geol 205: 115-140.

Bosch D, Hammor D, Mechati M, Fernandez L, Bruguier O, Caby R, et al. 2014. Geochemical study (major, trace elements and $\mathrm{Pb}-\mathrm{Sr}-$ $\mathrm{Nd}$ isotopes) of mantle material obducted onto the North African margin (Edough Massif, North Eastern Algeria): Tethys fragments or lost remnants of the Liguro-Provençal basin? Tectonophysics 626: 53-68. https://doi.org/10.1016/j.tecto.2014.03.031.

Bouillin JP. 1978. La transversale de Collo et d'El Milia (Petite Kabylie) : une région-clef pour l'interprétation de la tectonique alpine de la chaîne littorale d'Algérie. Mém Soc Géol Fr (n.s.) 57 (135): 84 p.

Bouillin JP. 1986. Le « bassin maghrébin » : une ancienne limite entre 1'Europe et l'Afrique à l'ouest des Alpes. Bull Soc Géol Fr 8(2): 547-558.

Bouillin JP, Bellomo D. 1990.Les filons sédimentaires jurassiques de Longobucco-Calaveto (Calabre, Italie); application à l'étude des paléostructures d'une marge téthysienne. Geodinamica Acta 4: 111-120. https://doi.org/10.1080/09853111.1990.11105203.

Bouillin JP, Durand-Delga M, Olivier P. 1986. Betic-Rifian and Tyrrhenian Arcs: distinctive features, genesis and development stages. In: Wezel JF, ed. The Origin of Arcs. Amsterdam: Elsevier Publ, pp. 281-304. https://doi.org/10.1016/B978-0-444-426888.50017-5.

Bouybaouene ML. 1993. Étude pétrologiques des métapélites des Sebtides supérieures, Rif interne, Maroc. PhD thesis. Rabat: Univ. Mohamed V, $160 \mathrm{p}$.

Bouybaouene ML, Goffé B, Michard A. 1995. High pressure, lowtemperature metamorphism in the Sebtides nappes, northern Rif, Morocco. Geogaceta 17: 117-119.

Bouybaouene ML, Goffé B, Michard A. 1998. High-pressure granulites on top of the Beni Bousera peridotites, Rif belt, Morocco: A record of an ancient thickened crust in the Alboran Domain. Bull Soc Géol Fr 169: 153-162.

Bradley DC, O'Sullivan P, Cosca MA, Motts HA, Horton JD, Taylor CD, et al. 2015. Synthesis of geological, structural, and geochronologic data (Phase V, Deliverable 53). In: Taylor CD, ed. Second Projet de Renforcement Institutionnel du Secteur Minier de la République
Islamique de Mauritanie (PRISM-II). U.S. Geological Survey Open-File Report 2013-12080-A, chapter A, pp. 328.

Brodie KH, Vavra Rex D, Rutter EH. 1989. On the age of deep crustal extensional faulting in the Ivrea Zone, northern Italy. InCoward MP, Dietrich D, Frank RG, eds.Alpine tectonics. Geol Soc Lond Spec Publ 45: 1-29.

Bucher K, Grapes R. 2011. Metamorphism of dolomites and limestones. Chapter 6 in Petrogenesis of Metamorphic Rocks, 8th ed. Berlin: Springer Verlag, pp. 225-255.

Cardozo N, Allmendinger RW. 2013. Spherical projections with OSXStereonet. Computers \& Geosciences 51: 193-205. https:// doi.org/10.1016/j.cageo.2012.07.021.

Castelli D, Rolfo F, Groppo C, Compagnoni R. 2007. Impure marbles from the UHP Brossasco-Isasca Unit (Dora-Maira Massif, western Alps): evidence for Alpine equilibration in the diamond stability field and evaluation of the $\mathrm{X}\left(\mathrm{CO}_{2}\right)$ fluid evolution. J Metamorphic Geol 25: 587-603.

Cattaneo G, Gélard JP, Aïte MO, Mouterde R. 1999. La marge septentrionale de la Téthys maghrébine au Jurassique (Djurdjura et Chellata, Grande Kabylie, Algérie). Bull Soc Géol Fr 170: 173-188.

Chalouan A, Michard A. 1990. The Ghomarides nappes, Rif coastal ranges, Morocco: A Variscan chip in the Alpine belt. Tectonics 9: 1565-1583. https://doi.org/10.1029/TC009i006p01565.

Chalouan A, Michard A. 2004. The Alpine Rif Belt (Morocco): a case of mountain building in a subduction-subduction-transform fault triple junction. Pure Appl Geophys 161: 489-519. https://doi.org/ 10.1007/s00024-003-2460-7.

Chalouan A, Michard A, El Kadiri KH, Negro F, Frizon de Lamotte D, Soto JI, et al. 2008. The Rif belt, in Continental Evolution: The Geology of Morocco; Structure, Stratigraphy and Tectonics of the Africa-Atlantic-Mediterranean Triple Junction, edited by Michard A, Saddiqi O, Chalouan A, Frizon de Lamotte D. Lect. Notes Earth Sci 116: 203-302.

Chenin P, Manatschal G, Decarlis A, Schmalholz SM, Duretz T, Beltrando M. 2019. Emersion of Distal Domains in Advanced Stages of Continental Rifting Explained by Asynchronous Crust and Mantle Necking. Geochemistry, Geophysics, Geosystems 20: 3821-3840. https://doi.org/10.1029/2019GC008357.

Chetouani K, Bodinier J-L, Garrido CJ, Marchesi C, Amri I, Targuisti K. 2016. Spatial variability of pyroxenite layers in the Beni Bousera orogenic peridotite (Morocco) and implications for their origin. C R Geosci 348: 619-629.

Chopin F, Corsini M, Schulmann K, El Houicha M, Ghienne J-F, Edel J-B. 2014.Tectonic evolution of the Rehamna metamorphic dome (Morocco) in the context of the Alleghanian-Variscan orogeny. Tectonics 33: 1154-1177. https://doi.org/10.1002/2014TC003539.

Claoué-Long JC, Compston W, Roberts J, Fanning CM. 1995. Two Carboniferous ages: a comparison of SHRIMP zircon dating with conventional zircon ages and ${ }^{40} \mathrm{Ar} /{ }^{39} \mathrm{Ar}$ analysis, in: Geochronology, Time Scales, and Global Stratigraphic Correlation. SEPM (Society for Sedimentary Geology) Spec Publ 4: 3-21.

Clerc C, Lagabrielle Y. 2014. Thermal control on the modes of crustal thinning leading to mantle exhumation: insights from the Cretaceous Pyrenean hot paleomargins. Tectonics 33: 1340-1359.

Clerc C, Lagabrielle Y. 2015. Reply to comment by P. Olivier on "Thermal control on the modes of crustal thinning leading to mantle exhumation: Insight from the Cretaceous Pyrenean hot paleomargins". Tectonics 34: 2275-2278. https://doi.org/10.1002/ 2015 TC003879.

Clerc C, Lahfid A, Monié P, Lagabrielle Y, Chopin C, Poujol M, et al. 2015. High-temperature metamorphism during extreme thinning of the continental crust: a reappraisal of the North Pyrenean passive 
paleo-margin. Solid Earth 6: 643-668. https://doi.org/10.5194/se6-643-2015.

Daudet M, Mouthereau F, Brichau S, Crespo-Blanc A, Gautheron C, Angrand P. 2020. Tectono-stratigraphic and thermal evolution of the western Betic flyschs: implications for the geodynamics of South Iberian margin and Alboran Domain. Tectonics 39. https:// doi.org/10.1029/2020TC006093.

Davies GR, Nixon PH, Pearson DG, Obata M. 1993. Tectonic implications of graphitized diamonds from the Ronda peridotite massif, southern Spain. Geology 21: 471-474. https://doi.org/ 10.1130/0091-7613(1993)021<0471:TIOGDF >2.3.CO;2.

de Capitani C, Petrakakis K. 2010. The computation of equilibrium assemblage diagrams with Theriak/Domino software. American Mineralogist 95: 1006-1016.

Decarlis A, Fellin MG, Maino M, Ferrando S, Manatschal G, Gaggero L, et al. 2017. Tectonothermal evolution of a distal rifted margin: Constraints from the Calizzano massif (Prepiedmont-Briançonnais domain, Ligurian Alps). Tectonics 36. https://doi.org/10.1002/ 2017 TC004634.

Dercourt J, Zonenshain LP, Ricou LE, et al. 1986. Présentation de 9 cartes paléogéographiques au 1/20.000.000 s'étendant de l'Atlantique au Pamir pour la période du Lias a l'Actuel. Bull Soc Géol Fr 8(1): 637-652.

Didon J, Durand Delga M, Kornprobst J. 1973. Homologies géologiques entre les deux rives du détroit de Gibraltar. Bull Soc Géol Fr 7(15): 77-105.

Díez-Fernández R, Arenas R, Pereira MF, Sanchez Martinez S, Albert R, Martin Parra L, et al. 2016. Tectonic evolutionof Variscan Iberia: Gondwana-Laurussia collision revisited. Earth Sci Rev 162: 269292.

Durand-Delga M, Kornprobst J. 1963. Esquisse géologique de la région de Ceuta (Maroc). C R Somm Séances Soc Géol Fr. https:// doi.org/10.2113/gssgfbull.S7-V.7.1049.

Durand-Delga M. 2006. Geological adventures and misadventures of the Gibraltar Arc. Z Deuts Gesel Geowiss 157: 687-716.

Durand-Delga M, Esteras Martín M, Olivier P. 2007. Los "Taríquides" (Arco de Gibraltar): Problemas estructurales, paleogeográficos y consideración histórica. Rev Soc Geol España 20: 119-134.

Ebert A, Herwegh M, Pfiffner A. 2007. Cooling induced strain localization in carbonate mylonites within a large-scale shear zone (Glarus thrust, Switzerland). Journal of Structural Geology 29: 1164-1184. https://doi.org/10.1016/j.jsg.2007.03.007.

El Atrassi F, Brunet F, Bouybaouene M, Chopin C, Chazot G. 2011. Melting textures and microdiamonds preserved in graphite pseudomorphs from the Beni Bousera peridotite massif, Morocco. European Journal of Mineralogy 23: 157-168. https://doi.org/ 10.1127/0935-1221/2011/0023-2094.

Elbaghdadi M, Tabit A, Kornprobst J, Duthou JL. 1996. Les injections acides dans le massif des Beni Bousera et son enveloppe métamorphique: conséquence sur l'évolution du métamorphisme et la cinématique. Notes et Mémoires du Service géologique du Maroc 387: 33-44.

El Bakili A, Corsini M, Chalouan A, Münch P, Romagny A, Lardeaux $\mathrm{JM}$, et al. 2020. Neogene polyphase deformation related to the Alboran basin evolution: new insights for the Beni Bousera massif (Internal Rif, Morocco). BSGF-Earth Sci Bull 191: 10. https://doi. org/10.1051/bsgf/2020008.

El Hadi H, Simancas JF, Tahiri A, González-Lodeiro F, Azor A, MartínezPoyatos D. 2006. Comparative review of the Variscan granitoids of Morocco and Iberia: Proposal of a broad zonation. Geodinamica Acta 19: 103-116. https://doi.org/10.3166/ga.19.103-116.
El Hatimi N, Duée G, Hervouët Y. 1991. La dorsale calcaire du Haouz: ancienne marge continentale passive téthysienne (Rif, Maroc). Bull Soc Géol Fr 162: 79-90.

ElKadiri KH,Linares A, OlorizF. 1992.LaDorsale calcaire rifaine(Maroc septentrional) : évolution stratigraphique et géodynamique durant le Jurassique-Crétacé. Notes Mém Serv Géol Maroc 336: 217-265.

El Kadiri KH. 2000-2002a. Jurassic ferruginous hardgrounds from the "Dorsale Calcaire" and the Jbel Moussa Group (internal Rif, Morocco) stratigraphical context and paleoceanographic consequences of mineralization processes. Geologica Romana 36: 33-70.

El Kadiri KH. 2000-2002b. "Tectono-Eustatic Sequences" of the Jurassic successions from the Dorsale Calcaire (internal Rif, Morocco): evidence from a eustatic and tectonic scenario. Geologica Romana 36: 71-104.

El Kadiri KH, Chalouan A, El Mrihi A, Hlila R, López-Garrido A, Sanz de Galdeano C, et al. 2001. Les formations sédimentaires de l'Oligocène supérieur-Miocène inférieur dans l'unité ghomaride des Beni-Hozmar (secteur de Talembote, Rif septentrional, Maroc). Eclogae Geol Helv 94: 313-320.

El Kadiri K, Hlila R, Sanz de Galdeano C, López-Garrido AC, Chalouan A, Serrano F, et al. 2006. Regional correlations across the Internides-Externides front (northwestern Rif Belt, Morocco) during the Late Cretaceous - Early Burdigalian times: Palaeogeographical and palaeotectonic implications. Geological Society Special Publication 262: 193-215. https://doi.org/10.1144/GSL. SP.2006.262.01.12.

El Kadiri KH, Horstemeyer MF, El Kadiri H, Pessagno EA. 2009. Jurassic radiolarite pulses from the Dorsale Calcaire (internal Rif, Morocco): A clue for correlating and interpreting the Tethyan radiolarites. Stratigraphy 6: 277-312.

Ellis DE. 1978. Stability and phase equilibria of chloride and carbonate bearing scapolites at $750{ }^{\circ} \mathrm{C}$ and 4000 bar. Geochimica Cosmochimica Acta 42: 1271-1281.

El Maz A, Guiraud F. 2001. Example of low-variance parageneses in the metapelite of Filali (inner Rif, Morocco): Description, interpretation and geodynamic implication. Bull Soc Géol Fr 172: 469-485. https://doi.org/10.2113/172.4.469.

Elter G, Elter P, Sturani C, Weidmann M. 1966. Sur la prolongation du domaine ligure de l'Apennin dans le Monferrat et les Alpes et sur l'origine de la Nappe de la Simme s.l. des Préalpes romandes et chablaisiennes. Archives Sci (Genève) 19: 279-377.

Esteban JJ, Cuevas J, Vegas N, Tubía JM. 2008. Deformation and kinematics in a melt-bearing shear zone from the Western Betic Cordilleras (Southern Spain). Journal of Structural Geology 30: 380-393. https://doi.org/10.1016/j.jsg.2007.11.010.

Favre P. 1992. Géologie des massifs calcaires situés au front sud de l'unité de Kétama (Rif, Maroc). Publ Départ Géol Paléont Univ Genève 11-138.

Ferrando S, Bernoulli D, Compagnoni R. 2004. The Canavese zone (internal Western Alps): A distal margin of Adria. Schweizerische Mineralogische und Petrographische Mitteilungen 84: 237-256.

Ferry JM. 1996. Three novel isograds in metamorphosed siliceous dolomites from the Ballachulish aureole, Scotland. American Mineralogist 81: 485-494.

Ferry JM. 2001. Calcite inclusions in forsterite. American Mineralogist 86: 773-779.

Ferry JM, Newton RC, Manning CE. 2002. Experimental determination of the equilibria: rutile + magnesite $=$ geikielite $+\mathrm{CO}_{2}$ and zircon +2 magnesite $=$ baddeleyite + forsterite $+2 \mathrm{CO}_{2}$. American Mineralogist 87: 1342-1350.

Festa A, Balestro G, Borghi A, De Caroli S, Succo A. 2020. The role of structural inheritance in continental break-up and exhumation of 
Alpine Tethyan mantle (Canavese Zone, Western Alps). Geoscience Frontiers 11: 167-188. https://doi.org/10.1016/j.gsf.2018.11.007.

Frets EC, Tommasi A, Garrido CJ, Vauchez A, Mainprice D, Targuisti $\mathrm{K}$, et al. 2014. The Beni Bousera Peridotite (Rif Belt, Morocco): an oblique-slip low-angle shear zone thinning the subcontinental mantle lithosphere. J Petrol 55: 283-313.

Frizon de Lamotte D, Saint Bezar B, Bracene R. 2000. The two main steps of the Atlas building and geodynamics of the western Mediterranean. Tectonics 19: 740-761. https://doi.org/10.1029/ 2000 TC900003.

Frizon de Lamotte D, Raulin C, Mouchot N, Wrobel-Daveau J-C, Blanpied C, Ringenbach JC. 2011. The southernmost margin of the Tethys realm during the Mesozoic and Cenozoic: Initial geometry and timing of the inversion processes. Tectonics 30: TC3002. https://doi.org/10.1029/2010TC002691.

Galindo-Zaldivar J, Braga JC, et al. 2019. Extension in the Western Mediterranean. In: Quesada C, Oliveira JT, eds. The Geology of Iberia: A Geodynamic Approach. Springer Nature, pp. 61-103.

García-Arias M, Díez-Montes A, Villaseca C, Blanco-Quintero IF. 2018. The Cambro-Ordovician Ollo de Sapo magmatism in the Iberian Massif and its Variscan evolution: A review. Earth-Science Reviews 176: 345-372. https://doi.org/10.1016/j.ear scirev.2017.11.004.

Garrido CJ, Gueydan F, Booth-Rea G, Precigout J, Hidas K, PadrónNavarta JA, et al. 2011. Garnet lherzolite and garnet-spinel mylonite in the Ronda peridotite: Vestiges of Oligocene backarc mantle lithospheric extension in the western Mediterranean. Geology 39: 927-930. https://doi.org/10.1130/G31760.1.

Gervilla F, González-Jiménez JM, Hidas K, Marchesi C, Piña R. 2019. Geology and metallogeny of the upper mantle rocks from the Serranía de Ronda. Soc Esp Miner Granada Univ: 122 p.

Gimeno-Vives O, Mohn G, Bosse V, Haissen F, Zaghloul MN, Atouabat A, et al. 2019. The Mesozoic margin of the Maghrebian Tethys in the Rif belt (Morocco): Evidence for polyphase rifting and related magmatic activity. Tectonics 38. https://doi.org/ 10.1029/2019TC005508.

Guerrera F, Martin-Algarra A, Perrone V. 1993. Late OligoceneMiocene syn-/-late-orogenic successions in Western and Central Mediterranean Chains from the Betic Cordillera to the Southern Apennines. Terra Nova 5: 525-544. https://doi.org/10.1111/ j.1365-3121.1993.tb00302.x.

Guerrera F, Martín-Martín M, Tramontana M. 2019. Evolutionary geological models of the central-western peri-Mediterranean chains: a review. International Geology Review 00: 1-22. https://doi.org/10.1080/00206814.2019.1706056.

Gueydan F, Mazzotti S, Tiberi C, Cavin R, Villaseñor A. 2019. Western Mediterranean Subcontinental Mantle Emplacement by Continental Margin Obduction. Tectonics 38: 2142-2157. https:// doi.org/10.1029/2018TC005058.

Gueydan F, Pitra P, Afiri A, Poujol M, Essaifi A, Paquette JL. 2015. Oligo-Miocene thinning of the Beni Bousera peridotites and their Variscan crustal host rocks, Internal Rif, Morocco. Tectonics 34: 1244-1268. https://doi.org/10.1002/2014TC003769.

Gysi AP, Jagoutz O, Schmidt M, Targuisti K. 2011. Petrogenesis of pyroxenites and melt infiltrations in the ultramafic complex of Beni Bousera, northern Morocco. Journal of Petrology 52: 1679-1735. https://doi.org/10.1093/petrology/egr026.

Haissen F, Garcia-Casco A, Torres-Roldan R, Aghzer A. 2004. Decompression reactions and $\mathrm{P}-\mathrm{T}$ conditions in high-pressure granulites from Casares-Los Reales units of the Betic-Rif belt (S Spain and N Morocco). Journal of African Earth Sciences 39: 375-383. https://doi.org/10.1016/j.jafrearsci.2004.07.030.
Handy MR, Zingg A. 1991. The tectonic and rheological evolution of an attenuated cross section of the continental crust: Ivrea crustal section, southern Alps, northwestern Italy and southern Switzerland. Geological Society of America Bulletin 103: 236253. https://doi.org/10.1130/0016-7606(1991)103<0236: TTAREO $>2.3 . \mathrm{CO} ; 2$.

Handy MR, Schmid SM, Bousquet R, Kissling E, Bernoulli D. 2010. Reconciling plate-tectonic reconstructions of Alpine Tethys with the geological-geophysical record of spreading and subduction in the Alps. Earth-Science Reviews 102: 121-158. https://doi.org/ 10.1016/j.earscirev.2010.06.002.

Handy MR, Ustaszewski K, Kissling E. 2015. Reconstructing the Alps-Carpathians-Dinarides as a key to understanding switches in subduction polarity, slab gaps and surface motion. International Journal of Earth Sciences 104: 1-26. https://doi.org/10.1007/ s00531-014-1060-3.

Hidas K, Varas-Reus MI, Garrido CJ, Marchesi C, Acosta-Vigil A, Padrón-Navarta JA, et al. 2015. Hyperextension of continental to oceanic-like lithosphere: The record of late gabbros in the shallow subcontinental lithospheric mantle of the westernmost Mediterranean. Tectonophysics 650: 65-79. https://doi.org/10.1016/j. tecto.2015.03.011.

Homonnay E, Corsini M, Lardeaux JM, Romagny A, Münch P, Bosch $\mathrm{D}$, et al. 2018. Miocene crustal extension following thrust tectonic in the Lower Sebtides units (internal Rif, Ceuta Peninsula, Spain): Implication for the geodynamic evolution of the Alboran Domain. Tectonophysics 722: 507-535. https://doi.org/10.1016/j. tecto.2017.11.028.

Ikenne M, Souhassou M, Arai S, Soulaimani A. 2017. A historical overview of Moroccan magmatic events along northwest edge of the West African Craton. J Afr Earth Sci 127: 3-15.

Incerpi N, Martire L, Manatschal G, Bernasconi SM. 2017. Evidence of hydrothermal fluid flow in a hyperextended rifted margin: the case study of the Err nappe (SE Switzerland). Swiss Journal of Geosciences 110: 439-456. https://doi.org/10.1007/s00015-0160235-2.

Jabaloy Sánchez A, Martín-Algarra A, Padrón-Navarta JA, MartínMartín M, Gómez-Pugnaire MT, López Sánchez-Vizcaíno V, et al. 2019a. Lithological Successions of the Internal Zones and Flysch Trough Units of the Betic Chain. In: Quesada C, Oliveira JT, eds. The Geology of Iberia: A Geodynamic Approach. Springer Nature ed., pp. 377-432. https://doi.org/10.1007/978-3-030-11295$0 \_8$.

Jabaloy Sánchez A, Padrón-Navarta JA, Gómez-Pugnaire MT, López Sánchez-Vizcaíno V, Garrido CJ. 2019b. Alpine Orogeny: Deformation and Structure in the Southern Iberian Margin (Beticss.1.). In: Quesada C, Oliveira JT, eds. The Geology of Iberia: A Geodynamic Approach. Springer Nature ed., pp. 453486. https://doi.org/10.1007/978-3-030-11295-0_10.

Jammes S, Manatschal G, Lavier L, Masini E. 2009. Tectonosedimentary evolution related to extreme crustal thinning ahead of a propagating ocean: Example of the western Pyrenees. Tectonics 28: TC4012. https://doi.org/10.1029/2008TC002406.

Janots E, Negro F, Brunet F, Goffé B, Engi M, Bouybaouène ML. 2006. Evolution of the REE mineralogy in HP-LT metapelites of the Sebtide complex, Rif, Morocco: Monazite stability and geochronology. Lithos 87: 214-234. https://doi.org/10.1016/j.lithos.2005.06.008.

Jolivet L, Faccenna C, Piromallo C. 2009. From mantle to crust: Stretching the Mediterranean. Earth and Planetary Science Letters 285: 198-209. https://doi.org/10.1016/j.epsl.2009.06.017.

Kornprobst J. 1974. Contribution à l'étude pétrographique et structurale de la Zone interne du Rif (Maroc septentrional). Notes Mém Serv Géol Maroc 251: 1-256. 
Kornprobst J, Vielzeuf D. 1984. Transcurrent crustal thinning: a mechanism for the uplift of deep continental crust/upper mantle associations. Kimberlites II: The Mantle and Crust-Mantle Relationships (Developments in Petrology, Volume 11B). Amsterdam: Elsevier, pp. 347-359. https://doi.org/10.1016/b978-0444-42274-3.50035-4.

Labails C, Olivet JL, Aslanian D, Roest WR. 2010. An alternative early opening scenario for the Central Atlantic Ocean. Earth and Planetary Science Letters 297: 355-368. https://doi.org/10.1016/j. epsl.2010.06.024.

Lafosse M, D'Acremont E, Rabaute A, et al. 2019. Plio-Quaternary tectonic evolution of the southern margin of the Alboran Basin (Western Mediterranean). Solid Earth Discussions 1-39. https:// doi.org/10.5194/se-2019-122.

Lagabrielle Y, Asti R, Fourcade S, Corre B, Poujol M, Uzel J, et al. 2019a. Mantle exhumation at magma-poor passive continental margins. Part I. 3D architecture and metasomatic evolution of a fossil exhumed mantle domain (Urdach lherzolite, northwestern Pyrenees, France). BSGF - Earth Sciences Bulletin 190: 8. https:// doi.org/10.1051/bsgf/2019007.

Lagabrielle Y, Asti R, Fourcade S, Corre B, Poujol M, Uzel J, et al. 2019b. Mantle exhumation at magma-poor passive continental margins. Part II. Tectonic and metasomatic evolution of largedisplacement detachment faults preserved in a fossil distal margin domain (Saraillé lherzolites, northwestern Pyrenees, France). https://doi.org/10.1051/bsgf/2019013.

Leprêtre R, De Lamotte DF, Combier V, Gimeno-Vives O, Mohn G, Eschard R. 2018. The Tell-Rif orogenic system (Morocco, Algeria, Tunisia) and the structural heritage of the southern Tethys margin. BSGF - Earth Sciences Bulletin 189. https://doi.org/10.1051/bsgf/ 2018009.

Li B, Massonne HJ. 2018. Two Tertiary metamorphic events recognized in high-pressure metapelites of the Nevado-Filábride Complex (Betic Cordillera, S Spain). J Metam Geol 36: 603-630.

Liati A. 1988. Corundum- and zoisite-bearing marbles in the Rhodope Zone, Xanthi area (N. Greece): Estimation of the fluid phase composition. Mineralogy and Petrology 38: 53-60.

Lonergan L, White N. 1997. Origin of the Betic-Rif mountain belt. Tectonics 16: 504-522. https://doi.org/10.1029/96TC03937.

Loomis TH. 1972. Diapiric emplacement of the Ronda hightemperature ultramafic intrusion, southern Spain. Geol Soc Am Bull 83: 2475-2496. https://doi.org/10.1130/0016-7606(1972)83[2475: DEOTRH]2.0.CO;2.

Lundeen MT. 1978. Emplacement of the Ronda peridotite, Sierra Bermeja, Spain. Geological Society of America Bull 89: 172-180. https://doi.org/10.1130/0016-7606(1978)89<172:EOTRPS >2.0. $\mathrm{CO} ; 2$.

Manatschal G. 2004. New models for evolution of magma-poor rifted margins based on a review of data and concepts from West Iberia and the Alps. International Journal of Earth Sciences 93: 432-466. https://doi.org/10.1007/s00531-004-0394-7.

Marrone S, Monié P, Rossetti F, Lucci F, Theye T, Bouybaouene ML, Zaghloul MN. 2020. The Pressure-Temperature-time-deformation history of the Beni Mzala unit (Upper Sebtides, Rif belt, Morocco): Refining the Alpine tectono-metamorphic evolution of the Alboran Domain of the Western Mediterranean. J Metam Geol. https://doi. org/10.1111/jmg. 12587.

Martín-Martín M, Martín-Rojas I, Caracuel JE, Estévez-Rubio A, Algarra AM, Sandoval J. 2006. Tectonic framework and extensional pattern of the Malaguide Complex from Sierra Espuña (Internal Betic Zone) during Jurassic - Cretaceous: Implications for the Westernmost Tethys geodynamic evolution. International
Journal of Earth Sciences 95: 815-826. https://doi.org/10.1007/ s00531-005-0061-7.

Martin-Rojas I, Somma R, Delgado F, Estévez A, Iannace A, Perrone $\mathrm{V}$, et al. 2009. Triassic continental rifting of Pangaea: Direct evidence from the Alpujarride carbonates, Betic Cordillera, SE Spain. Journal of the Geological Society 166: 447-458. https://doi. org/10.1144/0016-76492008-091.

Martin-Rojas I, Somma R, Delgado F, Estévez A, Iannace A, Zamparelli V. 2012. The Triassic platform of the Gador-Turon unit (Alpujarride complex, Betic Cordillera, southeast Spain): Climate versus tectonic factors controlling platform architecture. Facies 58 297-323. https://doi.org/10.1007/s10347-011-0275-z.

Massonne H-J. 2014. Wealth of P-T-t information in medium-high grade metapelites: Example from the Jubrique Unit of the Betic Cordillera, S Spain. Lithos 208-209: 137-157. https://doi.org/ 10.1016/j.lithos.2014.08.027.

Mazzoli S, Martín Algarra A. 2011. Deformation partitioning during transpressional emplacement of a "mantle extrusion wedge": The Ronda peridotites, Western Betic Cordillera, Spain. Journal of the Geological Society 168: 373-382. https://doi.org/10.1144/ 0016-76492010-126.

Mazzoli S, Martín-Algarra A, Reddy SM, Sánchez-Vizcaíno VL, Fedele L, Noviello A. 2013. The evolution of the footwall to the Ronda subcontinental mantle peridotites: Insights from the Nieves unit (western Betic Cordillera). Journal of the Geological Society 170: 385-402. https://doi.org/10.1144/jgs2012-105.

Melchiorre M, Álvarez-Valero AM, Vergés J, Fernàndez $M$, Belousova EA, El Maz A, et al. 2017. In situ U-Pb zircon geochronology on metapelitic granulites of Beni Bousera (BeticRif system, N Morocco). In: Bianchini G, Bodinier JL, Braga R, Wilson M, eds. The Crust-Mantle and Lithosphere-Asthenosphere Boundaries: Insights from Xenoliths, Orogenic Deep Sections, and Geophysical Studies. Geol Soc Am Spec Pap 526: 151-171.

Michard A, Goffé B, Chalouan A, Saddiqi O. 1991. Les corrélations entre les chaînes bético-rifaines et les Alpes et leurs conséquences. Bull Soc Géol Fr 162: 1151-1160.

Michard A, Goffé B, Bouybaouene ML, Saddiqi O. 1997. Late Hercynian-Mesozoic thinning in the Alboran Domain: Metamorphic data from the northern Rif, Morocco. Terra Nova 9: 171-174. https://doi.org/10.1046/j.1365-3121.1997.d01-24.x.

Michard A, Chalouan A, Feinberg H, Goffé B, Montigny R. 2002. How does the Alpine belt end between Spain and Morocco? Bulletin de la Société Géologique de France 173: 3-15. https://doi. org/10.2113/173.1.3.

Michard A, Negro F, Saddiqi O, Bouybaouene ML, Chalouan A, Montigny R, et al. 2006. Pressure-temperature-time constraints on the Maghrebide mountain building: Evidence from the Rif-Betic transect (Morocco, Spain), Algerian correlations, and geodynamic implications. Comptes Rendus Geoscience 338: 92-114. https:// doi.org/10.1016/j.crte.2005.11.011.

Michard A, Frizon de Lamotte D, Negro F. 2007. Serpentinite slivers and metamorphism in the External Maghrebides: Arguments for an intra-continental suture in the African paleomargin (Morocco, Algeria). Revista de la Sociedad Geológica de España 20: 173-185.

Michard A, Soulaimani A, Hoepffner C, Ouanaimi H, Baidder L, Rjimati EC, et al. 2010. The South-Western Branch of the Variscan Belt: Evidence from Morocco. Tectonophysics 492: 1-24.

Michard A, Mokhtari A, Chalouan A, Saddiqi O, Rossi P, Rjimati EC. 2014. New ophiolite slivers in the External Rif belt, and tentative restoration of a dual Tethyan suture in the western Maghrebides. Bulletin de la Société Géologique de France 185: 313-328. https:// doi.org/10.2113/gssgfbull.185.5.313. 
Michard A, Saddiqi O, Chalouan A, Farah A. 2020a. Early exhumation of the Beni Bousera peridotite-granulite unit (Internal Rif, Morocco) inferred from its metasedimentary cap; a new view on some marbles and regional implications. In: Proceedings $2 \mathrm{~d}$ Intern. Congr. Arab. J. Geosci. (CAJG 2), Sousse, Nov. 2019, Vol. 2, Sub-sect. 4.2, chapt. 125.

Michard A, Saddiqi O, Chalouan A, Chabou MC, Lach P, Rossi P, et al. 2020b. Comment on "The Mesozoic Margin of the Maghrebian Tethys in the Rif Belt (Morocco): Evidence for Polyphase Rifting and Related Magmatic Activity" by GimenoVives, et al. Tectonics 38. https://doi.org/10.1029/2019TC006004.

Michard A, Chalouan A, Farah A, Saddiqi O. 2021. The westernmost Tethyan margins in the Rif Belt (Morocco), a review. In: Khomsi S, Roure F, eds. Geology of North Africa and Mediterranean regions: sedimentary basins and Georesources. Springer Nature, in press.

Mohn G, Manatschal G, Müntener O, Beltrando M, Masini E. 2010. Unravelling the interaction between tectonic and sedimentary processes during lithospheric thinning in the Alpine Tethys margins. International Journal of Earth Sciences 99: 75-101. https://doi.org/10.1007/s00531-010-0566-6.

Molli G. 2008. Northern Apennine-Corsica orogenic system: an updated overview. In: Siegesmund, S, Fugenschuh B, Froitzheim $\mathrm{N}$, eds. Tectonic Aspects of the Alpine-Dinaride-Carpathian System. Geological Society Special Publication 298: 413-442. https://doi.org/10.1144/SP298.19.

Montel JM, Kornprobst J, Vielzeuf D. 2000.Preservation of old U-Th$\mathrm{Pb}$ ages in shielded monazite: example from the Beni Bousera Hercynian kinzigites (Morocco). J Metamorph Geol 18: 335-342.

Najih A, Montero P, Verati C, et al. 2019. Initial Pangean rifting north of the West African Craton: Insights from late Permian U-Pb and ${ }^{40} \mathrm{Ar} /{ }^{39} \mathrm{Ar}$ dating of alkaline magmatism from the Eastern AntiAtlas (Morocco). Journal of Geodynamics 132: 101670. https:// doi.org/10.1016/j.jog.2019.101670.

Negro F, Beyssac O, Goffé B, Saddiqi O, Bouybaouène ML. 2006. Thermal structure of the Alboran Domain in the Rif (northern Morocco) and the Western Betics (southern Spain). Constraints from Raman Spectroscopy of Carbonaceous Material. Journal of Metamorphic Geology 24: 309-327. https://doi.org/10.1111/ j.1525-1314.2006.00639.x.

Nold M, Uttinger J, Wildi W. 1981. Géologie de la Dorsale calcaire entre Tétouan et Assifane (Rif interne, Maroc). Notes Mém Serv Géol Maroc 300: 1-233.

Obata M. 1980. The Ronda peridotite-Garnet lherzolite, spinellherzolite, and plagioclase lherzolite facies and the P-T trajectories of a high-temperature mantle intrusion. J Petrol 21: 533-572.

Olivier P, Durand-Delga M, Manivit H, Feinberg H, Peybernès B. 1996. Le substratum jurassique des flyschs maurétaniens de l'ouest des Maghrébides: l'unité de Ouareg (région de Targuist, Rif, Maroc). Bull Soc Géol Fr 167: 609-616.

Olivier P. 1990. Les unités de Beni Derkoul (Rif, Maroc). Place et signification dans l'évolution alpine de la marge nord de la Téthys maghrébine. Bull Soc Géol Fr 8(6): 145-154. https://doi.org/ 10.2113/gssgfbull.VI.1.145.

Pastorelli S, Martinotti G, Piccardo GB, Rampone E, Scambelluri M. 1995. The Geisspfad Complex and its relationships with the Monte Leone Nappe (Lower Pennine, Western Alps). In: Polino R, Sacchi $\mathrm{R}$, eds. Atti del Convegno Rapporti Alpi-Appennino 1994. Rend Accad Naz Scienze Scritti e Documenti 14: 349-358.

Pearson DG, Nowell GM. 2004. Re-Os and Lu-Hf Isotope Constraints on the Origin and Age of Pyroxenites from the Beni Bousera Peridotite Massif: Implications for Mixed Peridotite-Pyroxenite Mantle Sources. J Petrol 45: 439-455. https://doi.org/10.1093/ petrology/egg102.
Pedrera A, Ruiz-Constán A, García-Senz J, Azor A, Marín-Lechado C, Ayala C, et al. 2020. Evolution of the South-Iberian paleomargin: From hyperextension to continental subduction. $J$ Struct Geol 138. https://doi.org/10.1016/j.jsg.2020.104122.

Pelletier L, Müntener O, Kalt A, Vennemann T, Belgya T. 2008. Emplacement of ultramafic rocks into the continental crust monitored by light and other trace elements: An example from the Geisspfad body (Swiss-Italian Alps). Chemical Geology 255: 143-159. https://doi.org/10.1016/j.chemgeo.2008.06.024.

Péron-Pinvidic G, Manatschal G. 2009. The final rifting evolution at deep magma-poor passive margins from Iberia-Newfoundland: A new point of view. International Journal of Earth Sciences 98: 1581-1597. https://doi.org/10.1007/s00531-008-0337-9.

Perrone V, Martin-Algarra A, Critelli S, et al. 2006. "Verrucano" and "Pseudoverrucano" in the Central-Western Mediterranean Alpine Chains: palaeogeographical evolution and geodynamic significance. In: Moratti G, Chalouan A, eds. Tectonics of the Western Mediterranean and North Africa. Geol Soc Lond Spec Publ 262: 143. https://doi.org/10.1144/GSL.SP.2006.262.01.01.

Platt JP, Argles TW, Carter A, Kelley SP, Whitehouse MJ, Lonergan L. 2003. Exhumation of the Ronda peridotite and its crustal envelope: Constraints from thermal modelling of a P-T-time array. Journal of the Geological Society 160: 655-676. https://doi.org/ 10.1144/0016-764902-108.

Précigout J, Gueydan F, Garrido CJ, Cogné N, Booth-Rea G. 2013. Deformation and exhumation of the Ronda peridotite (Spain). Tectonics 32: 1011-1025. https://doi.org/10.1002/tect.20062.

Puga E. 1990. The Betic Ophiolitic Association (southeastern Spain). Ofioliti 15: 97-117.

Puga E, Fanning CM, Nieto JM, Díaz de Federico A. 2005. New recrystallisation textures in zircons generated by ocean-floor and eclogite-facies metamorphism: A cathodoluminescence and U-Pb SHRIMP study with constraints from REE elements. The Canadian Mineralogist 43: 1349-1368. https://doi.org/10.2113/gscan min.43.1.183.

Reuber I, Michard A, Chalouan A, Juteau T, Jermoumi B. 1982. Structure and emplacement of the Alpine type peridotites from Beni Bousera, Rif, Morocco: A polyphase tectonic interpretation. Tectonophysics 82: 231-251. https://doi.org/10.1016/0040-1951 (82)90047-6.

Rodríguez-Cañero R, Jabaloy-Sánchez A, Navas-Parejo P, MartínAlgarra A. 2018. Linking Palaeozoic palaeogeography of the Betic Cordillera to the Variscan Iberian Massif: new insight through the first conodonts of the Nevado-Filábride Complex. International Journal of Earth Sciences 107: 1791-1806. https://doi.org/ 10.1007/s00531-017-1572-8.

Rossetti F, Faccenna C, Goffé B, et al. 2001. Alpine structural and metamorphic signature of the Sila Piccola massif nappe stack (Calabria, Italy): Insights for the tectonic evolution of the Calabrian arc. Tectonics 20: 112-133. https://doi.org/10.1029/ $2000 \mathrm{TC} 900027$

Rossetti F, Theye T, Lucci F, Bouybaouene ML, Dini A, Gerdes A, et al. 2010. Timing and modes of granite magmatism in the core of the Alboran Domain, Rif chain, northern Morocco: Implications for the Alpine evolution of the western Mediterranean. Tectonics 29. https://doi.org/10.1029/2009TC002487.

Rossetti F, Dini A, Lucci F, Bouybaouene ML, Faccenna C. 2013. Early Miocene strike-slip tectonics and granite emplacement in the Alboran Domain (Rif chain, Morocco): significance for the geodynamic evolution of western Mediterranean. Tectonophysics 608: 774-791. https://doi.org/10.1016/j.tecto.2013.08.002.

Rossetti F, Lucci F, Theye T, Bouybaouene ML, Gerdes A, Opitz J, et al. 2020. Hercynian anatexis in the envelope of the Beni Bousera 
peridotites (Alboran Domain, Morocco): Implications for the tectono-metamorphic evolution of the deep crustal roots of the Mediterranean region. Gondwana Res 83: 157-182. https://doi.org/ 10.1016/j.gr.2020.01.020.

Rossi P, Cocherie A, Fanning CM, Deloule É. 2006. Variscan to EoAlpine events recorded in European lower-crust zircons sampled from the French Massif Central and Corsica, France. Lithos 87: 235-260. https://doi.org/10.1016/j.lithos.2005.06.009.

Royden LH. 1993. Evolution of retreating subduction boundaries formed during continental collision. Tectonics 12: 629-638. https:// doi.org/10.1029/92TC02641.

Saddiqi O. 1988. Tectonique de la remontée du manteau: les péridotites des Beni Bousera et leur enveloppe métamorphique, Rif interne, Maroc. PhD thesis, Univ. Louis-Pasteur Strasbourg, $180 \mathrm{p}$.

Saddiqi O, Reuber I, Michard A. 1988. Sur la tectonique de dénudation du manteau infracontinental dans les Beni Bousera, Rif septentrional, Maroc. C R Acad Sci Paris 307(sér. II): 657-662.

Saddiqi O, Chalouan A, Farah A, Michard A. 2019. A forgotten marble zone on top of the Beni Bousera kinzigites (Internal Rif, Morocco); implications for the exhumation of the underlying peridotites and the regional tectonics. Workshop "Alboran Domain and Gibraltar Arc: geological research and natural hazards". Spain: Granada Univ.

Sánchez-Gómez M, Balanyá JC, Garcia-Dueñas V, Azañón JM. 2002. Intracrustal tectonic evolution of large lithosphere mantle slabs in the western end of the Mediterranean orogen (Gibraltar arc). $J$ Virtual Explor 8: 23-34.

Sánchez-Gómez M, García-Dueñas V, Muñoz M. 1995. Relations structurales entre les péridotites de Sierra Bermeja et les unités alpujarrides sous-jacentes (Benahavís, Ronda, Espagne). C R Acad Sci Paris 321(II): 885-892.

Sánchez-Navas A, García-Casco A, Mazzoli S, Martín-Algarra A. 2017. Polymetamorphism in the Alpujarride complex, Betic Cordillera, South Spain. J Geol 125: 637-657. https://doi.org/ 10.1086/693862.

Sánchez-Rodríguez L, Gebauer D. 2000. Mesozoic formation of pyroxenites and gabbros in the Ronda area (southern Spain), followed by Early Miocene subduction metamorphism and emplacement into the middle crust: $\mathrm{U}-\mathrm{Pb}$ sensitive high-resolution ion microprobe dating of zircon. Tectonophysics 316: 19-44. https://doi.org/10.1016/S0040-1951(99)00256-5.

Santamaria-Lopez A, Lanari P, Sanz de Galdeano C. 2019. Deciphering the tectonometamorphic evolution of the NevadoFilábride complex (Betic Cordillera, Spain) - A petrochronological study. Tectonophysics 767: 128-158.

Sanz de Galdeano C, López-Garrido AC, Andreo B. 1999. The stratigraphic and tectonic relationships of the Alpujarride and Malaguide complexes in the western Cordillera (Casares, prov. of Malaga, South Spain). C R Acad Sci Paris 328: 113-119.

Sanz de Galdeano C, Andreo B, García-Tortosa FJ, López-Garrido AC. 2001. The Triassic palaeogeographic transition between the Alpujarride and Malaguide complexes. Betic-Rif Internal Zone (S Spain, N Morocco). Palaeogeogr Palaeoclim Palaeoecol 167: 157-173.

Sanz de Galdeano C, El Kadiri K, Simancas JF, et al. 2006. Paleogeographical reconstruction of the Malaguide-Ghomaride Complex (Internal Betic-Rifian Zone) based on Carboniferous granitoid pebble provenance. Geologica Carpathica 57: 327-336.

Sanz de Galdeano C, Ruiz-Cruz MD. 2016. Formaciones del Paleozoico superior al Triásico depositadas discordantes sobre las peridotitas de Ronda: Evidencia de su emplazamiento cortical durante el Herciniano. Estudios Geológicos 72(1): e043. https:// doi.org/10.3989/egeol.42046.368.
Schenk V. 1980. U-Pb and $\mathrm{Rb}-\mathrm{Sr}$ radiometric dates and their correlation with metamorphic events in the granulite-facies basement of the Serre, Southern Calabria (Italy). Contributions to Mineralogy and Petrology 73: 23-38.

Schenk V. 1984. Petrology of felsic granulites, metapelites, metabasics, ultramafics, and metacarbonates from Southern Calabria (Italy): Prograde metamorphism, uplift and cooling of a former lower crust. Journal of Petrology 25: 255-298.

Schmid SM, Kissling E, Diehl T, Van Hinsbergen DJJ, Molli G. 2017. Ivrea mantle wedge, arc of the Western Alps, and kinematic evolution of the Alps-Apennines orogenic system. Swiss Journal of Geosciences 110: 581-612. https://doi.org/10.1007/s00015-0160237-0.

Seymour NM, Stockli DF, Beltrando M, Smye AJ. 2016. Tracing the thermal evolution of the Corsican lower crust during Tethyan rifting. Tectonics 35: 2439-2466. https://doi.org/10.1002/ 2016 TC004178.

Soulaimani A, Ouanaimi H, Saddiqi O, Baidder L, Michard A. 2018. The Anti-Atlas Pan-African belt (Morocco): overview and pending questions. C R Geosci 350: 279-288.

Spakman W, Wortel MJR. 2004. A Tomographic View on Western Mediterranean Geodynamics. In: Cavazza W, et al. eds. The TRANSMED Atlas. The Mediterranean Region from Crust to Mantle. Berlin: Springer Verlag, pp. 31-52. https://doi.org/ 10.1007/978-3-642-18919-7 2.

Suter G. 1980. Carte structurale du Rif au 1/500.000. Notes et Mémoires du Service géologique du Maroc 245b.

Trümpy R. 1973. Situation au Trias, in Colloque Action Thématique Programmée INAG, 21 fév.-04 mars 1973 Tanger-Ronda. Bull Soc Géol Fr 7(15): 160-190.

Tubía JM, Cuevas J, Esteban JJ. 2012. Localization of deformation and kinematic shift during the hot emplacement of the Ronda peridotites (Betic Cordilleras, southern Spain). Journal of Structural Geology 50: 148-160. https://doi.org/10.1016/j.jsg.2012.06.010.

Van Hinsbergen DJJ, Vissers RL, Spakman W. 2014. Origin and consequences of western Mediterranean subduction, rollback, and slab segmentation. Tectonics 33: 393e419.

Varas-Reus MI, Garrido CJ, Marchesi C, Bosch D, Hidas K. 2018. Genesis of ultra-high pressure garnet pyroxenites in orogenic peridotites and its bearing on the compositional heterogeneity of the Earth's mantle. Geochimica et Cosmochimica Acta 232: 303 328 .

Vavra G, Schmid R, Gebauer D. 1999. Internal morphology, habit and $\mathrm{U}-\mathrm{Th}-\mathrm{Pb}$ microanalysis of amphibolite-to-granulite facies zircons: Geochronology of the Ivrea Zone (Southern Alps). Contributions to Mineralogy and Petrology 134: 380-404. https://doi.org/ 10.1007/s004100050492.

Vidal O, Goffé B, Bousquet R, Parra T. 1999. Calibration and testing of an empirical chloritoid-chlorite thermometer and thermodynamic data for daphnite. J Metamorph Geol 10: 603-614.

Vitale S, Ciarcia S. 2013. Tectono-stratigraphic and kinematic evolution of the southern Apennines/Calabria-Peloritani Terrane system (Italy). Tectonophysics 583: 164-182. https://doi.org/ 10.1016/j.tecto.2012.11.004.

Whitney DL, Evans BW. 2010. Abbreviations for names of rockforming minerals. American Mineralogist 95: 185-187. https://doi. org/10.2138/am.2010.3371.

Wildi W, Nold M, Uttinger J. 1977. La Dorsale calcaire entre Tétouan et Assifane (Rif interne, Maroc). Eclogae Geol Helv 70: 371-415.

Youbi N, Gaggero L, Assafar H, et al. 2018. U-Pb Zircon Geochronological and Petrologic Constraints on the Post-Colli- 
sional Variscan Volcanism of the Khenifra Basin (Western Meseta, Morocco). In: 2nd International Congress on Permian and Triassic Stratigraphic and Petrogenetic Implications 53-54. Casablanca 25th-27th April 2018, Abstract Book.

Yuan S, Neubauer F, et al. 2020. Widespread Permian granite magmatism in Lower Austroalpine units: significance for Permian rifting in the Eastern Alps. Swiss J Geosci 113: 18. https://doi.org/ 10.1186/s00015-020-00371-5.

Zeck HP, Whitehouse MJ. 1999. Hercynian, Pan-African, Proterozoic and Archean ion-microprobe zircon ages for a Betic-Rif core complex, Alpine belt, W Mediterranean - Consequences for its
P-T-t path. Contributions to Mineralogy and Petrology 134: 134 149. https://doi.org/10.1007/s004100050474.

Zeck HP, Whitehouse MJ. 2002. Repeated age resetting in zircons from Hercynian-Alpine polymetamorphic schists (Betic-Rif tectonic belt, S. Spain)-A U-Th-Pb ion microprobe study. Chemical Geology 182: 275-292. https://doi.org/10.1016/S0009-2541(01) 00296-0.

Zouicha A, Voigt S, Saber H, Marchetti L, Hminna A, El Attari A, et al. 2021. First record of Permian continental trace fossils in the Jebilet massif, Morocco. J Afr Earth Sci 173: 104015.

Cite this article as: Farah A, Michard A, Saddiqi O, Chalouan A, Chopin C, Montero P, Corsini M, Bea F. 2021. The Beni Bousera marbles, record of a Triassic-Early Jurassic hyperextended margin in the Alpujarrides-Sebtides units (Rif belt, Morocco), BSGF - Earth Sciences Bulletin 192: 26. 